University of Nebraska - Lincoln

DigitalCommons@University of Nebraska - Lincoln

Agronomy \& Horticulture -- Faculty Publications

Agronomy and Horticulture Department

2020

\title{
Quantifying On-Farm Nitrous Oxide Emission Reductions in Food Supply Chains
}

\author{
A.J. Eagle \\ E. McLellan \\ E.M. Brawner \\ M.H. Chantigny \\ Eric A. Davidson
}

See next page for additional authors

Follow this and additional works at: https://digitalcommons.unl.edu/agronomyfacpub

Part of the Agricultural Science Commons, Agriculture Commons, Agronomy and Crop Sciences Commons, Botany Commons, Horticulture Commons, Other Plant Sciences Commons, and the Plant Biology Commons

This Article is brought to you for free and open access by the Agronomy and Horticulture Department at DigitalCommons@University of Nebraska - Lincoln. It has been accepted for inclusion in Agronomy \& Horticulture -Faculty Publications by an authorized administrator of DigitalCommons@University of Nebraska - Lincoln. 


\section{Authors}

A.J. Eagle, E. McLellan, E.M. Brawner, M.H. Chantigny, Eric A. Davidson, J.B. Dickey, Bruce A. Linquist, T.M. Maaz, D.E. Pelster, Cameron M. Pittelkow, C. van Kessel, T.J. Vyn, and K. G. Cassman 


\section{Earth's Future}

\section{RESEARCH ARTICLE \\ 10.1029/2020EF001504 \\ Quantifying On-Farm Nitrous Oxide Emission Reductions in Food Supply Chains}

\author{
Special Section: \\ Quantifying Nutrient Budgets \\ for Sustainable Nutrient \\ Management
}

Key Points:

- Nitrogen balance is a robust indicator of nitrous oxide emissions from agricultural cropland

- Food-supply-chain companies and others can scale up field-level $\mathrm{N}$ balance values to measure progress toward sustainability goals over time

- The relationship between $\mathrm{N}$ balance and $\mathrm{N}_{2} \mathrm{O}$ emissions is nonlinear, so the greatest benefit will come from reducing high field-scale $\mathrm{N}$ balances

Supporting Information:

- Supporting Information S1

- Table SI

- Table S2

- Table S3

Correspondence to:

A. J. Eagle,

aeagle@edf.org

Citation:

Eagle, A. J., McLellan, E. L., Brawner, E. M., Chantigny, M. H., Davidson,

E. A., Dickey, J. B., et al. (2020) Quantifying on-farm nitrous oxide emission reductions in food supply chains. Earth's Future, 8, e2020EF001504. https://doi.org/ 10.1029/2020EF001504

Received 30 JAN 2020

Accepted 11 AUG 2020

Accepted article online 1 SEP 2020

†C. van Kessel and K. G. Cassman are Emeritus

Author Contributions:

Conceptualization: A. J. Eagle, E. L. McLellan, E. A. Davidson, B. A. Linquist, T. M. Maaz, C. M. Pittelkow, C. van Kessel, T. J. Vyn, K. G. Cassman (continued)

(c)2020 The Authors.

This is an open access article under the terms of the Creative Commons

Attribution License, which permits use, distribution and reproduction in any medium, provided the original work is properly cited.

\author{
A. J. Eagle ${ }^{1}$ (D) E. L. McLellan ${ }^{1}$, E. M. Brawner ${ }^{2}$, M. H. Chantigny ${ }^{3}$ (D) E. A. Davidson ${ }^{4}$ iD, \\ J. B. Dickey ${ }^{5}$, B. A. Linquist ${ }^{6}$ (D) T. M. Maaz $^{7}$ iD, D. E. Pelster ${ }^{3}$ iD, C. M. Pittelkow ${ }^{6}$ iD, \\ C. van Kessel ${ }^{6}$, T. J. Vyn ${ }^{8}$ iD, and K. G. Cassman' ${ }^{9}$ \\ ${ }^{1}$ Environmental Defense Fund, New York, NY, USA, ${ }^{2}$ Environmental Defense Fund (contractor), New York, NY, USA, \\ ${ }^{3}$ Quebec Research and Development Center, Agriculture and Agri-Food Canada, Quebec, Canada, ${ }^{4}$ University of \\ Maryland Center for Environmental Science, Cambridge, MD, USA, ${ }^{5}$ PlanTierra LLC., Davis, CA, USA, ${ }^{6}$ Department of \\ Plant Sciences, University of California, Davis, Davis, CA, USA, ${ }^{7}$ Department of Tropical Plant and Soil Sciences, \\ University of Hawaii at Mānoa, Honolulu, HI, USA, ${ }^{8}$ Agronomy Department, Purdue University, West Lafayette, IN, \\ USA, ${ }^{9}$ Department of Agronomy and Horticulture, University of Nebraska-Lincoln, Lincoln, NE, USA
}

Abstract Reducing nitrous oxide $\left(\mathrm{N}_{2} \mathrm{O}\right)$ emissions from agriculture is critical to limiting future global warming. In response, a growing number of food retailers and manufacturers have committed to reducing $\mathrm{N}_{2} \mathrm{O}$ emissions from their vast networks of farmer suppliers by providing technical assistance and financial incentives. A key challenge for such companies is demonstrating that their efforts are leading to meaningful progress toward their climate mitigation commitments. We show that a simplified version of soil surface nitrogen $(\mathrm{N})$ balance-or partial $\mathrm{N}$ balance-the difference between $\mathrm{N}$ inputs to and outputs from a farm field (fertilizer $\mathrm{N}$ minus crop $\mathrm{N}$ ), is a robust indicator of direct $\mathrm{N}_{2} \mathrm{O}$ emissions from fields with maize and other major rainfed temperate-region crops. Furthermore, we present a generalized environmental model that will allow food-supply-chain companies to translate aggregated and anonymized changes in average $\mathrm{N}$ balance across their supplying farms into aggregated changes in $\mathrm{N}_{2} \mathrm{O}$ emissions. This research is an important first step, based on currently available science, in helping companies demonstrate the impact of their sustainability efforts.

Plain Language Summary As a powerful greenhouse gas, nitrous oxide that is emitted from agriculture contributes to climate change. Reductions in these emissions are not only possible-they are critical to addressing climate change. Food companies and others wanting to reduce nitrous oxide emissions in their food supply chains are looking for a way to show evidence of progress. Our research shows that a simple calculation of nitrogen $(\mathrm{N}$ ) balance in crop fields ( $\mathrm{N}$ in fertilizer minus $\mathrm{N}$ in the harvested crop) can be used as an indicator of nitrous oxide emissions. At the large scale, reducing high $\mathrm{N}$ balances will reduce overall emissions. We demonstrate the strong relationship between $\mathrm{N}$ balance and nitrous oxide emissions and show how this simple model can be used at scale to bring about positive environmental change.

\section{Introduction}

Agriculture is the dominant anthropogenic global source of nitrous oxide $\left(\mathrm{N}_{2} \mathrm{O}\right)$ emissions (Tian et al., 2019), a long-lived greenhouse gas 265 times more powerful than carbon dioxide. Given the global imperative of limiting warming to $1.5^{\circ} \mathrm{C}$ (Masson-Delmotte et al., 2018) there is a desire for immediate action to reduce $\mathrm{N}_{2} \mathrm{O}$ and other greenhouse gas (GHG) emissions across large scales. $\mathrm{N}_{2} \mathrm{O}$ emissions from $\mathrm{N}$ fertilizer use, from both its manufacturing and field usage, dominate the GHG footprint of cereal-based food products (Goucher et al., 2017) and play an important role in the environmental impact of livestock production (Herrero et al., 2016). Food-supply-chain companies, with their influence on millions of hectares of crop production, could play an important role in reducing these emissions. As companies seek to reduce their overall GHG emissions (Krabbe et al., 2015), food suppliers using sustainability platforms such as Walmart's Project Gigaton look to translate improvements in agricultural management on their sourcing farms to changes (reductions) in $\mathrm{N}_{2} \mathrm{O}$ emissions.

Quantifying such changes is challenging. Nitrous oxide is most commonly produced in agricultural soils through the microbial processes of nitrification and denitrification (Butterbach-Bahl et al., 2013). Rapid response of these microbial processes to variations in the environmental factors governing $\mathrm{N}_{2} \mathrm{O}$ emissions 
Data curation: A. J. Eagle, E. M. Brawner, M. H. Chantigny, T. M. Maaz, D. E. Pelster

Formal analysis: A. J. Eagle, E. M.

Brawner, T. M. Maaz

Investigation: A. J. Eagle

Methodology: A. J. Eagle, E. L.

McLellan, K. G. Cassman

Project administration: A. J. Eagle,

E. L. McLellan

Resources: E. L. McLellan

Software: A. J. Eagle

Supervision: E. L. McLellan

Visualization: E. M. Brawner

Writing - original draft: A. J. Eagle, E.

L. McLellan

Writing - review \& editing: A. J.

Eagle, E. L. McLellan, E. M. Brawner,

M. H. Chantigny, E. A. Davidson, J. B.

Dickey, B. A. Linquist, T. M. Maaz, D.

E. Pelster, C. M. Pittelkow, C. van

Kessel, T. J. Vyn, K. G. Cassman gives rise to so-called "hot spots" and "hot moments" of $\mathrm{N}_{2} \mathrm{O}$ emissions (Groffman et al., 2009), whereby $\mathrm{N}_{2} \mathrm{O}$ production varies dramatically over short distances (meters) and time scales (hours). The existence of "hot spots" and "hot moments" creates high variability in measured emission values, complicating efforts to measure emissions and/or relate overall changes in $\mathrm{N}_{2} \mathrm{O}$ emissions to changes in agricultural management.

To date, relating agricultural management to $\mathrm{N}_{2} \mathrm{O}$ emissions has primarily relied on two broad approaches: (1) empirical relationships at global, national or regional scales between $\mathrm{N}_{2} \mathrm{O}$ emissions and $\mathrm{N}$ fertilizer rate (a partial measure of N availability; IPCC, 2006; Millar et al., 2010); and (2) complex biogeochemical models that attempt to simulate the impact of agricultural management practices on processes governing $\mathrm{N}_{2} \mathrm{O}$ emissions at field- or site-specific scales (e.g., American Carbon Registry, 2013). The primary challenge of reducing $\mathrm{N}_{2} \mathrm{O}$ emissions based on $\mathrm{N}$ fertilizer rate reductions is that it does not explicitly account for yield impacts or the efficiency of $\mathrm{N}$ fertilizer use, both of which are closely related to the potential for $\mathrm{N}$ losses. Multiple studies have shown that high-yielding maize systems can increase $\mathrm{N}$ use efficiency and reduce $\mathrm{N}$ losses, despite higher rates of $\mathrm{N}$ applied (Adviento-Borbe et al., 2007; Grassini \& Cassman, 2012). In contrast, focusing exclusively on fertilizer rate reductions risks jeopardizing yield, which makes it unattractive to farmers (Zhao et al., 2017). It also overlooks the potential role in reducing $\mathrm{N}_{2} \mathrm{O}$ emissions of specific fertilizer management practices (e.g., source, timing, placement; Snyder et al., 2009) and a broader set of farming practices that can improve $\mathrm{N}$ cycling in cropping systems (e.g., recycling $\mathrm{N}$ through cover cropping; Han et al., 2017). While practices that improve $\mathrm{N}$ use efficiency should allow for lower $\mathrm{N}$ application rates, there is no available evidence to suggest that farmers decrease $\mathrm{N}$ fertilizer rates when implementing practices that reduce $\mathrm{N}$ losses. One important consideration is that these practices can have higher costs, which places additional emphasis on avoiding yield losses to maintain economic profitability. Therefore, approaches to reduce $\mathrm{N}_{2} \mathrm{O}$ emissions should account for impacts on crop productivity and $\mathrm{N}$ use efficiency to enable realistic changes in farm management.

The challenge to the second approach is the need to parameterize, calibrate, and validate complex models for specific crops and regions to be sure that models are correctly simulating $\mathrm{N}_{2} \mathrm{O}$ emissions. Several dozen sitespecific input parameters potentially affect simulated emissions, but data on these parameters are not routinely collected on working farms. Likewise, the availability of field measurements to support model calibration and validation is quite limited across the range of crop-soil-climate-practice combinations likely to be of interest (Tonitto et al., 2018). Emissions responses to many practices have not yet been validated in these models (Tonitto et al., 2018), and research shows that some of these practices could generate different (and even opposite) emission responses within different regions or cropping systems (Venterea et al., 2012).

Here we present an approach to quantifying the impacts of management on direct soil $\mathrm{N}_{2} \mathrm{O}$ emissions that is uniquely aligned with food-supply-chain company needs. These needs include the ability to (1) estimate aggregated changes in $\mathrm{N}_{2} \mathrm{O}$ emissions across large $\left(>10,000 \mathrm{~km}^{2}\right)$ sourcing regions, based on readily available and anonymized field-level data from participating farmers; (2) capture the impact of a broad array of farm management practices on $\mathrm{N}_{2} \mathrm{O}$ emissions, recognizing that farmers want flexibility to tailor management to their specific conditions; and (3) easily quantify and aggregate emission reductions across a variety of cropping systems, soils and climate regions, ideally through use of a single (generalized) model. The challenge is to develop an $\mathrm{N}_{2} \mathrm{O}$ quantification approach that is robust at large scales, requires minimal input data, and aligns with farmers' interests in increased productivity and profitability. Direct soil emissions comprise about $80 \%$ of all food supply chain $\mathrm{N}_{2} \mathrm{O}$ emissions (EPA, 2019), and the opportunities for improved $\mathrm{N}$ management provide companies with options for programs that can reduce these emissions.

Our quantification approach is based on a field-level measure of the amount of N potentially available for $\mathrm{N}_{2} \mathrm{O}$ losses: $\mathrm{N}$ balance. We previously published a preliminary model for the relationship between $\mathrm{N}$ balance and $\mathrm{N}_{2} \mathrm{O}$ emissions for maize grown on silt loam soils and using inorganic $\mathrm{N}$ fertilizer (e.g., ammonia, urea, urea ammonium nitrate [UAN]) in the U.S. Corn Belt (McLellan et al., 2018). In the present paper, we test the validity of that preliminary model for explaining $\mathrm{N}$ balance- $\mathrm{N}_{2} \mathrm{O}$ relationships in systems that are more diverse in soil type, $\mathrm{N}$ source, crop and/or region.

Previous research suggests that $\mathrm{N}_{2} \mathrm{O}$ emissions are better predicted by the amount of $\mathrm{N}$ in excess of crop needs than by total $\mathrm{N}$ fertilizer rate (Chantigny et al., 1998; Omonode et al., 2017; van Groenigen et al., 2010). This excess or "surplus" N (van Eerdt \& Fong, 1998) is a measure of the extent to which N inputs remain in 
the crop field and are therefore vulnerable to loss by microbial processes such as denitrification and volatilization, or by physical processes such as leaching and runoff. Using mass-balance principles, this excess $\mathrm{N}$ can be quantified as the difference between $\mathrm{N}$ inputs to the crop field and $\mathrm{N}$ removed in harvested crops (including $\mathrm{N}$ removed in any harvested residue) at an annual or crop-cycle scale (whichever is shorter).

We therefore define $\mathrm{N}$ balance as the difference between $\mathrm{N}$ inputs to a field and $\mathrm{N}$ outputs from a field, calculated as follows:

$$
\text { NBalance }\left(\frac{\mathrm{kg} \mathrm{N}}{\mathrm{ha}}\right)=\text { TotalNApplied }\left(\frac{\mathrm{kg} \mathrm{N}}{\mathrm{ha}}\right)-\text { NRemoved }\left(\frac{\mathrm{kg} \mathrm{N}}{\mathrm{ha}}\right)
$$

Where TotalNApplied is equal to $\mathrm{N}$ from mineral fertilizer plus other $\mathrm{N}$ inputs (e.g., manure and other organic amendments, $\mathrm{N}$-fixing cash or cover crops, and irrigation water), and NRemoved is the $\mathrm{N}$ harvested with the crop and any residue removed (for harvested grain, this is calculated from crop yield and measured or estimated grain $\mathrm{N}$ concentration). For a major staple grain crop in a rainfed area, receiving only inorganic $\mathrm{N}$ fertilizer, the data needed to estimate $\mathrm{N}$ balance for a given field are limited to fertilizer $\mathrm{N}$ rate and yield, supplemented with estimates of grain $\mathrm{N}$ concentration. Measured grain $\mathrm{N}$ concentrations may not frequently be available from farmers and crop yield explains much more variability in grain $\mathrm{N}$ removal than does $\mathrm{N}$ concentration (Tenorio et al., 2019). Using literature-derived estimates of grain $\mathrm{N}$ concentrations would likely be sufficient for calculating $\mathrm{N}$ balance when aggregating over space and time. While sample testing may prove worthwhile for fine-tuning, the additional data collection could hamper participation rates. Thus, the calculation of $\mathrm{N}$ balance at field scale requires minimal data that are routinely gathered by farmers as part of their business operations.

Research shows that where $\mathrm{N}_{2} \mathrm{O}$ production is $\mathrm{N}$-limited, $\mathrm{N}_{2} \mathrm{O}$ emissions are relatively small and constant at negative or small $\mathrm{N}$ balances and increase more rapidly as $\mathrm{N}$ balance increases (Omonode et al., 2017; van Groenigen et al., 2010; Venterea et al., 2016). Here we propose a simple but robust methodology, based on the empirical relationship between $\mathrm{N}$ balance and $\mathrm{N}_{2} \mathrm{O}$ emissions, which can be used by food-supply-chain companies and others to quantify regional-scale aggregated changes in $\mathrm{N}_{2} \mathrm{O}$ emissions. We focus on the relationship between $\mathrm{N}$ balance and $\mathrm{N}_{2} \mathrm{O}$ emissions in typical rainfed cropping systems on the most widespread agricultural soils in temperate-climate crop-producing regions of the world. Such systems are the dominant source of grain, oilseed, and forage supply across regionally aggregated sourcing regions.

Our objective is to develop a generalized model that integrates variations in the highly site-specific relationship of $\mathrm{N}$ balance to $\mathrm{N}_{2} \mathrm{O}$ emissions across fields and years into a broader understanding. A widely applicable and straightforward model, based on biophysical understanding of the drivers of $\mathrm{N}_{2} \mathrm{O}$ emissions and easy to implement across tens of thousands of fields, will better enable food-supply-chain companies to track emissions reductions and thereby motivate greater emphasis on reducing $\mathrm{N}$ losses within the food supply chain. Our effort is therefore very different from, although intended to complement, prior work done to identify the relative impacts of an array of environmental factors (e.g., climate, soil texture) on $\mathrm{N}_{2} \mathrm{O}$ emissions (Butterbach-Bahl et al., 2013; Eagle et al., 2017), to create detailed $\mathrm{N}_{2} \mathrm{O}$ inventories at a wide range of spatial scales (Fitton et al., 2017), or to identify "hotspot" locations of very high $\mathrm{N}_{2} \mathrm{O}$ emissions (e. g., organic soils, flood-prone soil zones; Fisher et al., 2014; Pärn et al., 2018).

\section{Materials and Methods}

\subsection{Literature Survey and Database Compilation}

Data collection began with an expansion of the comprehensive literature search conducted for the preliminary model applied to maize on silt loam soils in the Corn Belt (McLellan et al., 2018). A Web of Science search located additional field studies and meta-analyses published since September 2016 and through May 2019, all reporting $\mathrm{N}_{2} \mathrm{O}$ emissions from maize and other crops. Potential studies referenced in these articles and in previous cropland $\mathrm{N}_{2} \mathrm{O}$ meta-analyses (Abalos et al., 2016; Bouwman, 1996; DeCock, 2014; Eagle et al., 2017; Kim et al., 2013; Kim \& Giltrap, 2017; Omonode et al., 2017; Rochette et al., 2018; Shcherbak et al., 2014; van Groenigen et al., 2010) were also retrieved and examined for relevant data. Selection criteria narrowed the studies to those most representative of typical annual field-crop systems in temperate regions. Atypical cropping systems and minor soil types with small production area are excluded from our analysis 


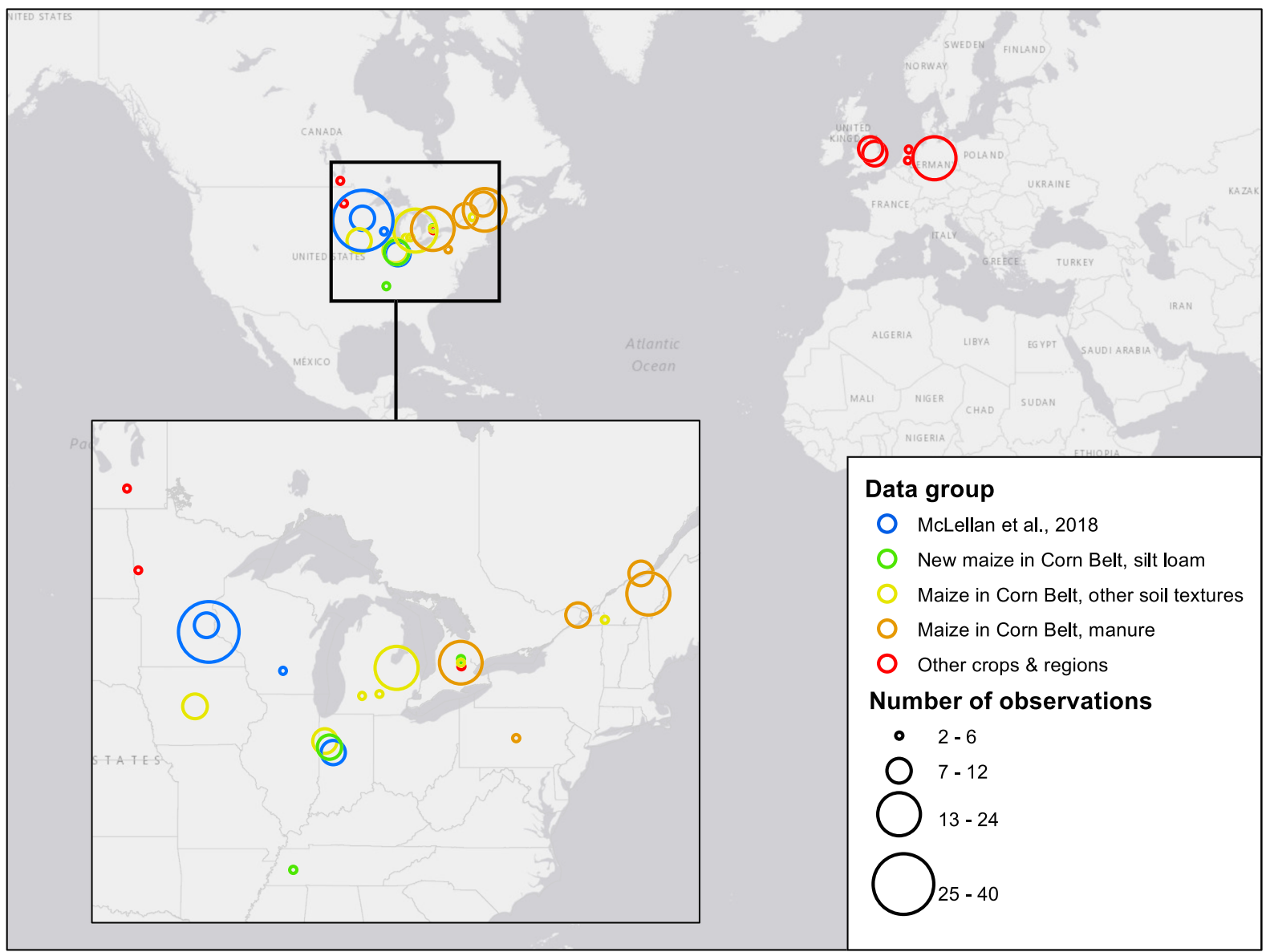

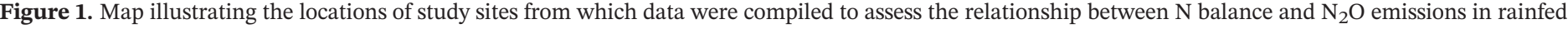
cropping systems. The inset shows the location of studies in the North American Corn Belt.

because they have limited influence on $\mathrm{N}_{2} \mathrm{O}$ emissions at the scale of large grain- and oilseed-sourcing regions. Soils in tropical regions, such as Oxisols in Brazil which have a high anion exchange capacity, may respond quite differently to $\mathrm{N}$ additions (Jankowski et al., 2018) and so are also excluded from our database. Likewise, $\mathrm{N}$ cycling in irrigated systems is likely to be quite different from that in rainfed systems (Trost et al., 2013); our survey was limited to rainfed crops.

The published data available for evaluating the $\mathrm{N}_{2} \mathrm{O}-\mathrm{N}$ balance relationship are dominated by studies on maize in the North American Corn Belt (region shown in Figure 1 inset panel). This is not surprising given the dominance of maize production in North American agriculture. Maize is grown on $26 \%$ of the total U.S. cropland area (39\% of cropland in Corn Belt states; United States Department of Agriculture, National Agricultural Statistics Service, 2019) and received an average of $44 \%$ of all $\mathrm{N}$ fertilizer used in the United States between 2006 and 2015 (United States Department of Agriculture, Economic Research Service, 2019). With maize production having such economic importance to agriculture, and associated fertilizer use having a large impact on regional $\mathrm{N}$ use and $\mathrm{N}$ losses, programs or interventions that target maize have significant potential to influence GHG emissions from crop production. However, recognizing that food companies are interested in a much wider array of crops than maize, we made particular effort to locate studies on other crops and in other regions.

With an emphasis on identifying studies of high experimental quality, we constrained data selection to those experiments that reported fertilizer or manure $\mathrm{N}$ application rate, crop yield or harvested $\mathrm{N}$ removed, and cumulative annual or growing season $\mathrm{N}_{2} \mathrm{O}$ emissions measured for a span of at least 70 days (detailed selection criteria in Table S1 in the supporting information). All studies reviewed that had shorter sampling time 
frames (55 days and less) were unlikely to capture peak emissions, began sampling midseason, or ceased sampling before emissions returned to baseline. For synthetic fertilizer observations, any plots known to receive manure or to be converted from a perennial in the previous two seasons were also excluded. Laboratory and greenhouse studies were also excluded. In order to best estimate the $\mathrm{N}_{2} \mathrm{O}$ emission impact of management changes on working farms where fertilizer $\mathrm{N}$ (or manure) is nearly always used for nonlegume crops, we excluded data from zero- $\mathrm{N}$ plots. This conveys the $\mathrm{N}_{2} \mathrm{O}$ response to $\mathrm{N}$ balance shifts within the range of typical $\mathrm{N}$ management practices and relevant to farmer experience. We further limited our data to experiments that intentionally varied $\mathrm{N}$ balance by monitoring at least two different nonzero $\mathrm{N}$ application rates. By eliminating experiments that used only a single rate, we reduce potential bias caused by overweighting the data within a limited range of $\mathrm{N}$ balance. This approach also ensured that the model data set represented a wide range of $\mathrm{N}$ balance values. For robustness tests, and for in-depth evaluation of the impact of factors other than $\mathrm{N}$ balance, we used an expanded data set that included zero-N observations and those from studies that measured $\mathrm{N}_{2} \mathrm{O}$ emissions from only one nonzero $\mathrm{N}$ application rate (see Tables $\mathrm{S} 2, \mathrm{~S} 3$, and S5). As a result of the selection criteria, both the model and expanded data sets excluded a number of studies (or portions thereof) that have been used by or mentioned in previous meta-analyses or syntheses (see Table S4).

Data were compiled as reported in published articles or supporting information, with some gaps (mostly crop yield and grain N) filled by data provided by study authors. For each site-year-treatment observation (most often the average of three to four replicates), data collected included $\mathrm{N}_{2} \mathrm{O}$ losses, crop yield, $\mathrm{N}$ fertilizer added, plus other management, soil, and environmental conditions. In order to maintain the simplest possible model, atmospheric N deposition was not considered. Deposition is rarely reported in these studies, and with a variety of time periods comprising the data set, obtaining accurate $\mathrm{N}$ deposition data for each site-year fell outside the project scope. In addition, inclusion would have minimal impact on identifying the most urgently needed on-farm changes (e.g., reducing very high $\mathrm{N}$ balances of 125 or $150 \mathrm{~kg} \mathrm{~N} \mathrm{ha}^{-1}$ to a more reasonable $50 \mathrm{~kg} \mathrm{~N} \mathrm{ha}^{-1}$ ). Crop yield values were converted to (or confirmed at) market-standard moisture content (e.g., 15.5\% for maize grain). For maize studies, we used reported grain $\mathrm{N}$ values where available; where not reported, we used the published International Plant Nutrition Institute (IPNI) values (e.g., $12 \mathrm{~kg} \mathrm{~N} \mathrm{Mg}^{-1}$ grain for maize at standard moisture content; IPNI, 2014; see Tenorio et al., 2019, for rationale). For studies on other crops, we only used data that reported crop $\mathrm{N}$ uptake.

Nitrogen balance is calculated in the basic system as the total fertilizer $\mathrm{N}$ added minus crop $\mathrm{N}$ removed. With increasing complexity, the inputs also included manure and the outputs include other harvested material such as straw or, in the case of forage, the full plant biomass. We categorized the data into five subsets, characterized by N source, soil type, and cropping system, as described below. Gaps in soil and weather characteristics were filled first with details from companion publications at the same site, and then from publicly available databases (see Table S6).

\subsection{Statistical Analyses}

In our analysis we determined the most appropriate relationship between $\mathrm{N}_{2} \mathrm{O}$ emissions and $\mathrm{N}$ balance on an area-scaled basis. While our previous model (McLellan et al., 2018) followed the work of van Groenigen et al. (2010) and others by using yield-scaled emissions, area-based emissions are more appropriate for the food-supply-chain context because of the climatic imperative to reduce absolute GHG emissions.

Because each data subset comprises a collection of studies that fit particular criteria, each subset has a unique statistical distribution of $\mathrm{N}$ balance, soil carbon (C), $\mathrm{N}_{2} \mathrm{O}$ monitoring period (e.g., summer vs. annual), long-term mean annual precipitation (MAP), and other factors affecting $\mathrm{N}$ cycling. This variability creates challenges in comparing the data across subsets. To address this challenge, we developed a hierarchical model using the STATA mixed command (StataCorp, 2019), grouping by both location and data subset. Grouping by location (research site) and data subset in the hierarchical model accommodates the nonindependent nature of these observations, going beyond a standard multivariate regression model by allowing possible response differences between groups (Qian et al., 2010; Woltman et al., 2012). Unless observations from the same research farm clearly came from the same experimental plots, we treated them as separate "locations" in the statistical model. Since a location group may include data from more than one research paper-especially with longer-running experiments-this approach differs somewhat from previous hierarchical-model meta-analyses that grouped by study or individual paper (e.g., Qian et al., 2010). The 
Table 1

Selected Characteristics Defining Five Data Subsets Used to Test Relationship Between $\mathrm{N}_{2} \mathrm{O}$ Emissions and $\mathrm{N}$ Balance

\begin{tabular}{|c|c|c|c|c|c|}
\hline Data subset $^{\mathrm{a}}$ & Crop(s) & Locations ${ }^{\mathrm{b}, \mathrm{c}}$ & Soil texture(s) & $\mathrm{N}$ source(s) & $\begin{array}{c}\mathrm{N}_{2} \mathrm{O} \text { monitoring } \\
\text { time frame, per } \\
\text { year }\end{array}$ \\
\hline $\mathrm{A}(n=69)$ & maize-grain & MN (72\%), IN (22\%), WI (6\%) & silt loam & $\begin{array}{l}\text { urea }(67 \%), \text { UAN (25\%), } \\
\text { SuperU (6\%), anhydrous } \\
\text { ammonia (AA; } 3 \%)\end{array}$ & $\begin{array}{c}<6 \text { months } \\
\quad(72 \%) \\
\geq 6 \text { months } \\
(28 \%)\end{array}$ \\
\hline $\mathrm{B}(n=24)$ & maize-grain & IN (67\%), ON (25\%), TN (8\%) & silt loam & $\begin{array}{c}\text { UAN (75\%), urea (17\%), } \\
\text { ammonium nitrate (AN; } \\
8 \%)\end{array}$ & $\begin{array}{l}<6 \text { months } \\
\quad(67 \%) \\
\geq 6 \text { months } \\
\quad(33 \%)\end{array}$ \\
\hline$C(n=64)$ & maize-grain & $\begin{array}{c}\text { MI (47\%), IA (19\%), IN (19\%), } \\
\text { ON (9\%), QC (6\%) }\end{array}$ & $\begin{array}{c}\text { loam }(67 \%) \text {, silty clay } \\
\text { loam }(19 \%) \text {, fine sandy } \\
\text { loam (8\%), clay loam } \\
(6 \%)\end{array}$ & $\begin{array}{l}\text { urea (47\%), UAN (34\%), } \\
\text { AA (13\%), AN (6\%) }\end{array}$ & $\begin{array}{c}<6 \text { months } \\
(61 \%), \\
\geq 6 \text { months(39\%) }\end{array}$ \\
\hline $\mathrm{D}(n=64)$ & $\begin{array}{l}\text { maize-grain } \\
(75 \%) \text { or silage } \\
(25 \%)\end{array}$ & $\mathrm{QC}(52 \%), \mathrm{ON}(48 \%)$ & $\begin{array}{l}\text { loam }(50 \%) \text {, clay }(42 \%) \\
\text { silt loam }(8 \%)\end{array}$ & $\begin{array}{c}\text { Manure - cattle (61\%), } \\
\text { hog }(39 \%)\end{array}$ & $\begin{array}{l}<6 \text { months } \\
\quad(45 \%) \\
\geq 6 \text { months } \\
\quad(55 \%)\end{array}$ \\
\hline $\mathrm{E}(n=65)$ & $\begin{array}{c}\text { wheat }(42 \%), \\
\text { canola }(14 \%), \\
\text { sugarbeet }(14 \%), \\
\text { silage maize }(12 \%), \\
\text { barley }(11 \%), \text { other } \\
(8 \%)\end{array}$ & $\begin{array}{c}\text { Germany (37\%), UK (29\%), Netherlands (12\%), } \\
\text { MB (9\%), MN (9\%), ON (3\%) }\end{array}$ & $\begin{array}{l}\text { silt loam (49\%), clay } \\
(15 \%) \text {, clay loam (8\%), } \\
\text { loamy sand (8\%), sandy } \\
\text { loam ( } 8 \%) \text {, sand }(6 \%), \\
\text { silty clay loam }(6 \%)\end{array}$ & $\begin{array}{l}\text { UAN (37\%), unspecified } \\
(29 \%), \text { urea (18\%), } \\
\text { calcium ammonium } \\
\text { nitrate (CAN; } 12 \%), \\
\text { polymer-coated urea } \\
\text { (PCU; } 3 \%)\end{array}$ & $\begin{array}{l}<6 \text { months } \\
\quad(48 \%), \\
\geq 6 \text { months } \\
\quad(52 \%)\end{array}$ \\
\hline
\end{tabular}

${ }^{a}$ Data sources: A: Osterholz et al. (2014), Smith et al. (2011), Venterea and Coulter (2015), Venterea et al. (2016); B: Burzaco et al. (2013), Congreves et al. (2017), Thornton and Valente (1996), Wagner-Riddle et al. (2007); C: Hernandez-Ramirez et al. (2009), Hoben et al. (2011), Iqbal et al. (2015), Omonode et al. (2015), Pelster et al. (2011), Roy et al. (2014); D: Abalos et al. (2016), Cambareri et al. (2017), Chantigny et al. (2010), Hernandez-Ramirez et al. (2009), Rochette et al. (2008), Schwager et al. (2016); E: Asgedom et al. (2014), Kaiser et al. (1998), Thapa et al. (2015), van Groenigen et al. (2004), Wagner-Riddle et al. (2007), Webb et al. (2004). ${ }^{b}$ Two-letter abbreviations correspond to postal system identifiers for U.S. states and Canadian provinces, with the exception of UK (United Kingdom). ${ }^{\mathrm{c}}$ Totals may not sum to $100 \%$ due to rounding off.

hierarchical models also address unbalanced data-in this case with between 2 and 40 observations per location-by weighting the contribution of observations to the overall effect according to group size and variance (i.e., the weighting factor decreases with more observations per group and with higher variance).

Data for cumulative $\mathrm{N}_{2} \mathrm{O}$ emissions were transformed (natural $\log$ ) and regressed against $\mathrm{N}$ balance, after being statistically adjusted to the mean soil $\mathrm{C}$ content, MAP, and $\mathrm{N}_{2} \mathrm{O}$ monitoring period. These three covariates consistently explained variability in $\mathrm{N}_{2} \mathrm{O}$ emissions within and between data subsets. The final multilevel hierarchical model included 286 observations from the five restricted data subsets, testing for differences between data subsets by allowing both the slope and intercept of the $\mathrm{N}$ balance- $\mathrm{N}_{2} \mathrm{O}$ relationship to vary between them.

Model specifications were varied to test for the impact of other explanatory variables, including long-term mean annual temperature, crop species, previous crop species, tillage system (conventional, conservation, or no-till), and fertilizer management (i.e., placement, source, and timing). With a larger number of observations, the expanded data set served as a robustness check on these relationships. Additional details on the testing and selection of confounding variables, between-group testing, and alternate model estimations are given in the supporting information.

\section{Data}

Figure 1 shows the locations of study sites in our final model, and Table 1 summarizes the characteristics of the five restricted data subsets. The first three subsets are limited to maize grown for grain using only inorganic $\mathrm{N}$ fertilizer. Subset A contains data used in our previous $\mathrm{N}$ Balance- $\mathrm{N}_{2} \mathrm{O}$ model study of maize systems on silt loam soils in the North American Corn Belt (McLellan et al., 2018). Subsets B and C of the data augment the Subset A database with more data from this silt-loam-soil system (Subset B) and data for maize on other soil textures (Subset C). Subset D adds observations from studies where maize-for either grain or 


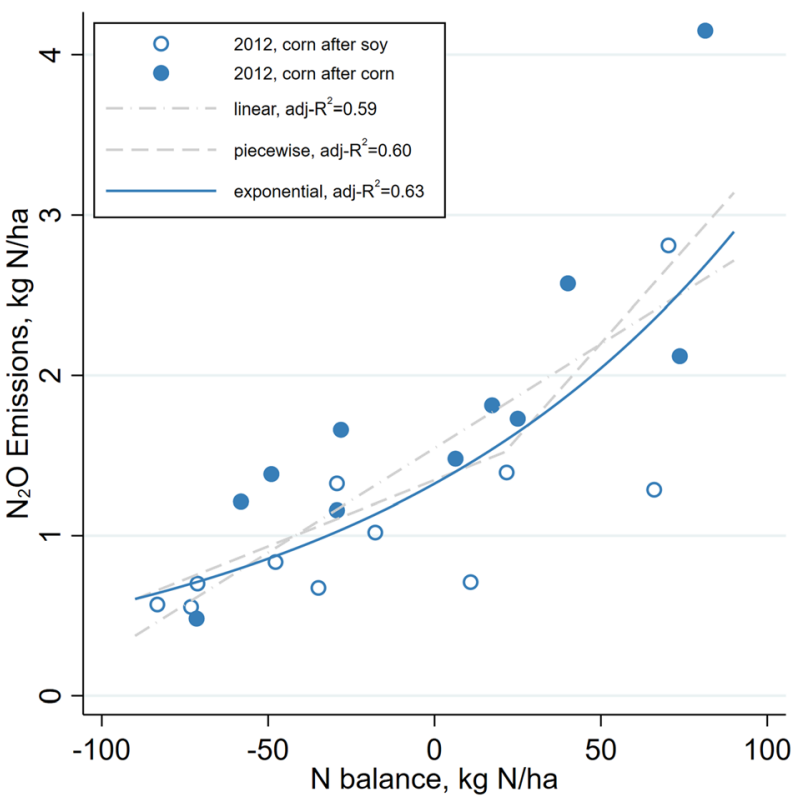

Figure 2. Example of $\mathrm{N}_{2} \mathrm{O}$ emissions related to $\mathrm{N}$ balance at a single siteyear with a wide range in $\mathrm{N}$ balance due to multiple $\mathrm{N}$ fertilizer rates. Drawn from data reported in Venterea and Coulter (2015), with fullfactorial data received from authors.

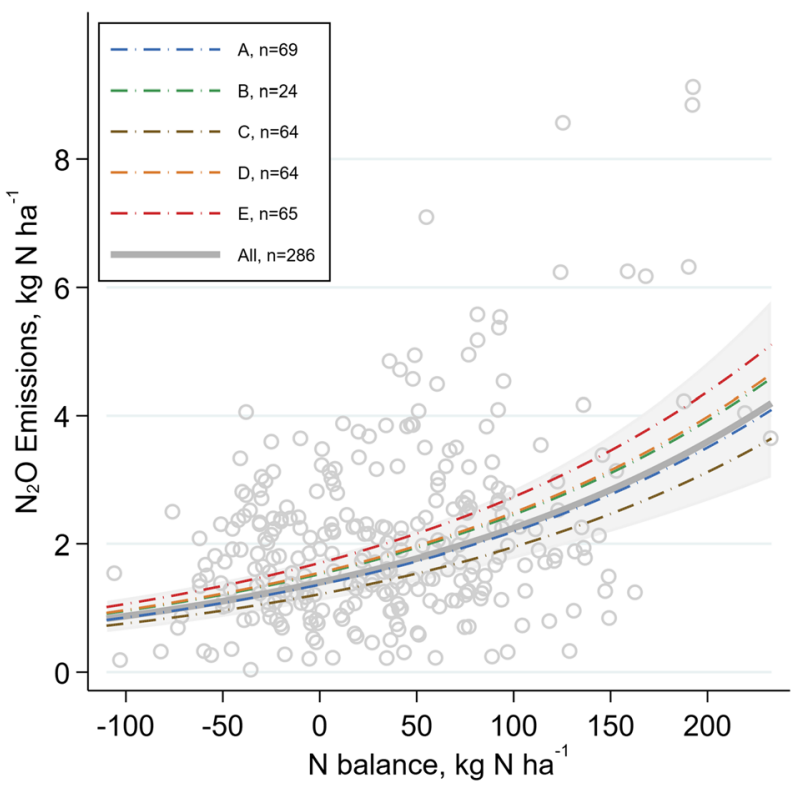

Figure 3. Generalized relationship (gray curve) between $\mathrm{N}_{2} \mathrm{O}$ emissions and $\mathrm{N}$ balance for all data. Line $\mathrm{A}$ is for the data subset of Corn Belt maize (CBM) on silt loam soils reported in McLellan et al. (2018), B is for CBM on other silt loam soils, $\mathrm{C}$ is for CBM on other soil textures, D is for $\mathrm{CBM}$ receiving manure as fertilizer, and $\mathrm{E}$ is for other crops and regions. Individual observations, adjusted to mean soil $\mathrm{C}, \mathrm{N}_{2} \mathrm{O}$ measurement time frame, and average yearly precipitation, are shown as open circles. To better show the majority of data points, two $\mathrm{N}_{2} \mathrm{O}$ observations with extreme measures are excluded from the graph (even though they are not excluded from the empirical model). silage-received manure, rather than inorganic fertilizer, as an $\mathrm{N}$ source. Grain $\mathrm{N}$ or $\mathrm{N}$ removed was reported (or otherwise made available from study authors) for 53\% of the 221 observations for Corn Belt maize (CBM). Data for other rainfed crops and regions across the globe comprise 65 observations (Subset E). Across the different subsets, the data represent variations in geography, as well as in environmental and management factors known to affect $\mathrm{N}$ cycling and crop production. The expanded data set that removed the requirement for multiple nonzero $\mathrm{N}$ fertilizer rates within each experiment totaled 805 observations, including 178 from other crops and regions (see Table S5 for details).

\section{Results}

\section{1. $\mathrm{N}$ Balance- $\mathrm{N}_{2} \mathrm{O}$ Relationships for an Individual Site-Year}

Figure 2 shows data on $\mathrm{N}$ balance and associated $\mathrm{N}_{2} \mathrm{O}$ emissions for one site-year (data from Venterea \& Coulter, 2015). This is the only site-year in our database with more than three nonzero $\mathrm{N}$ fertilizer rates that also reported actual grain $\mathrm{N}$ content. With multiple $\mathrm{N}$ fertilizer rates, treatments at this site provided a large range in measured $\mathrm{N}$ balance and allowed us to explore the impact of changes in $\mathrm{N}$ balance under otherwise constant conditions. Despite the scatter, a general relationship can be seen in which $\mathrm{N}_{2} \mathrm{O}$ emissions are relatively small at low $\mathrm{N}$ balance values but increase markedly at higher $\mathrm{N}$ balance values.

We tested a variety of $\mathrm{N}$ balance- $\mathrm{N}_{2} \mathrm{O}$ relationships-linear, exponential (log-linear) and piecewise (broken-stick or hockey-stick) regressionsand found that an exponential form most consistently fit the data for this site-year. Both the Akaike information criterion (AIC) and Bayesian information criterion (BIC) for piecewise and linear models were approximately double those for exponential models, with $\mathrm{R}^{2}$ values also higher for the exponential model (Figure 2).

\section{2. $\mathrm{N}$ Balance- $\mathrm{N}_{2} \mathrm{O}$ Relationships Across Soil Types, N Sources, and Cropping Systems}

An exponential form also fit best for the combined data set (Table S7). Moreover-and despite differences in soil types, regions, and $\mathrm{N}$ sources-the curvilinear shape of the relationship between $\mathrm{N}_{2} \mathrm{O}$ emissions and $\mathrm{N}$ balance was similar across all Corn Belt maize data sets (curves A-D in Figure 3). Likewise, the relationship between $\mathrm{N}_{2} \mathrm{O}$ emissions and $\mathrm{N}$ balance for other crops and regions (curve $\mathrm{E}$ in Figure 3) was consistent with the relationships for Corn Belt maize. Equally important, none of the relationships from individual data subsets were statistically different from one another or from the combined data set (note in Figure 3 that the curves for each data subset lie within the confidence interval for the combined data set). Therefore, we can identify a generalized relationship between $\mathrm{N}$ balance and $\mathrm{N}_{2} \mathrm{O}$ losses for a wide variety of cropping systems and regions, with the following equation:

$$
\mathrm{N}_{2} \mathrm{O}=\exp (0.339+0.0047 \times \mathrm{NBal})
$$

where $\mathrm{N}_{2} \mathrm{O}$ is annual cumulative $\mathrm{N}_{2} \mathrm{O}$ emissions and $\mathrm{NBal}$ is the annual $\mathrm{N}$ Balance, both in units of $\mathrm{kg} \mathrm{N} \mathrm{ha}^{-1}$ (or $\mathrm{lb} \mathrm{N}$ acre ${ }^{-1}$, if preferred).

The final model in Equation 2 includes adjustments for three different factors that consistently explained variability in the data-mean average 
annual precipitation ( $\mathrm{mm}$ ), soil $\mathrm{C}$ concentration ( $\mathrm{g} \mathrm{C} / \mathrm{kg}$ soil, surface horizon), and $\mathrm{N}_{2} \mathrm{O}$ measurement time frame (days). Given the data available, none of the other management and environmental variables tested had significant impacts on $\mathrm{N}_{2} \mathrm{O}$ emissions. On average, in the restricted model, $\mathrm{N}_{2} \mathrm{O}$ emissions increased by $9 \%$ for every additional $50 \mathrm{~mm}$ of annual precipitation, by $16 \%$ for every 30 extra days of sampling time, and by $3 \%$ for each $0.1 \%$ increment in soil $\mathrm{C}$ concentration (e.g., moving from 2.0 to $2.1 \%$ soil C). In comparison, emissions increased by $5 \%$ for each $10 \mathrm{~kg} \mathrm{~N} \mathrm{ha}^{-1}$ increase in $\mathrm{N}$ balance. The equation (and the $\mathrm{N}_{2} \mathrm{O}$ emission value for each observation in Figure 3) was adjusted to show the response of $\mathrm{N}_{2} \mathrm{O}$ emissions to changes in $\mathrm{N}$ balance with each of the three covariates set to their data set mean. This illustrates (as best as possible) how these data would appear without the variability caused by precipitation, sampling time frame and soil $\mathrm{C}$ concentration.

\section{Discussion}

The microbial processes that drive $\mathrm{N}_{2} \mathrm{O}$ production are highly sensitive to changes in environmental conditions, and high $\mathrm{N}_{2} \mathrm{O}$ fluxes can be brought on by rewetting of dry soils, drying of wet soils, thawing of frozen soils, temporary flooding and ponding, and increased availability of nitrogen substrates after fertilizer addition (Butterbach-Bahl et al., 2013). As a result, field-scale fluxes of $\mathrm{N}_{2} \mathrm{O}$ vary dramatically over hours, days and seasons. This temporal variation, coupled with the high spatial heterogeneity of soil physical, chemical and biological properties that influence microbial activity, leads to a large scatter in measured $\mathrm{N}_{2} \mathrm{O}$ emissions at individual sites (Chadwick et al., 2014; Reeves \& Wang, 2015; Wagner-Riddle et al., 2017), as illustrated in Figure 2, where there is considerable scatter even for a single site-year. Variability is also introduced by year over year weather impacts on crop productivity and $\mathrm{N}$ balance (Omonode \& Vyn, 2019) and by differences in sampling intensities, timing, and equipment in field experiments (Thies et al., 2019; Venterea et al., 2020).

\subsection{Shape of the Generalized $\mathrm{N}$ Balance- $\mathrm{N}_{2} \mathrm{O}$ Relationship}

Despite considerable scatter, the relationship between $\mathrm{N}$ balance and $\mathrm{N}_{2} \mathrm{O}$ emissions for the data shown in Figure 2 is still evident and of the exponential type to be expected based on N saturation theory (Gardner \& Drinkwater, 2009). When N inputs are small, “internal” sinks (i.e., crop uptake and short-term soil sinks) are larger than the $\mathrm{N}$ supply, and $\mathrm{N}$ losses are also small. Once crop uptake demand has been satisfied, the remaining $\mathrm{N}$ in excess of this amount is susceptible to environmental losses via leaching, runoff or gaseous loss pathways (the alternative fate of this nitrogen, incorporation into soil organic matter, appears to be minimal, at least in the Corn-Belt maize-soybean production systems that dominate our database; Verma et al., 2005). Hence, the rate of $\mathrm{N}$ loss accelerates as applied $\mathrm{N}$ exceeds crop $\mathrm{N}$ demand (i.e., once $\mathrm{N}$ balance exceeds a threshold value). Thus, for most cropping systems the relationship between $\mathrm{N}$ inputs, crop growth, and $\mathrm{N}$ losses is expected to be of an exponential or even a "hockey-stick" shape: with low losses at low N inputs (and low $\mathrm{N}$ balance), where much of the added $\mathrm{N}$ is taken up by the growing crop, and with $\mathrm{N}$ losses increasing more rapidly at higher $\mathrm{N}$ input values (and higher $\mathrm{N}$ balance) once crop uptake is saturated. While it is not possible to integrate economic optimum $\mathrm{N}$ rates into this analysis, this is an important area for future research. Both the "hockey-stick" and exponential shapes of Figure 2 are consistent with previous site-specific studies, such as the work of Broadbent and Carlton (1978), who measured both N uptake and losses for a large number and range of $\mathrm{N}$ fertilizer rates, allowing an analysis of $\mathrm{N}$ balance.

Given the multitude of factors that influence $\mathrm{N}_{2} \mathrm{O}$ emissions, it would not be surprising if the breakpoint in the "hockey-stick" curve (or the point in an exponential curve at which $\mathrm{N}_{2} \mathrm{O}$ emissions begin to dramatically increase) varied at a given site from year to year, and across sites in response to differences in soil type, cropping system and climate. In the supply-chain context, where the interest is in quantifying aggregated change across a variety of soils, climates, cropping systems, and management practices, it would be unrealistic to attempt to determine a site- and year-specific relationship between $\mathrm{N}$ balance and $\mathrm{N}_{2} \mathrm{O}$ emissions. It is of greater importance to determine an average relationship that integrates across multiple site-years of different exponential or "hockey-stick" curves, each of which may have different intercepts and different slopes at both high and low $\mathrm{N}$ balances. As shown in Figure 3, this average relationship takes on a shape best fit to an exponential curve, agreeing with other global meta-analyses that determined an exponential best fit of $\mathrm{N}_{2} \mathrm{O}$ emissions to whole-plant N surplus (van Groenigen et al., 2010) and to fertilizer rate (Shcherbak et al., 2014). While an exponential relationship of $\mathrm{N}_{2} \mathrm{O}$ to inputs tends to be more common than a linear one, Kim 
et al. (2013) hypothesized (but were unable to confirm) that the form may depend somewhat on whether these microbial-mediated emissions were limited more by available $\mathrm{N}$ or $\mathrm{C}$.

\subsection{Applicability to Rainfed Cropping Systems}

Of note in Figure 3 is the general congruence in shape and position of the curves for maize cropping systems (curves A-D) across a variety of soil types and N sources, suggesting that a single curve could represent all rainfed maize cropping systems in the North American Corn Belt. Perhaps even more intriguing is that the generalized curve for other crops and other regions (curve E) is also congruent with the various curves for Corn Belt maize. This similarity suggests that, rather than needing to develop separate relationships for each crop and soil type, climatic region and management practice, a single combined curve (represented by Equation 2) could capture the generalized relationship for all rainfed temperate-region crops on a global basis.

The $\mathrm{R}^{2}$ value for the $\mathrm{N}$ balance- $\mathrm{N}_{2} \mathrm{O}$ losses model (Equation 2 ) is 0.64 ; this value reflects the variable environments across which measurements were made, recalling that several environmental factors influence emissions even at small spatial and temporal scales. We believe that despite this modest $\mathrm{R}^{2}$ value, our model is sufficiently robust when used to estimate $\mathrm{N}_{2} \mathrm{O}$ emissions (and changes in $\mathrm{N}_{2} \mathrm{O}$ emissions) at the scale of hundreds or thousands of fields, where the influence of extreme high or low values from individual fields will cancel each other out (Philibert et al., 2012). The model is not intended for precise quantification at the scale of an individual field, but for predicting the impact of aggregated management change(s) (i.e., changes in $\mathrm{N}$ balance values) across a large, regional, food supply chain. In this context, the most important aspect of the model is its ability to predict average emissions and changes in emissions resulting from a management change, for a group of fields from a given region or watershed, or in fields that provide maize or other crops for a specific grain elevator, feedlot, mill, or another type of large grain buyer. In such circumstances, it is most important that the model be unbiased (i.e., neither overestimating nor underestimating average $\mathrm{N}_{2} \mathrm{O}$ values).

Exceptions to the general relationship between $\mathrm{N}$ balance and $\mathrm{N}_{2} \mathrm{O}$ emissions presented in Figure 3 certainly exist, even within the United States. For example, researchers have measured extremely high $\mathrm{N}_{2} \mathrm{O}$ emissions from crops and pasture on histosols (peat or high-organic-matter soils), ranging upward of an order of magnitude greater than emissions from typical mineral soils (Duxbury et al., 1982; Velthof \& Oenema, 1995). Emissions much higher than the norm are also seen in heavily fertilized, irrigated vegetable crops (Duxbury et al., 1982) and in poorly drained, heavy clay soils (Gagnon et al., 2011; Rochette et al., 2008). While these situations represent a small proportion of total crop production area in the United States-histosols and clay soils comprise $1.1 \%$ and $2.8 \%$, respectively, of maize-producing cropland in the United States, and irrigated vegetables take up only $0.9 \%$ of total U.S. cropland-they may be of greater importance in other countries (Deng et al., 2012; He et al., 2007). From a global perspective, therefore, significant climate (GHG reduction) benefits may be realized by reducing emissions from these anomalous (by U.S. standards) situations. Initial model specifications limited to the other crops and regions data subset suggested that $\mathrm{N}_{2} \mathrm{O}$ emissions from maize were higher than those from other crops. However, this appeared to be an artifact of higher rainfall and wetter soils in maize-producing regions, since the trend disappeared upon removing observations from Mediterranean locations in Spain (which have both lower rainfall and $\mathrm{N}_{2} \mathrm{O}$ emissions; e.g., Abalos et al., 2013; Guardia et al., 2018; Huerfano et al., 2016). Therefore, with sufficient aggregation across a group of farms, the current general model provides accuracy sufficient to advise management change and document evidence of environmental benefit from interventions along the supply chain.

Having a science-based, generalized relationship like Equation 2 is of critical importance in the food-supplychain context, where a food processor or retailer is likely to be sourcing multiple ingredients and products, each being supplied from tens of thousands of individual fields. The generalized $\mathrm{N}$ balance- $\mathrm{N}_{2} \mathrm{O}$ model of Figure 3 and Equation 2 allows a food company to calculate the aggregate $\mathrm{N}_{2} \mathrm{O}$ emissions associated with the production of major annual food and forage crops over a large geographic area knowing only the mean $\mathrm{N}$ balance across participating fields as reported by aggregators, such as participating agritech software companies. For example, a company manufacturing breakfast cereal might need to be able to easily and robustly quantify the annual $\mathrm{N}_{2} \mathrm{O}$ emissions associated with, variously, oats produced in Minnesota, wheat produced in Washington, and maize produced in Iowa. They could use the generalized $\mathrm{N}$ balance- $\mathrm{N}_{2} \mathrm{O}$ model to do so 


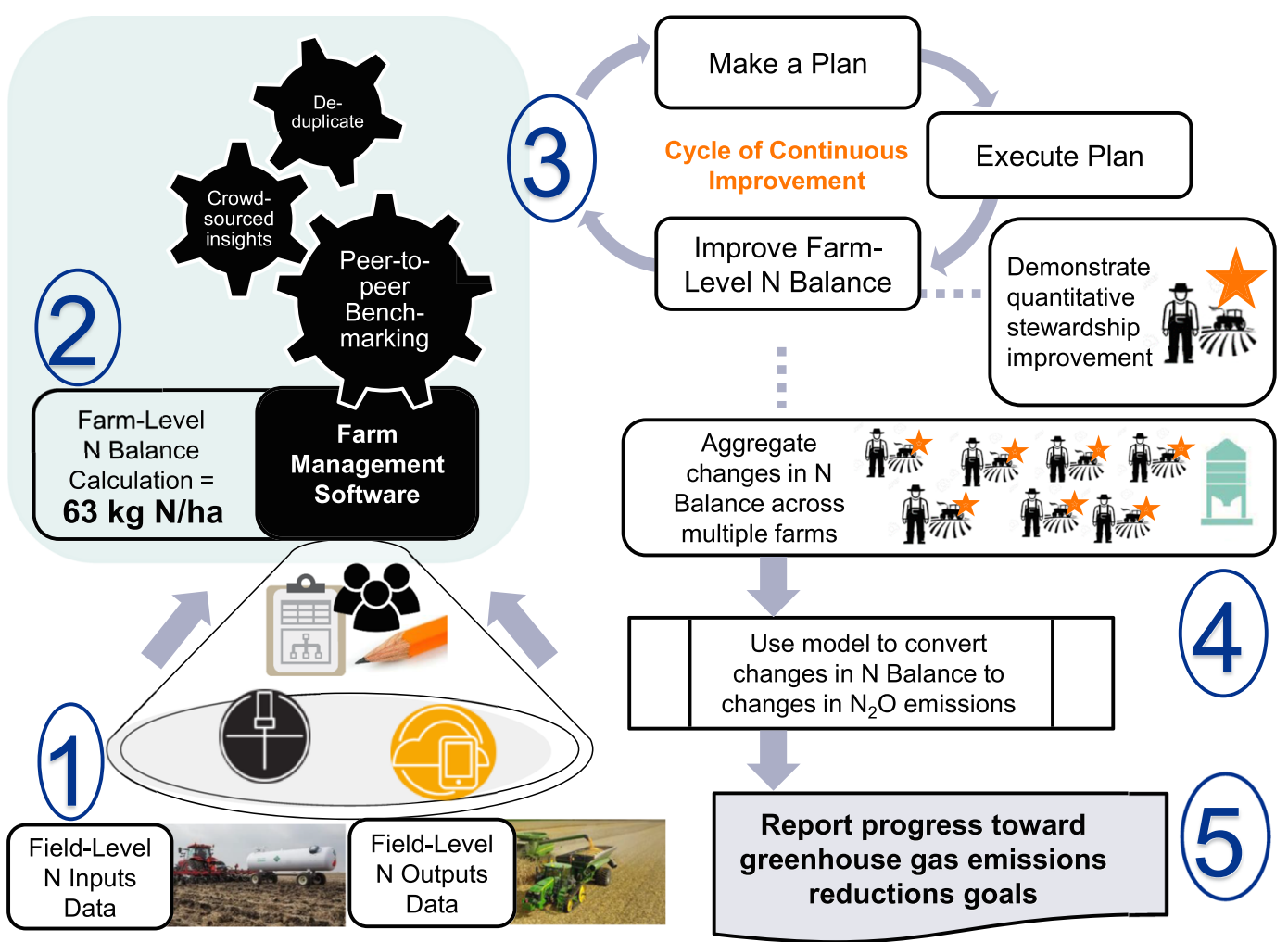

Figure 4. Example of $\mathrm{N}$ balance data flow from farm to food company that preserves farmer privacy while allowing important information to pass to both the farm and the purchasing food company. At Step 1, farmers and their advisors enter field-level data on $\mathrm{N}$ inputs and $\mathrm{N}$ outputs into farm management software, where $\mathrm{N}$ balance is calculated (Step 2). Peer-to-peer benchmarking of $\mathrm{N}$ balance values across farmer networks can stimulate individual farmers to plan for improvement (Step 3).Crowd-sourced insights on the relationship between $\mathrm{N}$ balance and various management practices, supported by data analytics (Step 2) can inform the continuous improvement plan (Step 3), leading over time to improvements in field- and farm-level $\mathrm{N}$ balance. Improvements in $\mathrm{N}$ balance over time allow individual farmers to demonstrate and quantify stewardship improvement. Aggregated changes in $\mathrm{N}$ balance across hundreds or thousands of fields can be translated into aggregate changes in $\mathrm{N}_{2} \mathrm{O}$ emissions using the generalized model described in this paper (Step 4), and food-supply-chain companies can report modeled reductions in $\mathrm{N}_{2} \mathrm{O}$ emissions to track progress toward their GHG reduction goals (Step 5).

without needing to know which crops are sourced from which fields, and without needing location-specific information on each field. Similarly, a meat-processing company could use our generalized model to quantify changes in aggregate $\mathrm{N}_{2} \mathrm{O}$ emissions following the provision of agronomic services or farmer incentives to a specific region, for various feed grains. While some differences in the $\mathrm{N}$ balance- $\mathrm{N}_{2} \mathrm{O}$ relationship are expected between crops, soil types, weather conditions, $\mathrm{N}$ sources and other management practices (e.g., tillage), only three factors (soil $\mathrm{C}$, precipitation, and monitoring period) consistently explained variability in the available data. Any precision gained in practice by applying different $\mathrm{N}$ balance- $\mathrm{N}_{2} \mathrm{O}$ relationships for each crop or management situation would need to be assessed in relation to the effort and cost required to collect and interpret the additional data that would be required. For more complete $\mathrm{N}_{2} \mathrm{O}$ accounting, indirect (off-site) emissions-on average less than $15 \%$ of $\mathrm{N}_{2} \mathrm{O}$ derived from agricultural soils (EPA, 2019) -could also be estimated by using IPCC Tier 1 emission factors applied to ammonia $\left(\mathrm{NH}_{3}\right)$ volatilization and nitrate $\left(\mathrm{NO}_{3}\right)$ leaching estimates (Tian et al., 2019). On the other hand, this too may not be worth the effort and cost.

Figure 4 shows the data flow pathway through the agri-food value chain, from farmer to food company, so as to maintain both data integrity and farmer privacy. We see crop consultants and farm software providers as being critical to this information management system: crop consultants facilitate high-quality data entry at the scale of the individual field; while software providers deliver low-effort solutions that balance traceability and anonymity, automate and standardize the calculation of the field's $\mathrm{N}$ balance value, calculate average $\mathrm{N}$ 
balance across different levels of desired aggregation, and automate the translation of an average aggregated $\mathrm{N}$ balance to aggregated $\mathrm{N}_{2} \mathrm{O}$ emissions. An individual food company working within a sourcing region can ensure emissions-accounting integrity and avoid the risk of artificially inflating the total amount of data collected-commonly referred to as double-counting_by (a) using a single information management system that ensures any given field boundary is genuinely unique among all others for which $\mathrm{N}$ balance is calculated, or (b) integrating multiple information management systems and utilizing a web-based service to identify and remove duplicate field boundaries for which $\mathrm{N}$ balance is calculated, The farm- or field-level results can then be shared with growers and their trusted advisors to stimulate and inform continuous improvement in $\mathrm{N}$ management, while aggregated, anonymized results can be provided further up the supply chain to help companies track the impact of their efforts.

From an implementation standpoint, important details will need to be considered and standardized across different food supply chains to ensure consistency among public claims of reduced $\mathrm{N}_{2} \mathrm{O}$ emissions. For example, a company would need to demonstrate an aggregated reduction in $\mathrm{N}$ balance across its supplying farms over a period of time. A multiyear moving average would be needed to smooth out the data and identify the baseline plus any trending change over time (suggesting that several years of data would be needed before making credible claims of emissions reductions). In addition to demonstrating $\mathrm{N}$ balance changes in the supplying region or group, a company may need to show evidence of their intervention in the system (e.g., incentives, changes in purchasing, service provision), to claim responsibility for said change.

\section{Conclusions}

In conclusion, we present a methodology for quantifying regional $\mathrm{N}_{2} \mathrm{O}$ emissions from cropping systems based on $\mathrm{N}$ balance, centered on a generalized relationship between $\mathrm{N}$ balance and $\mathrm{N}_{2} \mathrm{O}$ emissions across a wide variety of soils, climates, and cropping systems (Equation 2). We emphasize $\mathrm{N}$ balance over $\mathrm{N}$ fertilizer rate because it (i) better conforms to theoretical relationships between $\mathrm{N}$ application, crop growth, and $\mathrm{N}$ losses, (ii) has been shown by others to outperform $\mathrm{N}$ fertilizer rate as a predictor of $\mathrm{N}_{2} \mathrm{O}$ emissions, and (iii) is more acceptable to farmers, whose business and stewardship interests tend to be aligned with improving $\mathrm{N}$ balance. As an environmental risk metric, $\mathrm{N}$ balance also serves as an indicator of farm productivity, resource-use efficiency, and profitability, providing a useful measure of overall sustainability. In addition, focusing on the $\mathrm{N}$ balance outcome allows farmers to experiment with an array of conservation and nutrient-management practices to determine what works best for their particular location and cropping system.

We outline how the relationship between $\mathrm{N}$ balance and $\mathrm{N}_{2} \mathrm{O}$ emissions can serve as the foundation for a practical, data-driven approach to achieve meaningful $\mathrm{N}_{2} \mathrm{O}$ mitigation in agriculture. Food-supply-chain companies, farmers, and advisors can work with agricultural software providers to aggregate and analyze field-level N-balance data, giving farmers insights into opportunities to reduce $\mathrm{N}$ losses from their cropping systems, while enabling companies to quantify the environmental outcomes of their efforts to reduce $\mathrm{N}_{2} \mathrm{O}$ emissions. Ongoing support for field research will still be necessary to measure $\mathrm{N}_{2} \mathrm{O}$ emissions and develop a better, more site-specific understanding of changes in $\mathrm{N}$ balance associated with improved genetics, $4 \mathrm{R}$ nutrient stewardship, and other management practices, and to confirm the generalizability of the model to other crops and regions. There is a key need for additional field data on $\mathrm{N}_{2} \mathrm{O}$ emissions associated with other cropping systems - in experiments that intentionally vary $\mathrm{N}$ balance and report complete $\mathrm{N}$ uptake and removal as well as management details_-as these data are very poorly represented in the current literature. Nevertheless, our results will enable companies to quantify supply-chain emissions in the near term, which is a critical step in helping companies move forward with setting GHG reduction targets across large production regions. Such efforts will help corporate leaders demonstrate the role that the private sector can play in stabilizing global warming (Doda et al., 2016).

\section{Conflict of Interest}

We are not aware of any real or perceived financial conflicts of interests for any of the authors, nor any other affiliations for authors that may be perceived as having a conflict of interest with respect to the results of this paper. 


\section{Data Availability Statement}

Data used in the meta-analysis modeling are available in the Purdue University Research Repository (https://doi.org/10.4231/DFB0-F030).

\section{References}

\section{Acknowledgments}

We would like to express appreciation for the thorough and helpful reviews and feedback provided by the Editor and two anonymous reviewers.

Abalos, D., Brown, S. E., Vanderzaag, A. C., Gordon, R. J., Dunfield, K. E., \& Wagner-Riddle, C. (2016). Micrometeorological measurements over 3 years reveal differences in $\mathrm{N}_{2} \mathrm{O}$ emissions between annual and perennial crops. Global Change Biology, 22(3), 1244-1255. https:// doi.org/10.1111/gcb.13137
Abalos, D., Jeffery, S., Drury, C. F., \& Wagner-Riddle, C. (2016). Improving fertilizer management in the US and Canada for $\mathrm{N}_{2} \mathrm{O}$ mitigation: Understanding potential positive and negative side-effects on corn yields. Agriculture, Ecosystems \& Environment, 221, $214-221$. https://doi.org/10.1016/j.agee.2016.01.044

Abalos, D., Sanz-Cobena, A., Garcia-Torres, L., van Groenigen, J. W., \& Vallejo, A. (2013). Role of maize stover incorporation on nitrogen oxide emissions in a non-irrigated Mediterranean barley field. Plant and Soil, 364(1-2), 357-371. https://doi.org/10.1007/s11104-012$1,367-4$

Adviento-Borbe, M. A. A., Haddix, M. L., Binder, D. L., Walters, D. T., \& Dobermann, A. (2007). Soil greenhouse gas fluxes and global warming potential in four high-yielding maize systems. Global Change Biology, 13(9), 1972-1988. https://doi.org/10.1111/j.13652486.2007.01421.x

American Carbon Registry (2013). American Carbon Registry methodology for $\mathrm{N}_{2} \mathrm{O}$ emission reductions through changes in fertilizer management, Version 2.0. Little Rock, AR: Winrock International.

Asgedom, H., Tenuta, M., Flaten, D. N., Gao, X., \& Kebreab, E. (2014). Nitrous oxide emissions from a clay soil receiving granular urea formulations and dairy manure. Agronomy Journal, 106(2), 732-744. https://doi.org/10.2134/agronj2013.0096

Bouwman, A. F. (1996). Direct emission of nitrous oxide from agricultural soils. Nutrient Cycling in Agroecosystems, 46(1), 53-70. https:// doi.org/10.1007/bf00210224

Broadbent, F. E., \& Carlton, A. B. (1978). Field trials with isotopically labeled nitrogen fertilizer. In D. R. Nielsen \& J. G. MacDonald (Eds.), Nitrogen in the environment (pp. 1-41). New York, NY: Academic Press.

Burzaco, J. P., Smith, D. R., \& Vyn, T. J. (2013). Nitrous oxide emissions in Midwest US maize production vary widely with band-injected N fertilizer rates, timing and nitrapyrin presence. Environmental Research Letters, 8(3), 035031. https://doi.org/10.1088/1748-9,326/8/3/ 035031

Butterbach-Bahl, K., Baggs, E. M., Dannenmann, M., Kiese, R. \& Zechmeister-Boltenstern, S. (2013). Nitrous oxide emissions from soils: How well do we understand the processes and their controls? Philosophical Transactions of the Royal Society B: Biological Sciences, 368(1621), 20130122. https://doi.org/10.1098/rstb.2013.0122

Cambareri, G., Drury, C. F., Lauzon, J., Salas, W., \& Wagner-Riddle, C. (2017). Year-round nitrous oxide emissions as affected by timing and method of dairy manure application to corn. Soil Science Society of America Journal, 81(1), 166-178. https://doi.org/10.2136/ sssaj2016.05.0160

Chadwick, D. R., Cardenas, L., Misselbrook, T. H., Smith, K. A., Rees, R. M., Watson, C. J., et al. (2014). Optimizing chamber methods for measuring nitrous oxide emissions from plot-based agricultural experiments. European Journal of Soil Science, 65(2), 295-307. https:// doi.org/10.1111/ejss.12117

Chantigny, M. H., Prévost, D., Angers, D. A., Simard, R. R., \& Chalifour, F. P. (1998). Nitrous oxide production in soils cropped to corn with varying N fertilization. Canadian Journal of Soil Science, 78(4), 589-596. https://doi.org/10.4141/S98-009

Chantigny, M. H., Rochette, P., Angers, D. A., Bittman, S., Buckley, K., Masse, D., et al. (2010). Soil nitrous oxide emissions following bandincorporation of fertilizer nitrogen and swine manure. Journal of Environmental Quality, 39(5), 1545-1553. https://doi.org/10.2134/ jeq2009.0482

Congreves, K. A., Brown, S. E., Nemeth, D. D., Dunfield, K. E., \& Wagner-Riddle, C. (2017). Differences in field-scale $\mathrm{N}_{2} \mathrm{O}$ flux linked to crop residue removal under two tillage systems in cold climates. Global Change Biology Bioenergy, 9(4), 666-680. https://doi.org/10.1111/ gcbb. 12354

Decock, C. (2014). Mitigating nitrous oxide emissions from corn cropping systems in the midwestern US: Potential and data gaps. Environmental Science \& Technology, 48(8), 4247-4256. https://doi.org/10.1021/es4055324

Deng, J., Zhou, Z., Zheng, X., Liu, C., Yao, Z., Xie, B., et al. (2012). Annual emissions of nitrous oxide and nitric oxide from rice-wheat rotation and vegetable fields: A case study in the Tai-Lake region, China. Plant and Soil, 360(1-2), 37-53. https://doi.org/10.1007/ s11104-012-1,223-6

Doda, B., Gennaioli, C., Gouldson, A., Grover, D., \& Sullivan, R. (2016). Are corporate carbon management practices reducing corporate carbon emissions? Corporate Social Responsibility and Environmental Management, 23(5), 257-270. https://doi.org/10.1002/ csr.1369

Duxbury, J. M., Bouldin, D. R., Terry, R. E., \& Tate, R. L. (1982). Emissions of nitrous oxide from soils. Nature, 298(5873), 462-464. https:// doi.org/10.1038/298462a0

Eagle, A. J., Olander, L. P., Locklier, K. L., Heffernan, J. B., \& Bernhardt, E. S. (2017). Fertilizer management and environmental factors drive $\mathrm{N}_{2} \mathrm{O}$ and $\mathrm{NO}_{3}$ losses in corn: A meta-analysis. Soil Science Society of America Journal, 81(5), 1191-1202. https://doi.org/10.2136/ Sssaj2016.09.0281

EPA (2019). Inventory of U.S. greenhouse gas emissions and sinks, 1990-2017. Washington, DC: United States Environmental Protection Agency.

Fisher, K., Jacinthe, P. A., Vidon, P., Liu, X., \& Baker, M. E. (2014). Nitrous oxide emission from cropland and adjacent riparian buffers in contrasting hydrogeomorphic settings. Journal of Environmental Quality, 43(1), 338-348. https://doi.org/10.2134/jeq2013.06.0223

Fitton, N., Datta, A., Cloy, J. M., Rees, R. M., Topp, C. F. E., Bell, M. J., et al. (2017). Modeling spatial and inter-annual variations of nitrous oxide emissions from UK cropland and grasslands using DailyDayCent. Agriculture, Ecosystems \& Environment, 250, 1-11. https://doi. org/10.1016/j.agee.2017.08.032

Gagnon, B., Ziadi, N., Rochette, P., Chantigny, M. H., \& Angers, D. A. (2011). Fertilizer source influenced nitrous oxide emissions from a clay soil under corn. Soil Science Society of America Journal, 75(2), 595-604. https://doi.org/10.2136/sssaj2010.0212

Gardner, J. B., \& Drinkwater, L. E. (2009). The fate of nitrogen in grain cropping systems: a meta-analysis of ${ }^{15} \mathrm{~N}$ field experiments. Ecological Applications, 19(8), 2167-2184. https://doi.org/10.1890/08-1122.1 
Goucher, L., Bruce, R., Cameron, D. D., Koh, S. L., \& Horton, P. (2017). The environmental impact of fertilizer embodied in a wheat-tobread supply chain. Nature Plants, 3(3), 17012. https://doi.org/10.1038/nplants.2017.12

Grassini, P., \& Cassman, K. G. (2012). High-yield maize with large net energy yield and small global warming intensity. Proceedings of the National Academy of Sciences, 109(4), 1074-1079. https://doi.org/10.1073/pnas.1116364109

Groffman, P. M., Butterbach-Bahl, K., Fulweiler, R. W., Gold, A. J., Morse, J. L., Stander, E. K., et al. (2009). Challenges to incorporating spatially and temporally explicit phenomena (hotspots and hot moments) in denitrification models. Biogeochemistry, 93(1-2), 49-77. https://doi.org/10.1007/s10533-008-9,277-5

Guardia, G., Sanz-Cobena, A., Sanchez-Martín, L., Fuertes-Mendizábal, T., González-Murua, C., Álvarez, J. M., et al. (2018). Urea-based fertilization strategies to reduce yield-scaled $\mathrm{N}$ oxides and enhance bread-making quality in a rainfed Mediterranean wheat crop. Agriculture, Ecosystems \& Environment, 265, 421-431. https://doi.org/10.1016/j.agee.2018.06.033

Han, Z., Walter, M. T., \& Drinkwater, L. E. (2017). $\mathrm{N}_{2} \mathrm{O}$ emissions from grain cropping systems: A meta-analysis of the impacts of fertilizerbased and ecologically-based nutrient management strategies. Nutrient Cycling in Agroecosystems, 107(3), 335-355. https://doi.org/ 10.1007/s10705-017-9,836-z

He, F., Chen, Q., Jiang, R., Chen, X., \& Zhang, F. (2007). Yield and nitrogen balance of greenhouse tomato (Lycopersicum esculentum Mill.) with conventional and site-specific nitrogen management in northern China. Nutrient Cycling in Agroecosystems, 77(1), 1-14. https:// doi.org/10.1007/s10705-006-6,275-7

Hernandez-Ramirez, G., Brouder, S. M., Smith, D. R., \& Van Scoyoc, G. E. (2009). Greenhouse gas fluxes in an eastern corn belt soil: Weather, nitrogen source, and rotation. Journal of Environmental Quality, 38(3), 841-854. https://doi.org/10.2134/jeq2007.0565

Herrero, M., Henderson, B., Halvik, P., Thornton, P. K., Smith, P. S., Wirsenius, S., et al. (2016). Greenhouse gas mitigation potentials in the livestock sector. Nature Climate Change, 6(5), 452-461. https://doi.org/10.1038/nclimate2925

Hoben, J. P., Gehl, R. J., Millar, N., Grace, P. R., \& Robertson, G. P. (2011). Non-linear nitrous oxide $\left(\mathrm{N}_{2} \mathrm{O}\right)$ response to nitrogen fertilizer in on-farm corn crops of the U.S. Midwest. Global Change Biology, 17(2), 1140-1152. https://doi.org/10.1111/j.1365-2486.2010.02349.x

Huerfano, X., Fuertes-Mendizabal, T., Fernandez-Diez, K., Estavillo, J. M., Gonzalez-Murua, C., \& Menendez, S. (2016). The new nitrification inhibitor 3,4-dimethylpyrazole succinic (DMPSA) as an alternative to DMPP for reducing $\mathrm{N}_{2} \mathrm{O}$ emissions from wheat crops under humid Mediterranean conditions. European Journal of Agronomy, 80, 78-87. https://doi.org/10.1016/j.eja.2016.07.001

IPCC. (2006). $\mathrm{N}_{2} \mathrm{O}$ emissions from managed soils, and $\mathrm{CO}_{2}$ emissions from lime and urea application. In H. S. Eggleston, L. Buendia, K. Miwa, T. Ngara, \& K. Tanabe (Eds.), 2006 IPCC Guidelines for National Greenhouse Gas Inventories (Vol. 4, Ch. 11) Japan: IGES. https:// www.ipcc.ch/report/2006-ipcc-guidelines-for-national-greenhouse-gas-inventories/

IPNI. (2014). IPNI estimates of nutrient uptake and removal. Norcross, GA: International Plant Nutrition Institute. http://www.ipni.net/ article/IPNI-3296

Iqbal, J., Mitchell, D. C., Barker, D. W., Miguez, F., Sawyer, J. E., Pantoja, J., \& Castellano, M. J. (2015). Does nitrogen fertilizer application rate to corn affect nitrous oxide emissions from the rotated soybean crop? Journal of Environmental Quality, 44(3), 711-719. https://doi. org/10.2134/jeq2014.09.0378

Jankowski, K., Neill, C., Davidson, E. A., Macedo, M. N., Costa, C., Galford, G. L., et al. (2018). Deep soils modify environmental consequences of increased nitrogen fertilizer use in intensifying Amazon agriculture. Scientific Reports, 8, 13478. https://doi.org/10.1038/ s41598-018-31,175-1

Kaiser, E. A., Kohrs, K., Kucke, M., Schnug, E., Heinemeyer, O., \& Munch, J. C. (1998). Nitrous oxide release from arable soil: Importance of N-fertilization, crops and temporal variation. Soil Biology \& Biochemistry, 30(12), 1553-1563. https://doi.org/10.1016/s00380717(98)00036-4

Kim, D.-G., \& Giltrap, D. (2017). Determining optimum nitrogen input rate and optimum yield-scaled nitrous oxide emissions: Theory, field observations, usage, and limitations. Agriculture, Ecosystems \& Environment, 247, 371-378. https://doi.org/10.1016/j. agee.2017.07.003

Kim, D.-G., Hernandez-Ramirez, G., \& Giltrap, D. (2013). Linear and nonlinear dependency of direct nitrous oxide emissions on fertilizer nitrogen input: A meta-analysis. Agriculture, Ecosystems \& Environment, 168, 53-65. https://doi.org/10.1016/j.agee.2012.02.021

Krabbe, O., Linthorst, G., Blok, K., Crijns-Graus, W., Van Vuuren, D. P., Höhne, N., et al. (2015). Aligning corporate greenhouse-gas emissions targets with climate goals. Nature Climate Change, 5(12), 1057-1060. https://doi.org/10.1038/nclimate2770

Masson-Delmotte, V., Zhai, P., Pörtner, H. O., Roberts, D., Skea, J., Shukla, P. R., et al. (Eds.). (2018). Global warming of 1.5 ${ }^{\circ}$ C. An IPCC special report on the impacts of global warming of $1.5^{\circ} \mathrm{C}$ above pre-industrial levels and related global greenhouse gas emission pathways, in the context of strengthening the global response to the threat of climate change, sustainable development, and efforts to eradicate poverty. Retrieved from https://www.ipcc.ch/sr15/

McLellan, E. L., Cassman, K. G., Eagle, A. J., Woodbury, P. B., Sela, S., Tonitto, C., et al. (2018). The nitrogen balancing act: Tracking the environmental performance of food production. BioScience, 68(3), 194-203. https://doi.org/10.1093/biosci/bix164

Millar, N., Robertson, G. P., Grace, P. R., Gehl, R. J., \& Hoben, J. P. (2010). Nitrogen fertilizer management for nitrous oxide (N $\left.{ }_{2} \mathrm{O}\right)$ mitigation in intensive corn (maize) production: An emissions reduction protocol for US Midwest agriculture. Mitigation and Adaptation Strategies for Global Change, 15(2), 185-204. https://doi.org/10.1007/s11027-010-9,212-7

Omonode, R. A., Halvorson, A. D., Gagnon, B., \& Vyn, T. J. (2017). Achieving lower nitrogen balance and higher nitrogen recovery efficiency reduces nitrous oxide emissions in North America's maize cropping systems. Frontiers in Plant Science, 8, 1080. https://doi.org/ $10.3389 /$ fpls.2017.01080

Omonode, R. A., Kovacs, P., \& Vyn, T. J. (2015). Tillage and nitrogen rate effects on area- and yield-scaled nitrous oxide emissions from preplant anhydrous ammonia. Agronomy Journal, 107(2), 605-614. https://doi.org/10.2134/agronj14.0440

Omonode, R. A., \& Vyn, T. J. (2019). Tillage and nitrogen source impacts on relationships between nitrous oxide emission and nitrogen recovery efficiency in corn. Journal of Environmental Quality, 48(2), 421-429. https://doi.org/10.2134/jeq2018.05.0188

Osterholz, W. R., Kucharik, C. J., Hedtcke, J. L., \& Posner, J. L. (2014). Seasonal nitrous oxide and methane fluxes from grain- and foragebased production systems in Wisconsin, USA. Journal of Environmental Quality, 43(6), 1833-1843. https://doi.org/10.2134/ jeq2014.02.0077

Pärn, J., Verhoeven, J. T., Butterbach-Bahl, K., Dise, N. B., Ullah, S., Aasa, A., et al. (2018). Nitrogen-rich organic soils under warm welldrained conditions are global nitrous oxide emission hotspots. Nature Communications, 9(1), 1135. https://doi.org/10.1038/s41467-01803540-1

Pelster, D. E., Larouche, F., Rochette, P., Chantigny, M. H., Allaire, S., \& Angers, D. A. (2011). Nitrogen fertilization but not soil tillage affects nitrous oxide emissions from a clay loam soil under a maize-soybean rotation. Soil \& Tillage Research, 115, 16-26. https://doi.org/ 10.1016/j.still.2011.06.001 
Philibert, A., Loyce, C., \& Makowski, D. (2012). Quantifying uncertainties in $\mathrm{N}_{2} \mathrm{O}$ emission due to N fertilizer application in cultivated areas. Plos One, 7(11), e50950. https://doi.org/10.1371/journal.pone.0050950

Qian, S. S., Cuffney, T. F., Alameddine, I., McMahon, G., \& Reckhow, K. H. (2010). On the application of multilevel modeling in environmental and ecological studies. Ecology, 91(2), 355-361. https://doi.org/10.1890/09-1043.1

Reeves, S., \& Wang, W. (2015). Optimum sampling time and frequency for measuring $\mathrm{N}_{2} \mathrm{O}$ emissions from a rain-fed cereal cropping system. Science of the Total Environment, 530-531, 219-226. https://doi.org/10.1016/j.scitotenv.2015.05.117

Rochette, P., Angers, D. A., Chantigny, M. H., \& Bertrand, N. (2008). Nitrous oxide emissions respond differently to no-till in a loam and a heavy clay soil. Soil Science Society of America Journal, 72(5), 1363-1369. https://doi.org/10.2136/sssaj2007.0371

Rochette, P., Angers, D. A., Chantigny, M. H., Gagnon, B., \& Bertrand, N. (2008). $\mathrm{N}_{2} \mathrm{O}$ fluxes in soils of contrasting textures fertilized with liquid and solid dairy cattle manures. Canadian Journal of Soil Science, 88(2), 175-187. https://doi.org/10.4141/CJSS06016

Rochette, P., Liang, C., Pelster, D., Bergeron, O., Lemke, R., Kroebel, R., et al. (2018). Soil nitrous oxide emissions from agricultural soils in Canada: Exploring relationships with soil, crop and climatic variables. Agriculture, Ecosystems \& Environment, 254, 69-81. https://doi. org/10.1016/j.agee.2017.10.021

Roy, A. K., Wagner-Riddle, C., Deen, B., Lauzon, J., \& Bruulsema, T. (2014). Nitrogen application rate, timing and history effects on nitrous oxide emissions from corn (Zea mays L.). Canadian Journal of Soil Science, 94(4), 563-573. https://doi.org/10.4141/cjss2013-118

Schwager, E. A., VanderZaag, A. C., Wagner-Riddle, C., Crolla, A., Kinsley, C., \& Gregorich, E. (2016). Field nitrogen losses induced by application timing of digestate from dairy manure biogas production. Journal of Environmental Quality, 45(6), 1829-1837. https://doi. org/10.2134/jeq2016.04.0148

Shcherbak, I., Millar, N., \& Robertson, G. P. (2014). Global meta-analysis of the nonlinear response of soil nitrous oxide ( $\left.\mathrm{N}_{2} \mathrm{O}\right)$ emissions to fertilizer nitrogen. Proceedings of the National Academy of Sciences of the United States of America, 111(25), 9199-9204. https://doi.org/ $10.1073 /$ pnas.1322434111

Smith, D. R., Hernandez-Ramirez, G., Armstrong, S. D., Bucholtz, D. L., \& Stott, D. E. (2011). Fertilizer and tillage management impacts on non-carbon-dioxide greenhouse gas emissions. Soil Science Society of America Journal, 75(3), 1070-1082. https://doi.org/10.2136/ sssaj2009.0354

Snyder, C. S., Bruulsema, T. W., Jensen, T. L., \& Fixen, P. E. (2009). Review of greenhouse gas emissions from crop production systems and fertilizer management effects. Agriculture, Ecosystems \& Environment, 133(3-4), 247-266. https://doi.org/10.1016/j.agee.2009.04.021

StataCorp (2019). Stata Statistical Software: Release 16. College Station, TX: StataCorp LLC.

Tenorio, F. A., Eagle, A. J., McLellan, E. L., Cassman, K. G., Howard, R., Below, F. E., et al. (2019). Assessing variation in maize grain nitrogen concentration and its implications for estimating nitrogen balance in the US North Central region. Field Crops Research, 240, 185-193. https://doi.org/10.1016/j.fcr.2018.10.017

Thies, S., Bruggeman, S., Clay, S. A., Mishra, U., Hatfield, G., Kumar, S., \& Clay, D. E. (2019). Midmorning point sampling may not accurately represent nitrous oxide emissions following fertilizer applications. Soil Science Society of America Journal, 83(2), 339-347. https://doi.org/10.2136/sssaj2018.08.0313

Thapa, R., Chatterjee, A., Johnson, J. M. F., \& Awale, R. (2015). Stabilized nitrogen fertilizers and application rate influence nitrogen losses under rainfed spring wheat. Agronomy Journal, 107(5), 1885-1894. https://doi.org/10.2134/agronj15.0081

Thornton, F. C., \& Valente, R. J. (1996). Soil emissions of nitric oxide and nitrous oxide from no-till corn. Soil Science Society of America Journal, 60(4), 1127-1133. https://doi.org/10.2136/sssaj1996.03615995006000040024x

Tian, H., Yang, J., Xu, R., Lu, C., Canadell, J. G., Davidson, E. A., et al. (2019). Global soil nitrous oxide emissions since the preindustrial era estimated by an ensemble of terrestrial biosphere models: Magnitude, attribution, and uncertainty. Global Change Biology, 25(2), 640-659. https://doi.org/10.1111/gcb.14514

Tonitto, C., Woodbury, P. B., \& McLellan, E. L. (2018). Defining a best practice methodology for modeling the environmental performance of agriculture. Environmental Science \& Policy, 87, 64-73. https://doi.org/10.1016/j.envsci.2018.04.009

Trost, B., Prochnow, A., Drastig, K., Meyer-Aurich, A., Ellmer, F., \& Baumecker, M. (2013). Irrigation, soil organic carbon and $\mathrm{N}_{2} \mathrm{O}$ emissions. A review. Agronomy for Sustainable Development, 33(4), 733-749. https://doi.org/10.1007/s13593-013-0134-0

USDA ERS. (2019). Fertilizer use and price dataset. United States Department of Agriculture, Economic Research Service. Retrieved from https://www.ers.usda.gov/data-products/fertilizer-use-and-price/

USDA NASS. (2019). 2017 Census of Agriculture. United States Department of Agriculture, National Agricultural Statistics Service, Washington, DC. Retrieved from: www.nass.usda.gov/AgCensus

van Eerdt, M. M., \& Fong, P. K. N. (1998). The monitoring of nitrogen surpluses from agriculture. Environmental Pollution, 102(1), $227-233$. https://doi.org/10.1016/s0269-7491(98)80037-7

van Groenigen, J. W., Kasper, G. J., Velthof, G. L., van den Pol-van Dasselaar, A., \& Kuikman, P. J. (2004). Nitrous oxide emissions from silage maize fields under different mineral nitrogen fertilizer and slurry applications. Plant and Soil, 263(1-2), 101-111. https://doi.org/ 10.1023/b:plso.0000047729.43185.46

van Groenigen, J. W., Velthof, G. L., Oenema, O., van Groenigen, K. J., \& van Kessel, C. (2010). Towards an agronomic assessment of $\mathrm{N}_{2} \mathrm{O}$ emissions: A case study for arable crops. European Journal of Soil Science, 61(6), 903-913. https://doi.org/10.1111/j.13652389.2009.01217.x

Velthof, G. L., \& Oenema, O. (1995). Nitrous oxide fluxes from grassland in the Netherlands: II. Effects of soil type, nitrogen fertilizer application and grazing. European Journal of Soil Science, 46(4), 541-549. https://doi.org/10.1111/j.1365-2389.1995.tb01350.x

Venterea, R. T., \& Coulter, J. A. (2015). Split application of urea does not decrease and may increase nitrous oxide emissions in rainfed corn. Agronomy Journal, 107(1), 337-348. https://doi.org/10.2134/agronj14.0411

Venterea, R. T., Coulter, J. A., \& Dolan, M. S. (2016). Evaluation of intensive “4R" strategies for decreasing nitrous oxide emissions and nitrogen surplus in rainfed corn. Journal of Environmental Quality, 45(4), 1186-1195. https://doi.org/10.2134/jeq2016.01.0024

Venterea, R. T., Halvorson, A. D., Kitchen, N., Liebig, M. A., Cavigelli, M. A., Grosso, S. J. D., et al. (2012). Challenges and opportunities for mitigating nitrous oxide emissions from fertilized cropping systems. Frontiers in Ecology and the Environment, 10(10), 562-570. https:// doi.org/10.1890/120062

Venterea, R. T., Petersen, S. O., De Klein, C. A., Pedersen, A. R., Noble, A. D., Rees, R. M., et al. (2020). Global research alliance $\mathrm{N}_{2} \mathrm{O}$ chamber methodology guidelines: Flux calculations. Journal of Environmental Quality. https://doi.org/10.1002/jeq2.20118

Verma, S. B., Dobermann, A., Cassman, K. G., Walters, D. T., Knops, J. M., Arkebauer, T. J., et al. (2005). Annual carbon dioxide exchange in irrigated and rainfed maize-based agroecosystems. Agricultural and Forest Meteorology, 131(1), 77-96. https://doi.org/10.1016/j. agrformet.2005.05.003

Wagner-Riddle, C., Congreves, K. A., Abalos, D., Berg, A. A., Brown, S. E., Ambadan, J. T., et al. (2017). Globally important nitrous oxide emissions from croplands induced by freeze-thaw cycles. Nature Geoscience, 10(4), 279-283. https://doi.org/10.1038/ngeo2907 
Wagner-Riddle, C., Furon, A., McLaughlin, N. L., Lee, I., Barbeau, J., Jayasundara, S., et al. (2007). Intensive measurement of nitrous oxide emissions from a corn-soybean-wheat rotation under two contrasting management systems over 5 years. Global Change Biology, 13(8), 1722-1736. https://doi.org/10.1111/j.1365-2486.2007.01388.x

Webb, J., Ellis, S., Harrison, R., \& Thorman, R. (2004). Measurement of N fluxes and soil N in two arable soils in the UK. Plant and Soil, 260(1-2), 253-270. https://doi.org/10.1023/b:plso.0000030185.29220.79

Woltman, H., Feldstain, A., MacKay, J. C., \& Rocchi, M. (2012). An introduction to hierarchical linear modeling. Tutorials in Quantitative Methods for Psychology, 8(1), 52-69. https://doi.org/10.20982/tqmp.08.1.p052

Zhao, X., Nafziger, E. D., \& Pittelkow, C. M. (2017). Nitrogen rate strategies for reducing yield-scaled nitrous oxide emissions in maize. Environmental Research Letters, 12(12), 124006. https://doi.org/10.1088/1748-9,326/aa9007

\section{References From the Supporting Information}

Adviento-Borbe, M. A. A., Kaye, J. P., Bruns, M. A., McDaniel, M. D., McCoy, M., \& Harkcom, S. (2010). Soil greenhouse gas and ammonia emissions in long-term maize-based cropping systems. Soil Science Society of America Journal, 74(5), 1623-1634. https://doi.org/10.2136/ sssaj2009.0446

Almaraz, J. J., Mabood, F., Zhou, X., Madramootoo, C., Rochette, P., Ma, B.-L., \& Smith, D. L. (2009). Carbon dioxide and nitrous oxide fluxes in corn grown under two tillage systems in southwestern Quebec. Soil Science Society of America Journal, 73(1), 113-119. https:// doi.org/10.2136/sssaj2006.0371

Arango Argoti, M. A. (2013). Nitrous oxide emissions: Measurements in corn and simulations at field and regional scale (Doctoral dissertation). Manhattan, KS: Kansas State University.

Barton, L., Kiese, R., Gatter, D., Butterbach-Bahl, K., Buck, R., Hinz, C., \& Murphy, D. V. (2008). Nitrous oxide emissions from a cropped soil in a semi-arid climate. Global Change Biology, 14(1), 177-192. https://doi.org/10.1111/j.1365-2486.2007.01474.x

Bronson, K. F., Hunsaker, D. J., Williams, C. F., Thorp, K. R., Rockholt, S. M., del Grosso, S. J., et al. (2018). Nitrogen management affects nitrous oxide emissions under varying cotton irrigation systems in the Desert Southwest, USA. Journal of Environmental Quality, 47(1), 70-78. https://doi.org/10.2134/jeq2017.10.0389

Cambareri, G., Wagner-Riddle, C., Drury, C., Lauzon, J., \& Salas, W. (2017). Anaerobically digested dairy manure as an alternative nitrogen source to mitigate nitrous oxide emissions in fall-fertilized corn. Canadian Journal of Soil Science, 97(3), 439-451. https://doi.org/ 10.1139/cjss-2016-0097

Chantigny, M. H., Pelster, D. E., Perron, M.-H., Rochette, P., Angers, D. A., Parent, L.-É., et al. (2013). Nitrous oxide emissions from clayey soils amended with paper sludges and biosolids of separated pig slurry. Journal of Environmental Quality, 42(1), 30-39. https://doi.org/ $10.2134 /$ jeq2012.0196

Dell, C. J., Han, K., Bryant, R. B., \& Schmidt, J. P. (2014). Nitrous oxide emissions with enhanced efficiency nitrogen fertilizers in a rainfed system. Agronomy Journal, 106(2), 723-731. https://doi.org/10.2134/agronj2013.0108

Drury, C. F., Reynolds, W. D., Tan, C. S., McLaughlin, N. B., Yang, X. M., Calder, W., et al. (2014). Impacts of 49-51 years of fertilization and crop rotation on growing season nitrous oxide emissions, nitrogen uptake and corn yields. Canadian Journal of Soil Science, 94(3), 421-433. https://doi.org/10.4141/cjss2013-101

Drury, C. F., Reynolds, W. D., Tan, C. S., Welacky, T. W., Calder, W., \& McLaughlin, N. B. (2006). Emissions of nitrous oxide and carbon dioxide: Influence of tillage type and nitrogen placement depth. Soil Science Society of America Journal, 70(2), 570-581. https://doi.org/ $10.2136 /$ sssaj2005.0042

Drury, C. F., Reynolds, W. D., Yang, X. M., McLaughlin, N. B., Welacky, T. W., Calder, W., \& Grant, C. A. (2012). Nitrogen source, application time, and tillage effects on soil nitrous oxide emissions and corn grain yields. Soil Science Society of America Journal, 76(4), 1268-1279. https://doi.org/10.2136/sssaj2011.0249

Drury, C. F., Yang, X. M., Reynolds, W. D., Calder, W., Oloya, T. O., \& Woodley, A. L. (2017). Combining urease and nitrification inhibitors with incorporation reduces ammonia and nitrous oxide emissions and increases corn yields. Journal of Environmental Quality, 46(5), 939-949. https://doi.org/10.2134/jeq2017.03.0106

Fernández, F. G., Terry, R. E., \& Coronel, E. G. (2015). Nitrous oxide emissions from anhydrous ammonia, urea, and polymer-coated urea in Illinois cornfields. Journal of Environmental Quality, 44(2), 415-422. https://doi.org/10.2134/jeq2013.12.0496

Gao, X., Asgedom, H., Tenuta, M., \& Flaten, D. N. (2015). Enhanced efficiency urea sources and placement effects on nitrous oxide emissions. Agronomy Journal, 107(1), 265-277. https://doi.org/10.2134/agronj14.0213

Graham, R. F., Greer, K. D., Villamil, M. B., Nafziger, E. D., \& Pittelkow, C. M. (2018). Enhanced-efficiency fertilizer impacts on yieldscaled nitrous oxide emissions in maize. Soil Science Society of America Journal, 82(6), 1469-1481. https://doi.org/10.2136/ sssaj2018.05.0196

Huerfano, X., Estavillo, J. M., Fuertes-Mendizabal, T., Torralbo, F., Gonzalez-Murua, C., \& Menendez, S. (2018). DMPSA and DMPP equally reduce $\mathrm{N}_{2} \mathrm{O}$ emissions from a maize-ryegrass forage rotation under Atlantic climate conditions. Atmospheric Environment, 187, 255-265. https://doi.org/10.1016/j.atmosenv.2018.05.065

Lehman, R. M., \& Osborne, S. L. (2013). Greenhouse gas fluxes from no-till rotated corn in the upper Midwest. Agriculture, Ecosystems \& Environment, 170, 1-9. https://doi.org/10.1016/j.agee.2013.02.009

Maharjan, B., \& Venterea, R. T. (2013). Nitrite intensity explains $\mathrm{N}$ management effects on $\mathrm{N}_{2} \mathrm{O}$ emissions in maize. Soil Biology \& Biochemistry, 66, 229-238. https://doi.org/10.1016/j.soilbio.2013.07.015

Maharjan, B., \& Venterea, R. T. (2014). Anhydrous ammonia injection depth does not affect nitrous oxide emissions in a silt loam over two growing seasons. Journal of Environmental Quality, 43(5), 1527-1535. https://doi.org/10.2134/jeq2014.07.0292

Mendes Bastos, L. (2015). N fertilizer source and placement impacts nitrous oxide losses, grain yield, and $N$ use efficiency in no-till corn (Master's thesis). Manhattan, KS: Kansas State University.

Mueller, S. M., \& Vyn, T. J. (2016). Maize plant resilience to N stress and post-silking N capacity changes over time: A review. Frontiers in Plant Science, 7. https://doi.org/10.3389/fpls.2016.00053

Nangia, V., Sunohara, M. D., Topp, E., Gregorich, E. G., Drury, C. F., Gottschall, N., \& Lapen, D. R. (2013). Measuring and modeling the effects of drainage water management on soil greenhouse gas fluxes from corn and soybean fields. Journal of Environmental Management, 129, 652-664. https://doi.org/10.1016/j.jenvman.2013.05.040

Parkin, T. B., \& Hatfield, J. L. (2010). Influence of nitrapyrin on $\mathrm{N}_{2} \mathrm{O}$ losses from soil receiving fall-applied anhydrous ammonia. Agriculture, Ecosystems \& Environment, 136(1-2), 81-86. https://doi.org/10.1016/j.agee.2009.11.014 
Parkin, T. B., \& Hatfield, J. L. (2014). Enhanced efficiency fertilizers: Effect on nitrous oxide emissions in Iowa. Agronomy Journal, 106(2), 694-702. https://doi.org/10.2134/agronj2013.0219

Parkin, T. B., Kaspar, T. C., Jaynes, D. B., \& Moorman, T. B. (2016). Rye cover crop effects on direct and indirect nitrous oxide emissions Soil Science Society of America Journal, 80(6), 1551-1559. https://doi.org/10.2136/sssaj2016.04.0120

Pelster, D. E., Chantigny, M. H., Rochette, P., Angers, D. A., Rieux, C., \& Vanasse, A. (2012). Nitrous oxide emissions respond differently to mineral and organic nitrogen sources in contrasting soil types. Journal of Environmental Quality, 41(2), 427-435. https://doi.org/ 10.2134/jeq2011.0261

Phillips, R. L., Tanaka, D. L., Archer, D. W., \& Hanson, J. D. (2009). Fertilizer application timing influences greenhouse gas fluxes over a growing season. Journal of Environmental Quality, 38(4), 1569-1579. https://doi.org/10.2134/jeq2008.0483

Recio, J., Alvarez, J. M., Rodriguez-Quijano, M., \& Vallejo, A. (2019). Nitrification inhibitor DMPSA mitigated $\mathrm{N}_{2} \mathrm{O}$ emission and promoted NO sink in rainfed wheat. Environmental Pollution, 245, 199-207. https://doi.org/10.1016/j.envpol.2018.10.135

Sistani, K. R., Jn-Baptiste, M., Lovanh, N., \& Cook, K. L. (2011). Atmospheric emissions of nitrous oxide, methane, and carbon dioxide from different nitrogen fertilizers. Journal of Environmental Quality, 40(6), 1797-1805. https://doi.org/10.2134/jeq2011.0197

Smith, C. M., David, M. B., Mitchell, C. A., Masters, M. D., Anderson-Teixeira, K. J., Bernacchi, C. J., \& DeLucia, E. H. (2013). Reduced nitrogen losses after conversion of row crop agriculture to perennial biofuel crops. Journal of Environmental Quality, 42(1), 219-228. https://doi.org/10.2134/jeq2012.0210

Tenuta, M., Gao, X., Flaten, D. N., \& Amiro, B. D. (2016). Lower nitrous oxide emissions from anhydrous ammonia application prior to soil freezing in late fall than spring pre-plant application. Journal of Environmental Quality, 45(4), 1133-1143. https://doi.org/10.2134/ jeq2015.03.0159

Thornton, F. C., Bock, B. R., \& Tyler, D. D. (1996). Soil emissions of nitric oxide and nitrous oxide from injected andydrous ammonium and urea. Journal of Environmental Quality, 25(6), 1378-1384. https://doi.org/10.2134/jeq1996.00472425002500060030x

Tian, D., Zhang, Y. Y., Mu, Y. J., Zhou, Y. Z., Zhang, C. L., \& Liu, J. F. (2017). The effect of drip irrigation and drip fertigation on $\mathrm{N}_{2} \mathrm{O}$ and NO emissions, water saving and grain yields in a maize field in the North China Plain. Science of the Total Environment, 575, 1034-1040. https://doi.org/10.1016/j.scitotenv.2016.09.166

van Kessel, C., Venterea, R., Six, J., Adviento-Borbe, M. A., Linquist, B., \& van Groenigen, K. J. (2013). Climate, duration, and N placement determine $\mathrm{N}_{2} \mathrm{O}$ emissions in reduced tillage systems: A meta-analysis. Global Change Biology, 19(1), 33-44. https://doi.org/10.1111/ j.1365-2486.2012.02779.x

Venterea, R. T., Dolan, M. S., \& Ochsner, T. E. (2010). Urea decreases nitrous oxide emissions compared with anhydrous ammonia in a Minnesota corn cropping system. Soil Science Society of America Journal, 74(2), 407-418. https://doi.org/10.2136/sssaj2009.0078

Venterea, R. T., Maharjan, B., \& Dolan, M. S. (2011). Fertilizer source and tillage effects on yield-scaled $\mathrm{N}_{2} \mathrm{O}$ emissions in a corn-cropping system. Journal of Environmental Quality, 40(5), 1521-1531. https://doi.org/10.2134/jeq2011.0039

Vinzent, B., Fuss, R., Maidl, F. X., \& Hulsbergen, K. J. (2018). $\mathrm{N}_{2} \mathrm{O}$ emissions and nitrogen dynamics of winter rapeseed fertilized with different N forms and a nitrification inhibitor. Agriculture, Ecosystems \& Environment, 259, 86-97. https://doi.org/10.1016/j. agee.2018.02.028

Wei, X. R., Hao, M. D., Xue, X. H., Shi, P., Horton, R., Wang, A., \& Zang, Y. F. (2010). Nitrous oxide emission from highland winter wheat field after long-term fertilization. Biogeosciences, 7(10), 3301-3310. https://doi.org/10.5194/bg-7-3301-2010

Woodley, A. L., Drury, C. F., Yang, X. M., Reynolds, W. D., Calder, W., \& Oloya, T. O. (2018). Streaming urea ammonium nitrate with or without enhanced efficiency products impacted corn yields, ammonia, and nitrous oxide emissions. Agronomy Journal, 110 (2), 444-454. https://doi.org/10.2134/agronj2017.07.0406

Yuan, M., Greer, K. D., Nafziger, E. D., Villamil, M. B., \& Pittelkow, C. M. (2018). Soil $\mathrm{N}_{2} \mathrm{O}$ emissions as affected by long-term residue removal and no-till practices in continuous corn. Global Change Biology. Bioenergy, 10(12), 972-985. https://doi.org/10.1111/gcbb.12564

Zebarth, B. J., Rochette, P., Burton, D. L., \& Price, M. (2008). Effect of fertilizer nitrogen management on $\mathrm{N}_{2} \mathrm{O}$ emissions in commercial corn fields. Canadian Journal of Soil Science, 88(2), 189-195. https://doi.org/10.4141/CJSS06010 


\title{
QAGUPUBLICATIONS
}

Earth's Future

Supporting Information for

Quantifying On-farm Nitrous Oxide Emission Reductions in Food-Supply Chains

\author{
A. J. Eagle', E. L. McLellan', E. M. Brawner², M. H. Chantigny'³, E. A. Davidson ${ }^{4}$, J. B. Dickey ${ }^{5}$, B. A. \\ Linquist ${ }^{6}$, T. M. Maaz ${ }^{7}$, D. E. Pelster ${ }^{3}$, C. M. Pittelkow ${ }^{6}$, C. van Kessel ${ }^{6}$ †, T. J. Vyn', and K. G. \\ Cassman ${ }^{9} \dagger$ \\ 'Environmental Defense Fund. ${ }^{2}$ Environmental Defense Fund (contractor). ${ }^{3}$ Agriculture and Agri-Food Canada. \\ ${ }^{4}$ University of Maryland Center for Environmental Science. ${ }^{5}$ PlanTierra LLC. ${ }^{6}$ University of California-Davis. \\ ${ }^{7}$ University of Hawaii. ${ }^{8}$ Purdue University. ${ }^{9}$ University of Nebraska-Lincoln. [†Emeritus]
}

\section{Contents of this file}

Text $\mathrm{S} 1$ to $\mathrm{S} 6$

Figure $\mathrm{S} 1$

Tables S1, S5 to S7

\section{Additional Supporting Information (Files uploaded separately)}

Captions for Tables S2 to S4

\section{Introduction}

The article uses results from a meta-analysis of agricultural field-experiment data to illustrate the value of using nitrogen $(\mathrm{N})$ balance as a robust indicator for direct nitrous oxide $\left(\mathrm{N}_{2} \mathrm{O}\right)$ emissions. The data are drawn from documented and measured annual or growing season management, productivity, and environmental outcomes from major field crops that comprise a large portion of the food supply chain. This supporting information contains additional details on methods and results, descriptions of the data included in the analysis, and justification for excluding research studies that have appeared in other syntheses. The dataset is available from the Purdue University Research Repository (https://doi.org/10.4231/DFB0F030)). 


\section{Text S1. Data Sources}

The systematic search for data-containing literature followed procedures as in earlier metaanalyses (Eagle et al. 2017; McLellan et al. 2018). We used the earlier papers retrieved in those prior searches, and then repeated the Web of Science search with the same search terms [fertiliz(er/ation), management, agricultur(e/al), nitrogen, nutrient, nitrous oxide] to find additional studies published since September 2016 and through May 2019. Individual searches were made manageable when necessary (to return a reasonable number of citations, i.e., <1000) by using a larger number of search terms [United States, maize, corn]. With a large number of studies to review, initial triage consisted of excluding for irrelevance based on obvious characteristics within the title (e.g., not cropping systems or agriculture).

Secondary triage excluded studies after reviewing abstracts, removing perennial crops, greenhouse or lab studies, tropical studies, irrigated systems, and those clearly not measuring $\mathrm{N}_{2} \mathrm{O}$ emissions. For all remaining studies, we attempted to locate copies of the papers, and searched within for relevant data. At this stage, unless recently published (with potential to contact authors for data) or referencing companion papers, studies were discarded if yield or $\mathrm{N}$ uptake were not reported or if $\mathrm{N}_{2} \mathrm{O}$ emissions data were combined across years or treatments, or were otherwise outside of scope (e.g., only fluxes reported but not cumulative). To ensure that all potential studies were located, we also located all possible studies noted in other meta-analyses and primary research articles as containing valuable $\mathrm{N}_{2} \mathrm{O}$ data from cropping systems. Data were entered into our database as site-treatment-year observations, standardizing covariate management and weather data as much as possible.

The data were sought as and categorized into five different data subsets (Table S1). Data subset 1 contains the McLellan et al. (2018) N Balance- $\mathrm{N}_{2} \mathrm{O}$ model studies of rainfed (nonirrigated) maize systems on silt loam soils in the North American Corn Belt, using only synthetic $\mathrm{N}$ fertilizer. Silt loam soils represent the largest proportion of maize production in the Corn Belt, hence the focus on this soil texture class for the initial modeling effort. Subsets 2 and 3 augment the previous dataset with additional published field studies from rainfed maize systems in the Corn Belt, separated into silt loam and other soils, respectively, for these two groups. Maize grown for grain is the only crop in these first three groups. Subset 4 comprises studies where maize - for either grain or silage - received manure as a fertilizer $\mathrm{N}$ source, and subset 5 includes other rainfed crops and regions across the globe.

We also excluded irrigated crops in this analysis. Nitrous oxide emissions are highly dependent on soil water content, and thus responsive to irrigation management practices. For example, emissions in drip irrigated systems are much lower than in surface irrigated systems (Bronson et al. 2018; Tian et al. 2017). Therefore, $\mathrm{N}_{2} \mathrm{O}$ emission mitigation in irrigated systems involves co-management of both water and nutrients and increased understanding thereof would benefit from a closer look outside the scope of this study.

Nitrous oxide emissions from agricultural land are characterized by hot spots and hot moments. In order to accurately portray the typical annual cropping system, our dataset was carefully screened to exclude a number of experiments or portions of experiments that clearly stand out as anomalies. Very high emissions have been observed in certain less-common situations, such as recent conversion from long-term grassland (Gagnon et al. 2011), saturated high-clay content soils (Gagnon et al. 2011), and farmed histosols (Duxbury et al. 1982). 
We included studies if they measured $\mathrm{N}_{2} \mathrm{O}$ emissions for a sufficient period of time during the growing season so as to capture the peak emission fluxes (i.e., zero or very low emissions at start and end of sampling period). This also meant that emissions were confirmed or expected to return to baseline (that of the control plots) before sampling ceased. The shortest sampling timeframe that accomplished this requirement was an experiment with 70 days of $\mathrm{N}_{2} \mathrm{O}$ emission measurements (Omonode et al. 2015), for which authors illustrated that they captured the peak $\mathrm{N}_{2} \mathrm{O}$ emissions and that fluxes returned to baseline before ending measurements. Thus the shortest timeframe included was 70 days from beginning to end of the sampling period. All studies we reviewed that had shorter sampling time frames ( 55 days and less) were unlikely to capture peak emissions, began sampling mid-season, or ceased sampling before emissions returned to baseline.

Even with this restriction, it was clear that the shorter sampling timeframes were not capturing the full emission profiles from these fields, as can be seen with the significant impact of sampling timeframe on cumulative emissions. However, while this shows that short timeframes do not provide the best or complete information, lack of resources (finances or labor) may dictate shorter field sampling seasons, and a correction factor such as we determined may help fill the gap.

Details on the source publications, locations of studies, and other experiment information is provided in Table S2 (maize in the North American Corn Belt) and Table S3 (other crops and regions). The model dataset included only experiments with more than one non-zero $\mathrm{N}$ rate and excluded all zero-N treatments, while the expanded dataset (described in Table S5) brought these observations back in for robustness checks. With the selection criteria specific to each data group, both the model dataset and the expanded dataset excluded a number of studies (or portions thereof) that were included in prior meta-analyses or syntheses (Table S4).

Management, soil, weather, yield and $\mathrm{N}$ loss data were compiled from articles, their supplemental materials, companion publications, and directly from study authors. Each observation represents the reported results from a specific site, for a given crop year, with a specific treatment, or site-year-treatment. Data for each site-year-treatment includes $\mathrm{N}_{2} \mathrm{O}$ losses and $\mathrm{N}$ balance information as well as fertilizer management (4Rs), tillage and other management, plus soil and environmental conditions. Where not available from the published data or related sources, soil carbon and weather data were obtained from publicly available databases using research-site location information (Table S6).

All cropping systems included in our dataset produced one main crop in the span of one year. Depending on the location and the field researchers, a year may have different definitions some report results by calendar year, others by hydrologic year (e.g., Oct to Sept in some parts of the Corn Belt). Published data were most often not broken down into smaller timeframes in order to enable post hoc standardization. Further, given the current state of available data (i.e., sparse), trying to force all datasets into a calendar year or other standard definition would likely result in lost observations because of missing data.

\section{Text S2. Setting up the Data}

To facilitate comparison across diverse studies, $\mathrm{N}$ flows (fertilizer, harvested $\mathrm{N}$ etc.), weather, and soil parameters were standardized to SI units, and crop yield converted to standard moisture content before standardizing in SI units as well. $\mathrm{N}$ balance was calculated in the basic 
system as the total fertilizer $\mathrm{N}$ added minus grain $\mathrm{N}$ removed; manure $\mathrm{N}$ additions (total $\mathrm{N}$, including organic) and residue removal were also applicable in given cases. While $\mathrm{N}$ balance estimated from measured $\mathrm{N}$ in the crop provides greatest accuracy, many studies measuring $\mathrm{N}_{2} \mathrm{O}$ emissions did not also measure $\mathrm{N}$ removed. Therefore, following previous research (Tenorio et al. 2019), and with sufficient data within the current dataset to validate the approach (see Text S3), we estimated grain N for maize in the Corn Belt if $\mathrm{N}$ removed was not reported or otherwise available. In such cases, grain $\mathrm{N}$ was calculated using crop yield and standard IPNI N uptake values (IPNI 2014). For all other crops, only studies reporting N uptake and removal were included. This should be additional explanatory text, such as: extended descriptions of results, full details of models, extended lists of acknowledgements etc. It should not be additional discussion, analysis, interpretation or critique. It should not be an additional scientific experiment or paper.

\section{Text S3. Methodological Note: Estimating N uptake with "Book Values"}

In previous research we concluded that book values such as those published by the International Plant Nutrition Institute (IPNI 2014) were sufficient estimates of grain N concentration for the supply-chain context (Tenorio et al. 2019). Other research suggests that this may be limited to certain time periods and hybrids (Mueller and Vyn 2016). In the current dataset we have data for measured grain $\mathrm{N}$ and whole plant $\mathrm{N}$ from a number of studies and can compare these values to ones estimated using the measured crop yield from the same observations. The estimated $\mathrm{N}$ harvested for grain corn was on average $4.4 \%$ greater than measured harvested $\mathrm{N}$ - and estimated $\mathrm{N}$ uptake for silage corn averaged $55 \%$ greater than measured - but note that the sample size was very small $(n=26)$. The close relationship for grain corn indicates that using crop yield and book values for grain $\mathrm{N}$ to calculate $\mathrm{N}$ balance is appropriate - and with a slight overestimated $\mathrm{N}$ removal, $\mathrm{N}$ balances estimated would tend to be conservative, i.e., less likely to point out "false positive" excessive $\mathrm{N}$ balances). However, the large deviation from actual for silage corn means that conclusions based on estimated $\mathrm{N}$ removal are likely to be unreliable. Therefore, we restrict analyses with silage corn (and all other crops) in our dataset to observations that report measured $\mathrm{N}$ removal.

\section{Text S4. Statistical Analysis}

We began by calculating the relationship between $\mathrm{N}_{2} \mathrm{O}$ emissions and $\mathrm{N}$ balance on an areascaled basis. Data for $\mathrm{N}_{2} \mathrm{O}$ were transformed (natural log) and regressed against $\mathrm{N}$ balance within a hierarchical multi-level model using the STATA mixed command, grouped by research site and data subset. As this relationship is expected to be modified by other factors that affect nutrient cycling and crop performance, all such factors with data available were tested for inclusion in the models.

\section{Variable selection}

Nitrous oxide fluxes from soils are affected by management and environmental factors. Therefore, alternate model specifications were compared to assess which of these consistently influenced total cumulative emissions or the relationship between $\mathrm{N}$ balance and $\mathrm{N}_{2} \mathrm{O}$ emissions. Management factors considered and tested in different models include the following: fertilizer $\mathrm{N}$ rate, source [which also includes inhibitors and coatings], timing and placement (the 4Rs); tillage system (conventional, conservation, no-till); crop species; previous-year's crop species; winter cover crop; Environmental factors considered were: long- 
term (30-yr) average and current-calendar-year precipitation, mean annual temperature and mean July temperature; soil texture class; soil percent clay; soil C content. Experimental factors such as length of $\mathrm{N}_{2} \mathrm{O}$ monitoring period and frequency of measurements were also included as available. Knowing the experiment year, we also tested for trends over time and year-byyear impacts otherwise not captured in the weather patterns previously mentioned. Only those factors that consistently explained variability in the relationship were included in the final models.

Some versions of the models suggested that $\mathrm{N}_{2} \mathrm{O}$ emissions were higher in soils with greater clay content, but this did not carry through consistently. Because clay content and soil $\mathrm{C}$ content are positively correlated overall, the inclusion of soil C (which was more clearly a significant factor) may provide some of the same transformation.

While other research and models suggest that tillage systems affect $\mathrm{N}_{2} \mathrm{O}$ emissions (see for e.g., van Kessel et al., 2013), the tillage systems compared in the current dataset did not consistent explain differences. A recent paper from Indiana, published in JEQ (Omonode and Vyn, 2019) tested tillage and $\mathrm{N}$ source impacts on $\mathrm{N}_{2} \mathrm{O}$ emissions in continuous corn and observed only slight reductions in seasonal $\mathrm{N}_{2} \mathrm{O}$ loss with no-till in 2 of 3 years, with an absence of a tillage consequence in the third year. Those authors found an average of just $4 \%$ $\mathrm{N}_{2} \mathrm{O}$ reductions in no-till relative to chisel plow and $8 \% \mathrm{~N}_{2} \mathrm{O}$ reductions in no-till relative to moldboard plow. The disk-chisel plow system is the most popular current form of "conventional" tillage in U.S. corn production.

\section{Testing between groups}

In models with the restricted dataset and those using the expanded one, no evidence emerged to suggest different slopes between data subsets for the relationship between $\mathrm{N}_{2} \mathrm{O}$ and $\mathrm{N}$ balance. Of special importance was determining whether maize demonstrated consistent differences from other crops in $\mathrm{N}_{2} \mathrm{O}$ emissions - specifically the relationship between $\mathrm{N}_{2} \mathrm{O}$ and $\mathrm{N}$ balance. Initial models with only the data subset $\mathrm{E}$ (other crops \& regions) suggested that $\mathrm{N}_{2} \mathrm{O}$ emissions were higher from maize than from other crops, introducing a shift upward of the relationship curve. However, after removing the Mediterranean "other crops \& regions" locations in Spain (which experienced both lower total rainfall and lower emissions than other studies), this trend disappeared. Therefore, at the same level of $\mathrm{N}$ balance, differences in emissions between maize and other crops are most likely an artifact of maize being grown in wetter regions than some other non-irrigated grain crops.

\section{Choosing levels and groups for hierarchical model}

As with exploring the potential impact of different co-variates, we tested whether grouping the data into locations and into datasets improved model fit. Grouping allows for separation of the remaining model variance into that within groups and between groups. Unexplained differences between groups (i.e., between research sites) can include weather, soil, or management factors either unavailable or interacting with one another in ways we do not understand. Wald test results from the Stata mixed command provide evidence that grouping by both location and by data subset explained more of the variability than without these groups. Thus, there are similarities between observations at a given experiment site that are not otherwise captured - and there are similarities between observations within a data subset also not otherwise captured. For the latter, this means, for example, that something about the other crops and regions data links observations in that data subset more tightly together than with observations in other data subsets. 


\section{Text S5. Model Form Comparisons}

While other model forms (i.e., linear, piece-wise regression) were tested, the log-linear (exponential) relationship between $\mathrm{N}_{2} \mathrm{O}$ emissions and $\mathrm{N}$ balance best fit the data and aligned with the theoretical mechanistic understanding (see below).

Piecewise regressions estimated for different combinations of studies did not resolve into relationships that were consistent with theory. The breakpoints (at which slope of the line changed) ranged from negative values to relatively high positive values, and the slope of the second/"upper" portion of the line was at times less than that of the first/"lower" portion. This result is most likely due to the paucity of data with wider distributions of $\mathrm{N}$ balance within a site-year, and especially a result of the small number of observations at $\mathrm{N}$ balances above $\sim 50$ $\mathrm{kg} \mathrm{N} / \mathrm{ha}$. Because of this, and because the one site-year with well-defined and broadly distributed data was best modeled with an exponential relationship, piecewise regressions were not explored further for the combined datasets.

Given the ongoing discussion in the soils and agronomic literature about linear versus exponential relationships between $\mathrm{N}_{2} \mathrm{O}$ emissions and $\mathrm{N}$ balance (or $\mathrm{N}$ rate), we compared these model forms in more detail for the different data subsets and the expanded $(n=805)$ and restricted ( $n=286$ ) combined datasets. Table S7 presents $R^{2}$ values as well as AIC and BIC results. For two models fit on the same data, the model with the smaller value of AIC and BIC is considered to be better (see Stata manual for references and additional information). Therefore, we conclude that exponential models (using the natural $\log$ of $\mathrm{N}_{2} \mathrm{O}$ emissions to perform a linear regression against $\mathrm{N}$ balance) are the most appropriate for these data.

Overall, compared to linear models, the log-linear (exponential) models explained the same amount or more variability in the data across all datasets. Further, $\mathrm{N}$ balance explained about the same amount of variability in the data set as did $\mathrm{N}$ rate.

\section{Text S6. Adjustments to the Mean}

The final model illustrated in Figure 3 includes adjustments for three different factors that consistently explained variability in the data - mean average annual precipitation $(\mathrm{mm})$, soil C concentration ( $\mathrm{g} \mathrm{C} / \mathrm{kg}$ soil), and $\mathrm{N}_{2} \mathrm{O}$ measurement timeframe (days). On average, in the expanded [restricted] model, $\mathrm{N}_{2} \mathrm{O}$ emissions increased by $7 \%$ [5\%] for a $10 \mathrm{~kg} \mathrm{~N} /$ ha increase in $\mathrm{N}$ balance, by $11 \%$ [19\%] for every $100 \mathrm{~mm}$ additional annual precipitation, by $6 \%$ [16\%] for every 30 extra days of sampling time, and by $5 \%$ [3\%] for each $0.1 \%$ increase soil C concentration (e.g., moving from 2.0 to $2.1 \%$ soil C). The individual observations (open circles) in Figure 3 were thus adjusted to show what they would have been if the values for each of these three variables were at the mean for the whole dataset. For example, the emission value for an observation with $100 \mathrm{~mm}$ more annual precipitation than average was adjusted down by $19 \%$. Thus we can see (as best as possible) how these data would appear without the variability caused by precipitation, sampling timeframe and soil carbon concentration.

The significant impact of rainfall and soil $\mathrm{C}$ may provide opportunities for differentiation by region or soil type of a model like this, if resources or the benefits of such groupings would be sufficient to warrant the necessary additional data collection and analysis. However, this falls 
outside the scope of the current supply-chain requirement for a generalized model. The positive impact of modeling timeframe on $\mathrm{N}_{2} \mathrm{O}$ losses suggests that (unless or until research data with longer-term measures are more readily available) adjustments upward could help account for full-year emissions. We only used data from studies likely to capture peak emissions, with baseline or near-zero emissions at the beginning and end of the sampling period. However, even with this restriction, the significant impact of sampling timeframe shows that the shorter sampling timeframes were not capturing the full emission profiles. On the other hand, lack of resources (finances or labor) may dictate shorter field sampling seasons for many research programs, and a correction factor such as we determined may help fill the gap. 


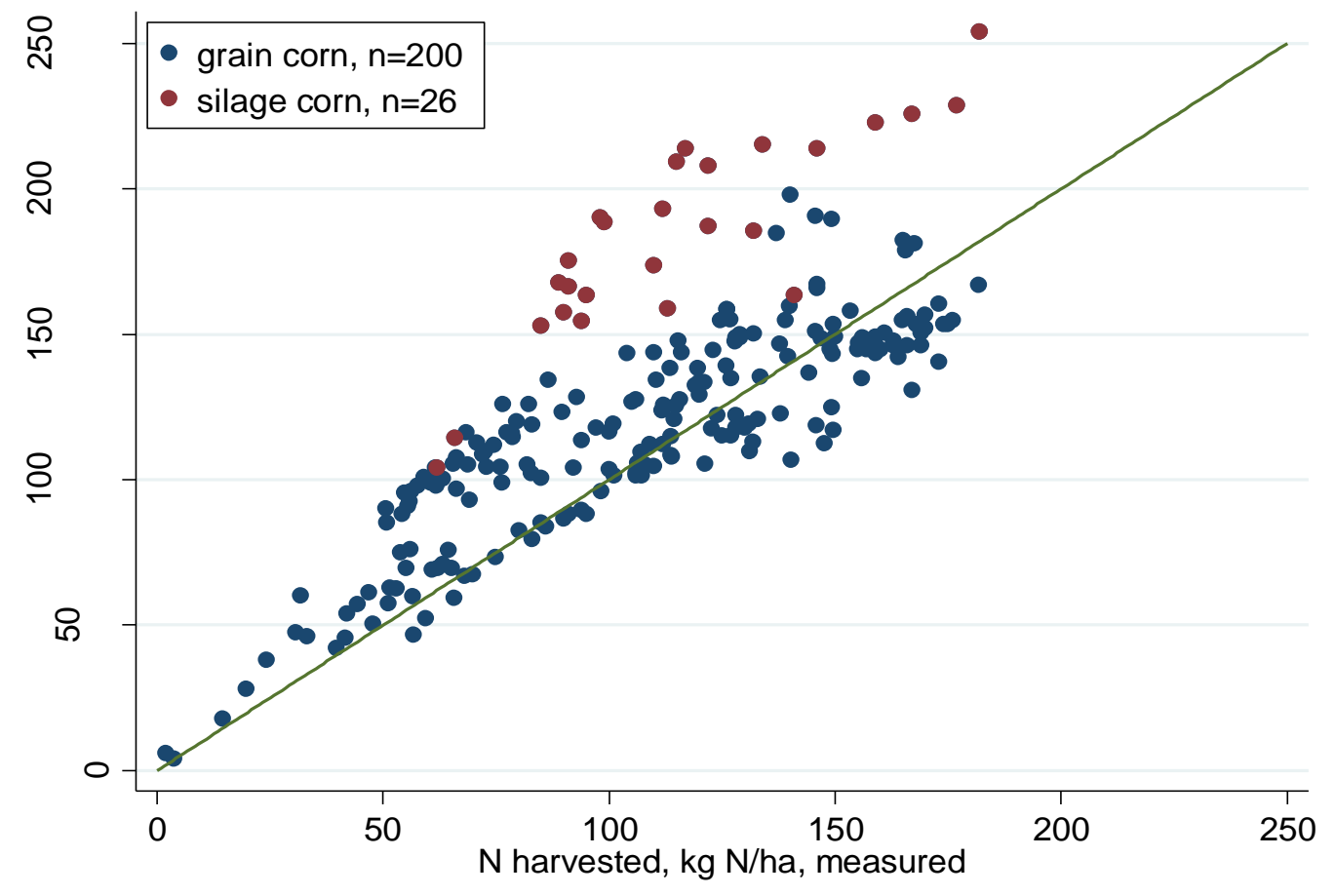

Figure S1. Comparison of measured $\mathrm{N}$ removed (harvested) with estimates derived from crop yield and IPNI book values for grain N content. Data source is current dataset, all observations with measured $\mathrm{N}$ removed, grain corn (maize) and silage corn. 


\begin{tabular}{|c|c|}
\hline Dataset & Selection criteria \\
\hline All data & $\begin{array}{l}\text { - Field studies only (no greenhouse or pot experiments) } \\
\text { - Rain-fed (non-irrigated) } \\
\text { - Peer-reviewed; exception - PhD/MS theses if reporting grain } \mathrm{N} \\
\text { - } \mathrm{N}_{2} \mathrm{O} \text { emissions measured over period of } 70+\text { days and at least once per week } \\
\text { during growing season } \\
\text { - Expected } \mathrm{N}_{2} \mathrm{O} \text { peak emission captured (zero or low emissions at beginning and } \\
\text { end of measurement period) } \\
\text { - } \mathrm{N} \text { applied rate and crop yield data available; yield or full-factorial (i.e., year } \times \\
\text { treatment) data may be author-supplied } \\
\text { - Exclude "novel" treatments with little to no current on-farm representation (e.g., } \\
\text { controlled drainage), but include zero } \mathrm{N} \text { control plots if available } \\
\text { - At least two site } \times \text { treatment } \times \text { year observations per study } \\
\text { - Data NOT averaged across years, } \mathrm{N} \text { rates, or rotations (average across other } \\
\text { treatments OK if study shows these have no } \mathrm{N} \text { cycling effect) }\end{array}$ \\
\hline $\begin{array}{l}\text { Subset 1: Maize in the } \\
\text { Corn Belt } \\
\text { (studies in original N } \\
\text { Balance model, } \\
\text { McLellan et al. 2018) }\end{array}$ & $\begin{array}{l}\text { - Grain maize, north-central U.S. and southeast Canada } \\
\text { - Maize/soy or continuous maize rotations } \\
\text { - Silt loam soils only } \\
\text { - N added as synthetic fertilizer only } \\
\text { - No manure in past two years } \\
\text { - No recent conversions from grassland or alfalfa } \\
\end{array}$ \\
\hline $\begin{array}{l}\text { Subset 2: Maize in the } \\
\text { Corn Belt (data } \\
\text { compiled since } \\
\text { McLellan et al. 2018) }\end{array}$ & $\begin{array}{l}\text { - Same as subset } 1, \text { but recently published studies (through May 2019) or studies } \\
\text { with yield or full-factorial data recently obtained. }\end{array}$ \\
\hline $\begin{array}{l}\text { Subset 3: Maize in the } \\
\text { Corn Belt on other } \\
\text { soils (not silt loam) }\end{array}$ & $\begin{array}{l}\text { - Same as subsets } 1 \text { and } 2 \text {, but soil textures other than silt loam } \\
\text { - Also includes rotations with maize following winter wheat ( } 25 \% \text { of total } \\
\text { observations) }\end{array}$ \\
\hline $\begin{array}{l}\text { Subset 4: Maize with } \\
\text { manure in the Corn } \\
\text { Belt }\end{array}$ & $\begin{array}{l}\text { - Grain or silage maize } \\
\text { - North-central U.S. and southeast Canada } \\
\text { - All soil types } \\
\text { - Study uses manure as N source } \\
\text { - No alfalfa in prior cropping season }\end{array}$ \\
\hline $\begin{array}{l}\text { Subset 5: Other crops } \\
\text { and regions }\end{array}$ & $\begin{array}{l}\text { - Temperate, Mediterranean or semi-arid climates } \\
\text { - Non-legume grain and oilseed (maize, wheat, barley, oats, rye, canola), fiber } \\
\text { (cotton), sugar (sugar beet), or vegetable (potato) crops } \\
\text { - N as synthetic fertilizer only } \\
\text { - Must report crop N removal }\end{array}$ \\
\hline
\end{tabular}

Table S1. Selection criteria for five data subsets relating $\mathrm{N}$ Balance to $\mathrm{N}_{2} \mathrm{O}$ emissions from cropland 
Table S2. Source studies with $\mathrm{N}_{2} \mathrm{O}$ and N Balance data for maize in the North American Corn Belt, sorted by state (U.S.A.) and province (Canada), then by location within each state or province. The number of site-year-treatment observations is listed for both the model dataset (no zero-N treatments, and only experiments with at least two $\mathrm{N}$ rates) and the expanded dataset (including the zero- $\mathrm{N}$ treatments and experiments with no variation in $\mathrm{N}$ rate).

[2020EF001504_tb/S3.pdf]

Table S3. Source studies with $\mathrm{N}_{2} \mathrm{O}$ and N Balance data for other crops and regions (Data subset 5), sorted by state (U.S.A.) and province (Canada) within North America, then by location within each state or province; and sorted by country for studies outside of North America. The number of site-year-treatment observations is listed for both the model dataset (no zero- $\mathrm{N}$ treatments, and only experiments with at least two non-zero $\mathrm{N}$ rates) and the expanded dataset (including the zero- $\mathrm{N}$ treatments and experiments with no variation in $\mathrm{N}$ rate).

[2020EF001504_tbIS4.pdf]

Table S4. Studies used or mentioned in previous agricultural $\mathrm{N}_{2} \mathrm{O}$ emission synthesis and meta-analysis studies, but out of scope or otherwise not useable for this study. These studies are listed as they are cited in previous work(s) - see these articles or their supplemental materials for full citations and further information; listed first by province (Canada), then state (USA), then by name of other countries. 


\begin{tabular}{|c|c|c|c|c|c|}
\hline $\begin{array}{l}\text { Data } \\
\text { subset }^{a}\end{array}$ & Crop(s) & States \& Provinces ${ }^{b, c}$ & Soil texture(s) & N source(s) & $\begin{array}{l}\mathrm{N}_{2} \mathrm{O} \text { monitoring } \\
\text { timeframe, per } \mathrm{yr}\end{array}$ \\
\hline $\begin{array}{l}\text { A } \\
(n=167)\end{array}$ & maize - grain & $\begin{array}{l}\text { MN (55\%), KS (20\%), IN (9\%), KY } \\
(8 \%), \text { IL (4\%), WI (2\%), PA (1\%) }\end{array}$ & silt loam & $\begin{array}{l}\text { urea }(47 \%) \text {, UAN ( } 20 \%) \text {, polymer-coated urea } \\
(\mathrm{PCU} ; 9 \%) \text {, SuperU }(8 \%) \text {, anhydrous ammonia } \\
(\mathrm{AA} ; 7 \%) \text {, other }(9 \%)\end{array}$ & $\begin{array}{l}<6 \mathrm{mo}(54 \%), \geq 6 \mathrm{mo} \\
(46 \%)\end{array}$ \\
\hline $\begin{array}{l}B \\
(n=148)\end{array}$ & maize - grain & $\begin{array}{l}\text { IN (32\%), PA (22\%), MN (18\%), IL } \\
(15 \%), \text { ON (7\%), TN (4\%), ND (1\%) }\end{array}$ & silt loam & $\begin{array}{l}\text { UAN (46\%), urea ( } 22 \%), \text { PCU (9\%), SuperU } \\
(9 \%) \text {, AA }(7 \%) \text {, other }(6 \%)\end{array}$ & $\begin{array}{l}<6 \mathrm{mo}(94 \%), \geq 6 \mathrm{mo} \\
(6 \%)\end{array}$ \\
\hline $\begin{array}{l}C \\
(n=214)\end{array}$ & maize - grain & $\begin{array}{l}\text { ON (40\%), IA ( } 20 \%), \text { MI (17\%), QC } \\
(7 \%), \text { IL (6\%), IN (6\%), SD (4\%), MB } \\
(1 \%)\end{array}$ & $\begin{array}{l}\text { clay loam (39\%), loam (26\%), } \\
\text { silty clay loam ( } 23 \%) \text {, clay (5\%), } \\
\text { other ( } 7 \%)\end{array}$ & $\begin{array}{l}\text { urea }(30 \%), \text { UAN }(27 \%) \text {, ammonium nitrate } \\
\text { (AN; } 20 \%), \text { PCU (12\%), AA (9\%), other ( } 2 \%)\end{array}$ & $\begin{array}{l}<6 \mathrm{mo}(34 \%), \geq 6 \mathrm{mo} \\
(66 \%)\end{array}$ \\
\hline $\begin{array}{l}D \\
(n=98)\end{array}$ & $\begin{array}{l}\text { maize - grain }(73 \%) \text { or } \\
\text { silage }(27 \%)\end{array}$ & $\begin{array}{l}\text { QC (49\%), ON (41\%), IN (4\%), KY } \\
(4 \%), \text { PA (2\%) }\end{array}$ & $\begin{array}{l}\text { loam }(44 \%), \text { clay }(36 \%) \text {, silt loam } \\
(11 \%), \text { silty clay }(5 \%) \text {, silty clay } \\
\text { loam }(4 \%)\end{array}$ & Manure - cattle $(52 \%)$, hog $(43 \%)$, poultry $(4 \%)$ & $\begin{array}{l}<6 \mathrm{mo}(48 \%), \geq 6 \mathrm{mo} \\
(52 \%)\end{array}$ \\
\hline $\begin{array}{l}E \\
(n=178)\end{array}$ & $\begin{array}{l}\text { wheat }(52 \%) \text {, maize } \\
(15 \%) \text {, canola }(16 \%) \text {, } \\
\text { barley }(8 \%) \text {, sugarbeet } \\
(7 \%) \text {, other }(3 \%)\end{array}$ & $\begin{array}{l}\text { Germany ( } 29 \%), \text { MB }(18 \%) \text {, Spain } \\
(16 \%), \text { UK (11\%), Netherlands (6\%), } \\
\text { MN (4\%), QC (9\%), China (4\%), ON } \\
(3 \%) \text {, Australia (1\%) }\end{array}$ & $\begin{array}{l}\text { silt loam }(33 \%) \text {, clay }(19 \%) \text {, } \\
\text { sandy loam }(12 \%) \text {, clay loam } \\
(11 \%) \text {, loam }(10 \%) \text {, sand }(4 \%), \\
\text { silty clay }(3 \%) \text {, other }(9 \%)\end{array}$ & $\begin{array}{l}\text { urea }(37 \%) \text {, UAN }(18 \%) \text {, calcium ammonium } \\
\text { nitrate (CAN; } 10 \%) \text {, ammonium sulfate }(10 \%) \text {, } \\
\text { PCU (4\%), SuperU (3\%), AN (3\%), other/ } \\
\text { unknown (19\%) }\end{array}$ & $\begin{array}{l}<6 \mathrm{mo}(49 \%), \geq 6 \mathrm{mo} \\
(51 \%)\end{array}$ \\
\hline
\end{tabular}

a Data sources: ( ${ }^{*}$ indicates non-zero observations also appear in restricted model):

A: Adviento-Borbe et al. (2010), Arango Argoti (2013), Fernández et al. (2015), Maharjan and Venterea (2014), Mendes Bastos (2015), Osterholz et al. (2014)*, Sistani et al. (2011), Smith et al. (2011)*, Smith et al. (2013), Venterea and Coulter (2015)*, Venterea et al. (2011), Venterea et al. (2016)*

B: Burzaco et al. (2013)*, Congreves et al. (2017)*, Dell et al. (2014), Graham et al. (2018), Maharjan and Venterea (2013), Nangia et al. (2013), Omonode and Vyn (2019), Phillips et al. (2009), Thornton and Valente (1996)*, Thornton et al. (1996), Venterea et al. (2010), Wagner-Riddle et al. (2007)*, Yuan et al. (2018)

C: Almaraz et al. (2009), Chantigny et al. (2013), Drury et al. (2006), Drury et al. (2012), Drury et al. (2014), Drury et al. (2017), Fernández et al. (2015), Graham et al. (2018), Hernandez-Ramirez et al. (2009)*, Hoben et al. (2011)*, Iqbal et al. (2015)*, Lehman and Osborne (2013), Omonode et al. (2015)*, Parkin and Hatfield (2010), Parkin and Hatfield (2014), Parkin et al. (2016), Pelster et al. (2011)*, Roy et al. (2014)*, Tenuta et al. (2016), Woodley et al. (2018)

D: Abalos et al. (2016a)*, Adviento-Borbe et al. (2010), Cambareri et al. (2017a)*, Cambareri et al. (2017b), Chantigny et al. (2010)*, Chantigny et al. (2013), Hernandez-Ramirez et al. (2009)*, Rochette et al. (2008)*, Schwager et al. (2016)*, Sistani et al. (2011)

E: Abalos et al. (2013), Asgedom et al. (2014)*, Barton et al. (2008), Chantigny et al. (2013), Gao et al. (2015), Guardia et al. (2018), Huerfano et al. (2016), Huerfano et al. (2018), Kaiser et al. (1998)*, Pelster et al. (2012), Recio et al. (2019), Rochette et al. (2008), Schwager et al. (2016), Thapa et al. (2015)*, van Groenigen et al. (2004)*, Vinzent et al. (2018), Wagner-Riddle et al. (2007)*, Webb et al. (2004)*, Wei et al. (2010)

${ }^{\mathrm{b}}$ Two-letter abbreviations correspond to postal system identifiers for U.S. states and Canadian provinces, with the exception of UK (United Kingdom).

'Totals may not sum to $100 \%$ due to rounding.

Table S5. Selected characteristics of five expanded data subsets used to test relationship between $\mathrm{N}_{2} \mathrm{O}$ emissions and $\mathrm{N}$ balance 


\begin{tabular}{|l|l|}
\hline Source details & Type of data collected \\
\hline $\begin{array}{l}\text { NOAA National Centers for Environmental Information } \\
\text { https://www.ncdc.noaa.gov/data-access/land-based-station-data/ } \\
\text { land-based-datasets/climate-normals/1981-2010-normals-data }\end{array}$ & $\begin{array}{l}\text { Temperature and } \\
\text { precipitation, 30-year } \\
\text { average for USA }\end{array}$ \\
\hline $\begin{array}{l}\text { Government of Canada, Canadian Climate Normals } \\
\text { https://climate.weather.gc.ca/climate_normals/ }\end{array}$ & $\begin{array}{l}\text { Temperature and } \\
\text { precipitation, 30-year } \\
\text { average for Canada }\end{array}$ \\
\hline $\begin{array}{l}\text { Goberno de Espana, Valores climatológicos normales } \\
\text { http://www.aemet.es/es/serviciosclimaticos/datosclimatologicos/valoresclimatologicos }\end{array}$ & $\begin{array}{l}\text { Temperature and } \\
\text { precipitation, 30-year } \\
\text { average for Spain }\end{array}$ \\
\hline https://en.climate-data.org/ & $\begin{array}{l}\text { Temperature and } \\
\text { precipitation for world } \\
\text { cities }\end{array}$ \\
\hline $\begin{array}{l}\text { USDA NRCS Soil Survey } \\
\text { https://www.nrcs.usda.gov/wps/portal/nrcs/main/soils/survey/ }\end{array}$ & $\begin{array}{l}\text { Soil texture and soil C } \\
\text { content for USA } \\
\text { (weighted avg of most } \\
\text { common soils in AOI) }\end{array}$ \\
\hline
\end{tabular}

Table S6. Publicly available (online) sources of soil and weather data used to fill gaps in the data record 


\begin{tabular}{|c|c|c|c|c|c|c|}
\hline \multirow[t]{2}{*}{ Data subset } & \multicolumn{3}{|c|}{ Linear } & \multicolumn{3}{|c|}{$\begin{array}{l}\text { Exponential (Log- } \\
\text { linear) }\end{array}$} \\
\hline & $\mathrm{R}^{2}$ & $\mathrm{AIC}$ & $\mathrm{BIC}$ & $\mathrm{R}^{2}$ & AIC & $\mathrm{BIC}$ \\
\hline $\begin{array}{l}\text { Expanded dataset }(\mathrm{n}=805) \\
\quad(\mathrm{MAP}, \mathrm{SC}, \mathrm{TF})\end{array}$ & 0.41 & 3362 & 3399 & 0.55 & 1642 & 1680 \\
\hline $\begin{array}{l}\text { All restricted data }(n=286) \\
\quad(M A P, S C, T F)\end{array}$ & 0.64 & 1076 & 1106 & 0.64 & 471 & 500 \\
\hline A: CBM silt loam, "old" data $(n=167)$ & 0.42 & 659 & 672 & 0.63 & 300 & 312 \\
\hline $\begin{array}{l}\text { A: CBM silt loam, "old" data }(n=69) \\
(M A P, S C)\end{array}$ & 0.72 & 241 & 254 & 0.78 & 100 & 113 \\
\hline $\begin{array}{l}\text { B: CBM silt loam, "new" data }(n=148) \\
\quad(M A P, S C)\end{array}$ & 0.57 & 611 & 629 & 0.71 & 317 & 335 \\
\hline $\begin{array}{l}\text { B: CBC silt loam, "new" data }(n=24) \\
\quad(M A P, S C)\end{array}$ & 0.89 & 72 & 79 & 0.78 & 34 & 41 \\
\hline $\begin{array}{l}\text { C: CBM other soils }(n=214) \\
\quad(S C)\end{array}$ & 0.38 & 963 & 980 & 0.54 & 460 & 477 \\
\hline $\begin{array}{l}\text { C: CBM other soils }(n=64) \\
\text { (TF) }\end{array}$ & 0.47 & 172 & 183 & 0.26 & 141 & 152 \\
\hline $\begin{array}{l}\text { D: CBM, with manure }(\mathrm{n}=98) \\
\quad(\mathrm{MAP}, \mathrm{SC}, \mathrm{TF})\end{array}$ & 0.61 & 456 & 475 & 0.62 & 178 & 196 \\
\hline $\begin{array}{l}\text { D: CBM, with manure }(n=64) \\
\text { (SC) }\end{array}$ & 0.69 & 295 & 306 & 0.63 & 103 & 114 \\
\hline $\begin{array}{l}\text { E: Other crops \& regions }(n=178) \\
\quad(S C, T F)\end{array}$ & 0.36 & 552 & 571 & 0.41 & 367 & 386 \\
\hline $\begin{array}{l}\text { E: Other crops \& regions }(n=65) \\
(S C, T F)\end{array}$ & 0.79 & 134 & 147 & 0.70 & 75 & 88 \\
\hline
\end{tabular}

Table S7. Model form comparisons for linear and exponential relationships between $\mathrm{N}_{2} \mathrm{O}$ emissions and $\mathrm{N}$ balance, different data subsets. All are multi-level hierarchical models, and include co-variates of mean annual precipitation (MAP), soil C concentration (SC), and $\mathrm{N}_{2} \mathrm{O}$ measurement timeframe (TF), where these are significant at $p<0.05$ in at least one of the model forms - abbreviations are noted when these variables are included in the model. 
Table S2. Source studies with $\mathrm{N}_{2} \mathrm{O}$ and $\mathrm{N}$ Balance data for maize in the North American Corn Belt, sorted by state (U.S.A.) and province (Canada), then by location within each state or province. The number of site-year-treatment observations is listed for both the model dataset (no zero- $N$ treatments, and only experiments with at least two $N$ rates) and the expanded dataset (including the zero- $N$ treatments and experiments with no variation in $\mathrm{N}$ rate).

\begin{tabular}{|c|c|c|c|c|c|c|c|c|c|}
\hline & Citation & Location & Year(s) & $\begin{array}{c}\text { Data } \\
\text { subset }\end{array}$ & $\begin{array}{c}\text { Model } \\
\text { dataset (\# } \\
\text { of obs.) } \\
\end{array}$ & $\begin{array}{c}\text { Expanded } \\
\text { dataset (\# } \\
\text { of obs.) }\end{array}$ & Soil texture & Tillage $^{a}$ & $\begin{array}{c}\text { Crop } \\
\text { rotation(s) }\end{array}$ \\
\hline \multicolumn{10}{|c|}{ lowa } \\
\hline & lqbal et al. 2015 & ISU-AgricEngAgron & 2011-13 & subset 3 & 12 & 18 & Loam & NT & C-S \\
\hline & Parkin et al. 2016 & ISU-BooneCo. & 2004-13 & subset 3 & 0 & 10 & Silty clay loam & NT & C-S \\
\hline$\dagger$ & Parkin \& Hatfield 2010 & ISU-BooneCo. & 2006-07 & subset 3 & 0 & 4 & Silty clay loam & CsT & C-S \\
\hline$\ddagger$ & Parkin \& Hatfield 2014 & ISU-BooneCo. & $2009-10$ & subset 3 & 0 & 10 & Silty clay loam & CsT & $\mathrm{C}-\mathrm{C}$ \\
\hline \multicolumn{10}{|c|}{ Illinois } \\
\hline & Fernández et al. 2015-1 ${ }^{c}$ & CSREC-Urbana & 2010 & subset 1 & 0 & 4 & Silt loam & $\mathrm{CP}$ & $\mathrm{C}-\mathrm{C}$ \\
\hline & Fernández et al. 2015-2 & CSREC-Urbana & 2009, 2011 & subset 3 & 0 & 8 & $\begin{array}{l}\text { Silt loam, silty } \\
\text { clay loam }\end{array}$ & $\mathrm{CP}$ & $\mathrm{C}-\mathrm{C}$ \\
\hline * & Graham et al. $2018-1^{d}$ & CSREC-Urbana & $2015-17$ & subset 2 & 0 & 10 & Silt loam & $D$ & C-S \\
\hline * & Graham et al. 2018-2 & CSREC-Urbana & 2015-17 & subset 3 & 0 & 5 & Silty clay loam & $\mathrm{D}$ & C-S \\
\hline$*+$ & Yuan et al. $2018^{\mathrm{e}}$ & CSREC-Urbana & $2015-17$ & subset 2 & 0 & 12 & Silt loam & $\mathrm{CP} ; \mathrm{NT}$ & $\mathrm{C}-\mathrm{C}$ \\
\hline * & Smith et al. 2013 & UIUC Energy Farm & 2009, 2011 & subset 1 & 0 & 2 & Silt loam & Conv & C-C-S \\
\hline \multicolumn{10}{|c|}{ Indiana } \\
\hline${ }^{*}+$ & Burzaco et al. 2013 & Purdue ACRE & 2010-11 & subset 2 & 16 & 24 & Silt loam & Conv & C-S \\
\hline$*$ & Omonode et al. 2015 & Purdue ACRE & 2011-12 & subset 3 & 8 & 8 & Silty clay loam & Conv; NT & C-S \\
\hline${ }^{*}+$ & Omonode and Vyn 2019 & Purdue ACRE & 2015-16 & subset 2 & 0 & 24 & Silt loam & $\begin{array}{c}\mathrm{CP} ; \mathrm{MP} ; \mathrm{NT} ; \\
\mathrm{ST}\end{array}$ & $\mathrm{C}-\mathrm{C}$ \\
\hline$\dagger$ & Smith et al. 2011 & Throckmorton-Purdue & 2005-07 & subset 1 & 15 & 15 & Silt loam & CsT; CP; NT & $\begin{array}{l}\text { C-S, C-S- } \\
\text { Rg[a] }\end{array}$ \\
\hline${ }^{*}+\ddagger$ & $\begin{array}{l}\text { Hernandez-Ramirez et al. } \\
2009-1^{f}\end{array}$ & WQFS & 2005-06 & subset 3 & 4 & 4 & Silty clay loam & $\mathrm{CP}$ & C-C, C-S \\
\hline *十‡ & $\begin{array}{l}\text { Hernandez-Ramirez et al. } \\
2009-2\end{array}$ & WQFS & 2005-06 & subset 4 & 0 & 4 & Silty clay loam & $\mathrm{CP}$ & C-C, C-S \\
\hline \multicolumn{10}{|c|}{ Kansas } \\
\hline * & Mendes Bastos 2015 & KSU AgronNorthFarm & 2013 & subset 1 & 0 & 14 & Silt loam & NT & $\mathrm{C}-\mathrm{C}$ \\
\hline * & Arango-Argoti 2013 & KSU AgronNorthFarm & 2009-11 & subset 1 & 0 & 20 & Silt loam & $\mathrm{CP} / \mathrm{D} ; \mathrm{NT}$ & $\mathrm{C}-\mathrm{C}$ \\
\hline \multicolumn{10}{|c|}{ Kentucky } \\
\hline & Sistani et al. 2011-1 & Bowling Green & 2009-10 & subset 1 & 0 & 14 & Silt loam & NT & $\mathrm{C}-\mathrm{C}$ \\
\hline & Sistani et al. 2011-2 & Bowling Green & 2009-10 & subset 4 & 0 & 4 & Silt loam & NT & $\mathrm{C}-\mathrm{C}$ \\
\hline \multicolumn{10}{|c|}{ Manitoba } \\
\hline & Tenuta et al. 2016 & TGAS-Man/Glenlea & 2012 & subset 3 & 0 & 2 & Clay & Conv & $\mathrm{C}-\mathrm{W}$ \\
\hline
\end{tabular}




\begin{tabular}{|c|c|c|c|c|c|c|c|c|c|}
\hline & Citation & Location & Year(s) & $\begin{array}{c}\text { Data } \\
\text { subset }\end{array}$ & $\begin{array}{c}\text { Model } \\
\text { dataset (\# } \\
\text { of obs.) }\end{array}$ & $\begin{array}{c}\text { Expanded } \\
\text { dataset (\# } \\
\text { of obs.) } \\
\end{array}$ & Soil texture & Tillage $^{a}$ & $\begin{array}{c}\text { Crop } \\
\text { rotation(s) }\end{array}$ \\
\hline \multicolumn{10}{|c|}{ Michigan } \\
\hline$\dagger$ & Hoben et al. 2011 & $\begin{array}{l}\text { KBS, Fairgrove, } \\
\text { Mason, Reese }\end{array}$ & $2007-08$ & subset 3 & 30 & 36 & Loam, sand & $\mathrm{CP}$ & C-S \\
\hline \multicolumn{10}{|c|}{ Minnesota } \\
\hline$\dagger$ & Venterea et al. 2010 & UM-OREP & 2005-07 & subset 2 & 0 & 12 & Silt loam & $\mathrm{CP}$ & $\mathrm{C}-\mathrm{C}, \mathrm{C}-\mathrm{S}$ \\
\hline${ }^{*}+$ & Venterea et al. 2011 & UM-OREP & 2008-10 & subset 1 & 0 & 24 & Silt loam & MP; NT & C-S \\
\hline$\dagger$ & Venterea \& Coulter 2015-1 & UMRS-Rosemount & 2012 & subset 1 & 20 & 22 & Silt loam & CsT & C-C, C-S \\
\hline$\dagger$ & Venterea \& Coulter 2015-2 & UMRS-Rosemount & 2013 & subset 1 & 20 & 22 & Silt loam & CsT & C-C, C-S \\
\hline$\dagger$ & Maharjan \& Venterea 2014 & UMRS-Rosemount & 2010-11 & subset 1 & 0 & 12 & Silt loam & $\mathrm{D} ; \mathrm{NT}$ & C-S \\
\hline \multirow[t]{2}{*}{$\dagger$} & Maharjan \& Venterea 2013 & UMRS-St. Paul & 2011-12 & subset 2 & 0 & 15 & Silt loam & Unk & $\mathrm{C}-\mathrm{C}$ \\
\hline & Venterea et al. 2016 & UMRS-St. Paul & 2014-15 & subset 1 & 10 & 12 & Silt loam & rotoT & $\mathrm{C}-\mathrm{C}$ \\
\hline \multicolumn{10}{|c|}{ North Dakota } \\
\hline & Phillips et al. 2009 & USDA-ARS-NGPRL & 2008 & subset 2 & 0 & 2 & Clay loam & NT & S-W-SF-C \\
\hline \multicolumn{10}{|c|}{ Ontario } \\
\hline & Schwager et al. 2016 & Alfred & 2011-12 & subset 4 & 8 & 10 & Clay & Conv & sic \\
\hline \multirow[t]{4}{*}{ *†‡ } & Wagner-Riddle et al. 2007 & Elora Rsrch Stn & 2000-03 & subset 2 & 4 & 4 & Silt loam & MP; NT & C-S-wW \\
\hline & Congreves et al. 2017 & Elora Rsrch Stn & 2005 & subset 2 & 2 & 2 & Silt loam & Conv; NT & C-S-wW \\
\hline & Roy et al. 2014 & Elora Rsrch Stn & 2011-12 & subset 3 & 6 & 6 & Loam & Conv & $\mathrm{C}-\mathrm{C}$ \\
\hline & Abalos et al. 2016 & Elora Rsrch Stn & 2012-14 & subset 4 & 5 & 5 & Silt loam & Conv & $\mathrm{C}-\mathrm{C}$ \\
\hline${ }^{*} \dagger$ & Cambareri et al. 2017a & Elora Rsrch Stn & 2012-14 & subset 4 & 18 & 21 & Loam & Cultiv & C-S, C-B \\
\hline \multirow[t]{2}{*}{$* \dagger$} & Cambareri et al. 2017b & Elora Rsrch Stn & 2013-14 & subset 4 & 0 & 6 & Loam & Cultiv & C-S, C-B \\
\hline & Nangia et al. 2013 & $\mathrm{n} / \mathrm{r}$ & 2006-09 & subset 2 & 0 & 5 & Silt loam & Conv & C-C-S \\
\hline \multirow[t]{2}{*}{$\dagger$} & Drury et al. 2006 & Whelan Exp Farm & $2000-02$ & subset 3 & 0 & 18 & Clay loam & NT; CsT; MP & C-S-wW \\
\hline & Drury et al. 2012 & Whelan Exp Farm & 2004-06 & subset 3 & 0 & 36 & Clay loam & NT; CsT; MP & C-S-wW \\
\hline$*$ & Drury et al. 2017 & Whelan Exp Farm & 2013-14 & subset 3 & 0 & 14 & Clay loam & Unk & $\mathrm{C}-\mathrm{C}$ \\
\hline *§ & Woodley et al. 2018 & Whelan Exp Farm & 2013-14 & subset 3 & 0 & 6 & Clay loam & Unk & $\mathrm{C}-\mathrm{C}$ \\
\hline$*$ & Drury et al. 2014 & Whelan Exp Farm('59) & 2007-09 & subset 3 & 0 & 6 & Clay & MP & $\mathrm{C}-\mathrm{C}$ \\
\hline \multicolumn{10}{|c|}{ Pennsylvania } \\
\hline & Adviento-Borbe et al. 2010-1 & R.E. Larson ARC & 2006-07 & subset 1 & 0 & 2 & Silt loam & Conv & $\mathrm{C}-\mathrm{C}$ \\
\hline & Adviento-Borbe et al. 2010-2 & R.E. Larson ARC & 2006-07 & subset 4 & 4 & 4 & Silt loam & Conv & $\mathrm{C}-\mathrm{C}$ \\
\hline & Dell et al. 2014 & R.E. Larson ARC & 2009-12 & subset 2 & 0 & 32 & Silt loam & NT & $\mathrm{C}-\mathrm{C}$ \\
\hline
\end{tabular}




\begin{tabular}{|c|c|c|c|c|c|c|c|c|c|}
\hline & Citation & Location & Year(s) & $\begin{array}{c}\text { Data } \\
\text { subset }\end{array}$ & $\begin{array}{c}\text { Model } \\
\text { dataset (\# } \\
\text { of obs.) }\end{array}$ & $\begin{array}{c}\text { Expanded } \\
\text { dataset (\# } \\
\text { of obs.) }\end{array}$ & Soil texture & Tillage $^{a}$ & $\begin{array}{c}\text { Crop } \\
\text { rotation(s) }\end{array}$ \\
\hline \multicolumn{10}{|c|}{ Quebec } \\
\hline${ }^{*} \ddagger$ & Chantigny et al. 2010-1 & AAFC-Chapais & 2004-06 & subset 3 & 0 & 6 & Clay, loam & $\mathrm{MP}$ & $\mathrm{C}-\mathrm{C}$ \\
\hline${ }^{*} \ddagger$ & Chantigny et al. 2010-2 & AAFC-Chapais & 2004-06 & subset 4 & 30 & 36 & Clay, loam & $\mathrm{MP}$ & $\mathrm{C}-\mathrm{C}$ \\
\hline${ }^{*}$ & Rochette et al. 2008b & AAFC-Harlaka & 2002-03 & subset 4 & 8 & 8 & Clay, loam & rotoT & siC \\
\hline$\ddagger$ & Chantigny et al. 2013 & AAFC-Harlaka & $2006-07$ & subset 4 & 0 & 12 & Clay, silty clay & $\mathrm{MP}$ & sic \\
\hline \multirow[t]{2}{*}{ * } & Pelster et al. 2011 & AAFC-L'Acadie & 2004 & subset 3 & 4 & 6 & Clay loam & MP; NT & C-S \\
\hline & Almaraz et al. 2009 & Lods ARC - McGill & 2003 & subset 3 & 0 & 4 & Clay loam & MP; NT & $\mathrm{C}-\mathrm{C}$ \\
\hline \multicolumn{10}{|c|}{ South Dakota } \\
\hline & Lehman \& Osborne 2013 & ESD WSRF & 2008-10 & subset 3 & 0 & 8 & Sandy clay loam & NT & $\begin{array}{c}\text { C-S, C-fP- } \\
\text { wW-S }\end{array}$ \\
\hline \multicolumn{10}{|c|}{ Tennessee } \\
\hline & Thornton \& Valente 1996 & WTES & 1993 & subset 2 & 2 & 3 & Silt loam & NT & $\mathrm{C}-\mathrm{C}$ \\
\hline & Thornton et al. 1996 & WTES & 1994 & subset 2 & 0 & 3 & Silt loam & NT & $\mathrm{C}-\mathrm{C}$ \\
\hline \multicolumn{10}{|c|}{ Wisconsin } \\
\hline & Osterholz et al. 2014 & Arlington Rsrch Stn & 2010-11 & subset 1 & 4 & 4 & Silt loam & Conv; CsT & $\mathrm{C}-\mathrm{C}$ \\
\hline
\end{tabular}

a Tillage abbreviations: Conv (conventional tillage, unspecified), CP (chisel plow), CsT (Conservation tillage, unspecified), Cultiv (Cultivator), D (disk), MP (moldboard plow/mouldboard plough), NT (no-till), rotoT (Rototiller or rotary plow), ST (strip till), Unk (unknown or not specified)

${ }^{b}$ Crop abbreviations: B (barley), C (corn [maize]), siC (silage corn), fP (field pea), Rg (ryegrass; [a] annual, [p] perennial), S (soybean), SF (sunflower), W (wheat), wW (winter wheat)

' Where data from a single publication fit within more than one of the data subsets (e.g., some observations on silt loam soil, others on silty clay loam soil), the publication is listed twice in this table, followed by a "1" or " 2 " to indicate the different group of data.

${ }^{\mathrm{d}}$ Citations preceded by $\mathrm{a}{ }^{*}$ indicate that data for grain $\mathrm{N}$ or silage $\mathrm{N}$ removed were available for all or a portion of observations within these studies.

e Citations preceded by a + indicate that some data not available from the published research were obtained directly from study author(s).

${ }^{f}$ Citations preceded by a $¥$ indicate that data (most often yield or $\mathrm{N}$ uptake) were obtained from companion publication by all or some of the same authors.

${ }^{g}$ Citations preceded by $\mathrm{a}^{\S}$ indicate additional observations are available, but they are also reported in publications listed earlier in this table. For example, Cambareri et al. 2017b report some observations also reported by Cambareri et al. 2017a. These observations are only included once in our dataset. 
Table S2. Source studies with $\mathrm{N}_{2} \mathrm{O}$ and $\mathrm{N}$ Balance data for maize in the North American Corn Belt, sorted by state (U.S.A.) and province (Canada), then by location within each state or province. The number of site-year-treatment observations is listed for both the model dataset (no zero- $N$ treatments, and only experiments with at least two $N$ rates) and the expanded dataset (including the zero- $N$ treatments and experiments with no variation in $\mathrm{N}$ rate).

\begin{tabular}{|c|c|c|c|c|c|c|c|c|c|}
\hline & Citation & Location & Year(s) & $\begin{array}{c}\text { Data } \\
\text { subset }\end{array}$ & $\begin{array}{c}\text { Model } \\
\text { dataset (\# } \\
\text { of obs.) } \\
\end{array}$ & $\begin{array}{c}\text { Expanded } \\
\text { dataset (\# } \\
\text { of obs.) }\end{array}$ & Soil texture & Tillage $^{a}$ & $\begin{array}{c}\text { Crop } \\
\text { rotation }(s)^{b}\end{array}$ \\
\hline \multicolumn{10}{|c|}{ lowa } \\
\hline & lqbal et al. 2015 & ISU-AgricEngAgron & 2011-13 & subset 3 & 12 & 18 & Loam & NT & C-S \\
\hline & Parkin et al. 2016 & ISU-BooneCo. & 2004-13 & subset 3 & 0 & 10 & Silty clay loam & NT & C-S \\
\hline$\dagger$ & Parkin \& Hatfield $2010^{c}$ & ISU-BooneCo. & $2006-07$ & subset 3 & 0 & 4 & Silty clay loam & CsT & C-S \\
\hline$\ddagger^{\wedge}$ & Parkin \& Hatfield 2014 & ISU-BooneCo. & $2009-10$ & subset 3 & 0 & 10 & Silty clay loam & CsT & $\mathrm{C}-\mathrm{C}$ \\
\hline \multicolumn{10}{|c|}{ Illinois } \\
\hline & Fernández et al. 2015-1 ${ }^{f}$ & CSREC-Urbana & 2010 & subset 1 & 0 & 4 & Silt loam & $\mathrm{CP}$ & $\mathrm{C}-\mathrm{C}$ \\
\hline & Fernández et al. 2015-2 & CSREC-Urbana & 2009, 2011 & subset 3 & 0 & 8 & $\begin{array}{l}\text { Silt loam, silty } \\
\text { clay loam }\end{array}$ & $\mathrm{CP}$ & $\mathrm{C}-\mathrm{C}$ \\
\hline * & Graham et al. $2018-1^{\mathrm{g}}$ & CSREC-Urbana & 2015-17 & subset 2 & 0 & 10 & Silt loam & $\mathrm{D}$ & C-S \\
\hline$*$ & Graham et al. 2018-2 & CSREC-Urbana & $2015-17$ & subset 3 & 0 & 5 & Silty clay loam & $\mathrm{D}$ & C-S \\
\hline$*+$ & Yuan et al. $2018^{\mathrm{e}}$ & CSREC-Urbana & $2015-17$ & subset 2 & 0 & 12 & Silt loam & $\mathrm{CP} ; \mathrm{NT}$ & $\mathrm{C}-\mathrm{C}$ \\
\hline$*$ & Smith et al. 2013 & UIUC Energy Farm & 2009,2011 & subset 1 & 0 & 2 & Silt loam & Conv & C-C-S \\
\hline \multicolumn{10}{|c|}{ Indiana } \\
\hline${ }^{*}+$ & Burzaco et al. 2013 & Purdue ACRE & 2010-11 & subset 2 & 16 & 24 & Silt loam & Conv & C-S \\
\hline$*$ & Omonode et al. 2015 & Purdue ACRE & 2011-12 & subset 3 & 8 & 8 & Silty clay loam & Conv; NT & C-S \\
\hline${ }^{*}+$ & Omonode and Vyn 2019 & Purdue ACRE & 2015-16 & subset 2 & 0 & 24 & Silt loam & $\begin{array}{c}\mathrm{CP} ; \mathrm{MP} ; \mathrm{NT} ; \\
\mathrm{ST}\end{array}$ & $\mathrm{C}-\mathrm{C}$ \\
\hline$\dagger$ & Smith et al. 2011 & Throckmorton-Purdue & 2005-07 & subset 1 & 15 & 15 & Silt loam & CsT; CP; NT & $\begin{array}{l}\text { C-S, C-S- } \\
\text { Rg[a] }\end{array}$ \\
\hline${ }^{*}+\ddagger$ & $\begin{array}{l}\text { Hernandez-Ramirez et al. } \\
\text { 2009-1 }\end{array}$ & WQFS & 2005-06 & subset 3 & 4 & 4 & Silty clay loam & $\mathrm{CP}$ & C-C, C-S \\
\hline${ }^{*} \dagger \ddagger$ & $\begin{array}{l}\text { Hernandez-Ramirez et al. } \\
2009-2\end{array}$ & WQFS & 2005-06 & subset 4 & 0 & 4 & Silty clay loam & $\mathrm{CP}$ & C-C, C-S \\
\hline \multicolumn{10}{|c|}{ Kansas } \\
\hline$*$ & Mendes Bastos 2015 & KSU AgronNorthFarm & 2013 & subset 1 & 0 & 14 & Silt loam & NT & $\mathrm{C}-\mathrm{C}$ \\
\hline$*$ & Arango-Argoti 2013 & KSU AgronNorthFarm & 2009-11 & subset 1 & 0 & 20 & Silt loam & $\mathrm{CP} / \mathrm{D} ; \mathrm{NT}$ & $\mathrm{C}-\mathrm{C}$ \\
\hline \multicolumn{10}{|c|}{ Kentucky } \\
\hline & Sistani et al. 2011-1 & Bowling Green & 2009-10 & subset 1 & 0 & 14 & Silt loam & NT & $\mathrm{C}-\mathrm{C}$ \\
\hline & Sistani et al. 2011-2 & Bowling Green & 2009-10 & subset 4 & 0 & 4 & Silt loam & NT & $\mathrm{C}-\mathrm{C}$ \\
\hline \multicolumn{10}{|c|}{ Manitoba } \\
\hline & Tenuta et al. 2016 & TGAS-Man/Glenlea & 2012 & subset 3 & 0 & 2 & Clay & Conv & $C-W$ \\
\hline
\end{tabular}




\begin{tabular}{|c|c|c|c|c|c|c|c|c|c|}
\hline & Citation & Location & Year(s) & $\begin{array}{c}\text { Data } \\
\text { subset }\end{array}$ & $\begin{array}{c}\text { Model } \\
\text { dataset (\# } \\
\text { of obs.) }\end{array}$ & $\begin{array}{c}\text { Expanded } \\
\text { dataset (\# } \\
\text { of obs.) }\end{array}$ & Soil texture & Tillage $^{a}$ & $\begin{array}{c}\text { Crop } \\
\text { rotation(s) }\end{array}$ \\
\hline \multicolumn{10}{|c|}{ Michigan } \\
\hline$\dagger^{\wedge}$ & Hoben et al. 2011 & $\begin{array}{l}\text { KBS, Fairgrove, } \\
\text { Mason, Reese }\end{array}$ & $2007-08$ & subset 3 & 30 & 36 & Loam, sand & $\mathrm{CP}$ & C-S \\
\hline \multicolumn{10}{|c|}{ Minnesota } \\
\hline$\dagger$ & Venterea et al. 2010 & UM-OREP & 2005-07 & subset 2 & 0 & 12 & Silt loam & $\mathrm{CP}$ & C-C, C-S \\
\hline${ }^{*}+$ & Venterea et al. 2011 & UM-OREP & 2008-10 & subset 1 & 0 & 24 & Silt loam & MP; NT & C-S \\
\hline$\dagger$ & Venterea \& Coulter 2015-1 & UMRS-Rosemount & 2012 & subset 1 & 20 & 22 & Silt loam & CsT & C-C, C-S \\
\hline$\dagger$ & Venterea \& Coulter 2015-2 & UMRS-Rosemount & 2013 & subset 1 & 20 & 22 & Silt loam & CsT & C-C, C-S \\
\hline$\dagger$ & Maharjan \& Venterea 2014 & UMRS-Rosemount & 2010-11 & subset 1 & 0 & 12 & Silt loam & $\mathrm{D} ; \mathrm{NT}$ & C-S \\
\hline \multirow[t]{2}{*}{$\dagger$} & Maharjan \& Venterea 2013 & UMRS-St. Paul & 2011-12 & subset 2 & 0 & 15 & Silt loam & Unk & $\mathrm{C}-\mathrm{C}$ \\
\hline & Venterea et al. 2016 & UMRS-St. Paul & 2014-15 & subset 1 & 10 & 12 & Silt loam & rotoT & $\mathrm{C}-\mathrm{C}$ \\
\hline \multicolumn{10}{|c|}{ North Dakota } \\
\hline & Phillips et al. 2009 & USDA-ARS-NGPRL & 2008 & subset 2 & 0 & 2 & Clay loam & NT & S-W-SF-C \\
\hline \multicolumn{10}{|c|}{ Ontario } \\
\hline & Schwager et al. 2016 & Alfred & 2011-12 & subset 4 & 8 & 10 & Clay & Conv & sic \\
\hline \multirow[t]{4}{*}{ *†‡ } & Wagner-Riddle et al. 2007 & Elora Rsrch Stn & 2000-03 & subset 2 & 4 & 4 & Silt loam & MP; NT & C-S-wW \\
\hline & Congreves et al. 2017 & Elora Rsrch Stn & 2005 & subset 2 & 2 & 2 & Silt loam & Conv; NT & C-S-wW \\
\hline & Roy et al. 2014 & Elora Rsrch Stn & 2011-12 & subset 3 & 6 & 6 & Loam & Conv & $\mathrm{C}-\mathrm{C}$ \\
\hline & Abalos et al. 2016 & Elora Rsrch Stn & 2012-14 & subset 4 & 5 & 5 & Silt loam & Conv & $\mathrm{C}-\mathrm{C}$ \\
\hline${ }^{*} \dagger$ & Cambareri et al. 2017a & Elora Rsrch Stn & 2012-14 & subset 4 & 18 & 21 & Loam & Cultiv & C-S, C-B \\
\hline${ }^{*}+\S$ & Cambareri et al. 2017b $\mathrm{b}^{\mathrm{h}}$ & Elora Rsrch Stn & 2013-14 & subset 4 & 0 & 6 & Loam & Cultiv & C-S, C-B \\
\hline$\wedge$ & Nangia et al. 2013 & $\mathrm{n} / \mathrm{r}$ & 2006-09 & subset 2 & 0 & 5 & Silt loam & Conv & C-C-S \\
\hline \multirow[t]{2}{*}{$\dagger$} & Drury et al. 2006 & Whelan Exp Farm & $2000-02$ & subset 3 & 0 & 18 & Clay loam & NT; CsT; MP & C-S-wW \\
\hline & Drury et al. 2012 & Whelan Exp Farm & 2004-06 & subset 3 & 0 & 36 & Clay loam & NT; CsT; MP & C-S-wW \\
\hline$*$ & Drury et al. 2017 & Whelan Exp Farm & 2013-14 & subset 3 & 0 & 14 & Clay loam & Unk & $\mathrm{C}-\mathrm{C}$ \\
\hline *§ & Woodley et al. 2018 & Whelan Exp Farm & 2013-14 & subset 3 & 0 & 6 & Clay loam & Unk & $\mathrm{C}-\mathrm{C}$ \\
\hline${ }^{* \wedge}$ & Drury et al. 2014 & Whelan Exp Farm('59) & 2007-09 & subset 3 & 0 & 6 & Clay & $\mathrm{MP}$ & $\mathrm{C}-\mathrm{C}$ \\
\hline \multicolumn{10}{|c|}{ Pennsylvania } \\
\hline & Adviento-Borbe et al. 2010-1 & R.E. Larson ARC & 2006-07 & subset 1 & 0 & 2 & Silt loam & Conv & $\mathrm{C}-\mathrm{C}$ \\
\hline & Adviento-Borbe et al. 2010-2 & R.E. Larson ARC & 2006-07 & subset 4 & 0 & 2 & Silt loam & Conv & $\mathrm{C}-\mathrm{C}$ \\
\hline & Dell et al. 2014 & R.E. Larson ARC & 2009-12 & subset 2 & 0 & 32 & Silt loam & NT & $\mathrm{C}-\mathrm{C}$ \\
\hline
\end{tabular}




\begin{tabular}{|c|c|c|c|c|c|c|c|c|c|}
\hline & Citation & Location & Year(s) & $\begin{array}{c}\text { Data } \\
\text { subset }\end{array}$ & $\begin{array}{c}\text { Model } \\
\text { dataset (\# } \\
\text { of obs.) }\end{array}$ & $\begin{array}{c}\text { Expanded } \\
\text { dataset (\# } \\
\text { of obs.) } \\
\end{array}$ & Soil texture & Tillage $^{a}$ & $\begin{array}{c}\text { Crop } \\
\text { rotation }(s)^{b}\end{array}$ \\
\hline \multicolumn{10}{|c|}{ Quebec } \\
\hline${ }^{*} \ddagger$ & Chantigny et al. 2010-1 & AAFC-Chapais & 2004-06 & subset 3 & 0 & 5 & Clay, loam & $\mathrm{MP}$ & $\mathrm{C}-\mathrm{C}$ \\
\hline${ }^{*} \ddagger$ & Chantigny et al. 2010-2 & AAFC-Chapais & 2004-06 & subset 4 & 25 & 30 & Clay, loam & $\mathrm{MP}$ & $\mathrm{C}-\mathrm{C}$ \\
\hline${ }^{*}$ & Rochette et al. 2008b & AAFC-Harlaka & 2002-03 & subset 4 & 8 & 8 & Clay, loam & rotoT & siC \\
\hline$\ddagger$ & Chantigny et al. 2013 & AAFC-Harlaka & $2006-07$ & subset 4 & 0 & 12 & Clay, silty clay & $\mathrm{MP}$ & sic \\
\hline \multirow[t]{2}{*}{ * } & Pelster et al. 2011 & AAFC-L'Acadie & 2004 & subset 3 & 4 & 6 & Clay loam & MP; NT & C-S \\
\hline & Almaraz et al. 2009 & Lods ARC - McGill & 2003 & subset 3 & 0 & 4 & Clay loam & MP; NT & $\mathrm{C}-\mathrm{C}$ \\
\hline \multicolumn{10}{|c|}{ South Dakota } \\
\hline & Lehman \& Osborne 2013 & ESD WSRF & 2008-10 & subset 3 & 0 & 8 & Sandy clay loam & NT & $\begin{array}{c}\text { C-S, C-fP- } \\
\text { WW-S }\end{array}$ \\
\hline \multicolumn{10}{|c|}{ Tennessee } \\
\hline & Thornton \& Valente 1996 & WTES & 1993 & subset 2 & 2 & 3 & Silt loam & NT & $\mathrm{C}-\mathrm{C}$ \\
\hline & Thornton et al. 1996 & WTES & 1994 & subset 2 & 0 & 3 & Silt loam & NT & $\mathrm{C}-\mathrm{C}$ \\
\hline \multicolumn{10}{|c|}{ Wisconsin } \\
\hline$\wedge$ & Osterholz et al. 2014 & Arlington Rsrch Stn & 2010-11 & subset 1 & 4 & 4 & Silt loam & Conv; CsT & $\mathrm{C}-\mathrm{C}$ \\
\hline
\end{tabular}

a Tillage abbreviations: Conv (conventional tillage, unspecified), CP (chisel plow), CsT (Conservation tillage, unspecified), Cultiv (Cultivator), D (disk), MP (moldboard plow/mouldboard plough), NT (no-till), rotoT (Rototiller or rotary plow), ST (strip till), Unk (unknown or not specified)

${ }^{b}$ Crop abbreviations: B (barley), C (corn [maize]), siC (silage corn), fP (field pea), Rg (ryegrass; [a] annual, [p] perennial), S (soybean), SF (sunflower), W (wheat), wW (winter wheat)

${ }^{c}$ Citations preceded by a + indicate that some data not available from the published research were obtained directly from study author(s).

${ }^{\mathrm{d}}$ Citations preceded by a $¥$ indicate that data (most often yield or $\mathrm{N}$ uptake) were obtained from companion publication by all or some of the same authors.

e Citations preceded by $\mathrm{a}^{\wedge}$ indicate additional maize observations are available, but they did not meet selection criteria (e.g., yield not available, experimental drainage treatment, drought year, crop rotation included alfalfa).

${ }^{f}$ Where data from a single publication fit within more than one of the data subsets (e.g., some observations on silt loam soil, others on silty clay loam soil), the publication is listed twice in this table, followed by a "1" or " 2 " to indicate the different group of data.

${ }^{\mathrm{g}}$ Citations preceded by $\mathrm{a}^{*}$ indicate that data for grain $\mathrm{N}$ or silage $\mathrm{N}$ removed were available for all or a portion of observations within these studies.

${ }^{\mathrm{h}}$ Citations preceded by $\mathrm{a}^{\S}$ indicate additional observations are available, but they are also reported in publications listed earlier in this table. For example, Cambareri et al. 2017b report some observations also reported by Cambareri et al. 2017a. These observations are only included once in our dataset. 
Table S4. Studies used or mentioned in previous agricultural $\mathrm{N}_{2} \mathrm{O}$ emission synthesis and meta-analysis studies, but out of scope or otherwise not useable for this study. These studies are listed as they are cited in previous work(s) - see these articles or their supplemental materials for full citations and further information; listed first by province (Canada), then state (USA), then by name of other countries.

\begin{tabular}{|c|c|c|c|c|c|c|c|c|c|c|c|c|c|}
\hline Reference & Reason discarded & Location & Years & 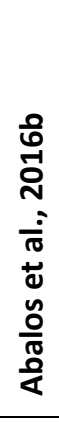 & 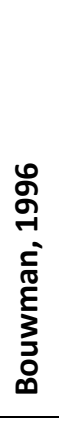 & 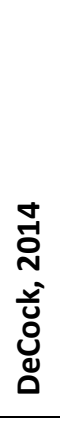 & 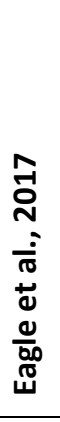 & 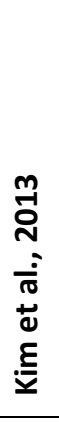 & 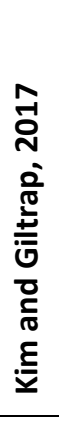 & 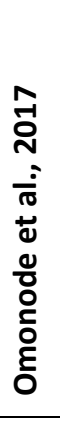 & 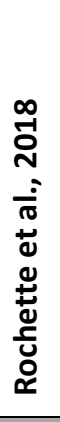 & 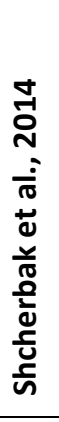 & 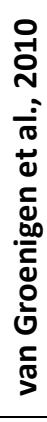 \\
\hline Lemke et al., 2007 & Legume; yield not reported & AB \& SK, Canada & 2000-03 & & & & & & & & & & \\
\hline Soon et al., 2011 & $\begin{array}{l}\mathrm{N} \text { uptake given for whole } \\
\text { plant, not harvested } \mathrm{N}\end{array}$ & AB \& SK, Canada & 2004-07 & & & & & & & & & & \\
\hline Guérin et al., (unpubl.) & Could not obtain paper/report & AB or SK, Canada & Unk & & & & & & & & & & \\
\hline Chang et al., 1998 & Yield not reported & AB, Canada & 1993-94 & & & & & & & & & & \\
\hline Lemke et al., 1999 & Yield not reported & AB, Canada & 1993-95 & & & & & & & & & & \\
\hline Lemke et al., 1998 & Yield and grain $\mathrm{N}$ not reported & AB, Canada & 1993-95 & & & & & & & & & & \\
\hline Hao et al., 2001 & Irrigated & AB, Canada & 1996-97 & & & & & & & & & & \\
\hline Ellert \& Janzen, 2008 & Irrigated & AB, Canada & 2001-03 & & & & & & & & & & \\
\hline Bhandral et al., 2008 & $\begin{array}{l}\text { Grassland; or manure applied } \\
\text { to bare soil }\end{array}$ & BC, Canada & 2001-02 & & & & & & & & & & \\
\hline Bhandral et al., 2009 & Grassland & BC, Canada & 2005-06 & & & & & & & & & & \\
\hline Burton et al., 2008 & $\begin{array}{l}\text { Yield and } \mathrm{N} \text { uptake not } \\
\text { reported }\end{array}$ & MB, Canada & 2000-02 & & & & & & & & & & \\
\hline Tenuta et al., 2010 & Grassland & MB, Canada & 2004-06 & & & & & & & & & & \\
\hline Gao et al., 2013 & $\mathrm{~N}$ harvested not reported & MB, Canada & 2009-10 & & & & & & & & & & \\
\hline Burton et al., 2008 & $\begin{array}{l}\mathrm{N} \text { uptake given for whole } \\
\text { plant, not harvested } \mathrm{N}\end{array}$ & NB, Canada & 2002-03 & & & & & & & & & & \\
\hline Zebarth et al., 2008 & $\mathrm{~N}$ uptake not reported & NB, Canada & 2003-05 & & & & & & & & & & \\
\hline
\end{tabular}




\begin{tabular}{|c|c|c|c|c|c|c|c|c|c|c|c|c|c|}
\hline Reference & Reason discarded & Location & Years & 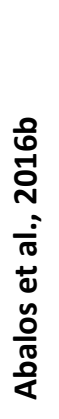 & 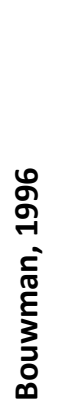 & 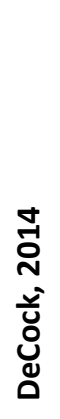 & 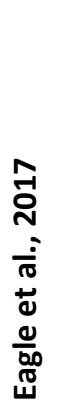 & 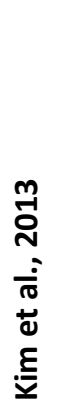 & 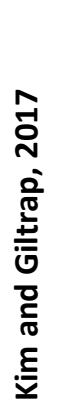 & 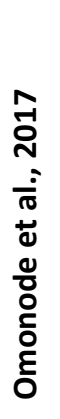 & 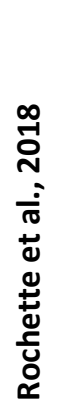 & 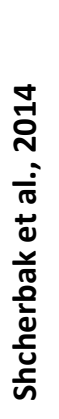 & 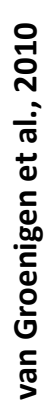 \\
\hline Zebarth et al., 2008 & $\begin{array}{l}\text { Yield avg of all treatments; } \\
\text { prior manure application; } \mathrm{N} \\
\text { uptake is whole plant }\end{array}$ & NB, Canada & 2004-05 & & & & & & & & & & \\
\hline Ma et al., 2010 & $\begin{array}{l}\text { N2O measured for only } 28 \\
\text { days; yield avg across years } \\
\text { and sites }\end{array}$ & ON \& QC, Canada & 2005-07 & & & & & & & & & & \\
\hline Lessard et al., 1996 & Yield not reported & ON, Canada & 1993 & & & & & & & & & & \\
\hline Bergstrom et al., 2001 & Perennial crop & ON, Canada & 1993 & & & & & & & & & & \\
\hline $\begin{array}{l}\text { Wagner-Riddle et al., } \\
1997\end{array}$ & Yield not reported & ON, Canada & 1994 & & & & & & & & & & \\
\hline $\begin{array}{l}\text { Tenuta \& Beauchamp, } \\
2003\end{array}$ & $\begin{array}{l}\text { N2O measured for only } 21 \\
\text { days; no crop grown }\end{array}$ & ON, Canada & 1994 & & & & & & & & & & \\
\hline Kaharabata et al., 2003 & $\begin{array}{l}\mathrm{N} 2 \mathrm{O} \text { and } \mathrm{N} \text { uptake values not } \\
\text { from same years }\end{array}$ & ON, Canada & 1995 & & & & & & & & & & \\
\hline Grant \& Pattey, 2003 & $\begin{array}{l}\text { N2O measured for only } 40 \\
\text { days }\end{array}$ & ON, Canada & 1998 & & & & & & & & & & \\
\hline McKenney et al., 1980 & Yield not reported & ON, Canada & $1978-79$ & & & & & & & & & & \\
\hline $\begin{array}{l}\text { Wagner-Riddle \& } \\
\text { Thurtell, } 1998\end{array}$ & Yield not reported & ON, Canada & 1993-96 & & & & & & & & & & \\
\hline Maggiotto et al., 2000 & Turfgrass & ON, Canada & 1995-97 & & & & & & & & & & \\
\hline Gregorich et al., 2008 & Yield not reported & ON, Canada & $2003-05$ & & & & & & & & & & \\
\hline Drury et al., 2008 & Yield not reported & ON, Canada & $2003-05$ & & & & & & & & & & \\
\hline $\begin{array}{l}\text { Kariyapperuma et al., } \\
2012\end{array}$ & $\begin{array}{l}\text { N2O only for non-growing } \\
\text { season }\end{array}$ & ON, Canada & 2005-06 & & & & & & & & & & \\
\hline
\end{tabular}




\begin{tabular}{|c|c|c|c|c|c|c|c|c|c|c|c|c|c|}
\hline Reference & Reason discarded & Location & Years & 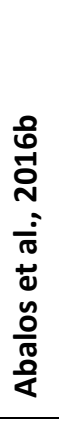 & 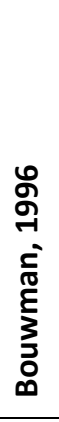 & 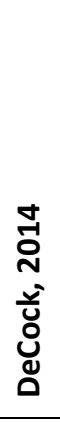 & 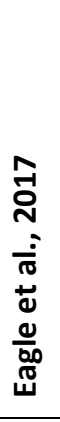 & 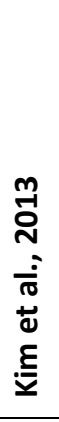 & 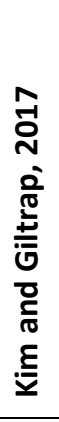 & 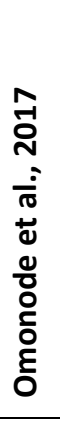 & 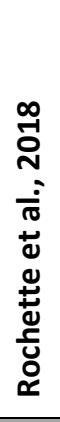 & 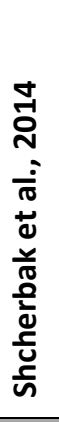 & 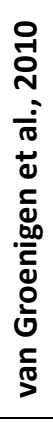 \\
\hline MacKenzie et al., 1997 & Yield not reported & QC, Canada & 1994 & & & & & & & & & & \\
\hline Fan et al., 1997 & Yield not reported & QC, Canada & 1994 & & & & & & & & & & \\
\hline Rochette et al., 2004 & $\begin{array}{l}\text { Yield and } \mathrm{N} \text { uptake not } \\
\text { reported }\end{array}$ & QC, Canada & 1999 & & & & & & & & & & \\
\hline MacKenzie et al., 1998 & Yield not reported & QC, Canada & 1994-95 & & & & & & & & & & \\
\hline Rochette et al., 2000 & $\begin{array}{l}\text { Yield reported is averaged } \\
\text { over } 1990-1995 \text { and } \mathrm{N} 20 \text { is } \\
\text { from } 1997-1998\end{array}$ & QC, Canada & 1997-98 & & & & & & & & & & \\
\hline Rochette et al., 2004 & Legume and perennial crops & QC, Canada & 2001-02 & & & & & & & & & & \\
\hline Chantigny et al., 2007 & $\begin{array}{l}\text { N2O measured for only } 42 \\
\text { days }\end{array}$ & QC, Canada & 2001-03 & & & & & & & & & & \\
\hline Rochette et al., 2008 & Yield and grain $\mathrm{N}$ not reported & QC, Canada & 2001-03 & & & & & & & & & & \\
\hline Elmi et al., 2009 & Yield not reported & QC, Canada & 2003-04 & & & & & & & & & & \\
\hline Pattey et al., 2008 & Legume & QC, Canada & 2003-04 & & & & & & & & & & \\
\hline Gagnon et al., 2011 & $\begin{array}{l}\text { Study follows long-term grass } \\
\text { meadow }\end{array}$ & QC, Canada & 2004-06 & & & & & & & & & & \\
\hline MacDonald et al., 2011 & Grassland & QC, Canada & 2007-08 & & & & & & & & & & \\
\hline Corre et al., 1999 & Yield and grain $\mathrm{N}$ not reported & SK, Canada & 1993-95 & & & & & & & & & & \\
\hline Lemke et al., (unpubl.) & Could not obtain paper/report & SK, Canada & 1999-2004 & & & & & & & & & & \\
\hline Mahli et al., 2006 & $\begin{array}{l}\text { Data averaged across tillage } \\
\text { and residue treatments }\end{array}$ & SK, Canada & 2000-01 & & & & & & & & & & \\
\hline Malhi \& Lemke, 2007 & $\begin{array}{l}\text { Data averaged across } \\
\text { treatments }\end{array}$ & SK, Canada & $2002-05$ & & & & & & & & & & \\
\hline
\end{tabular}




\begin{tabular}{|c|c|c|c|c|c|c|c|c|c|c|c|c|c|}
\hline Reference & Reason discarded & Location & Years & 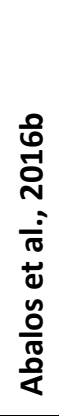 & 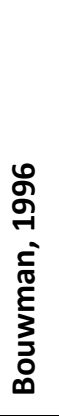 & 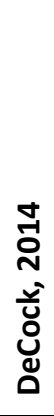 & 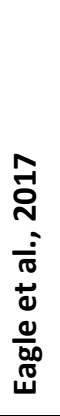 & 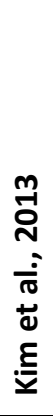 & 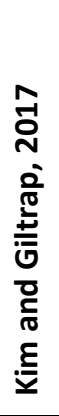 & 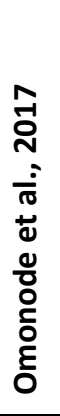 & 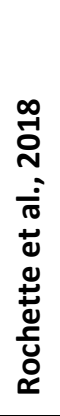 & 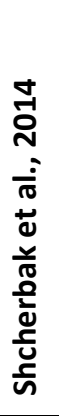 & 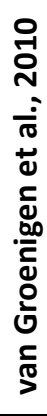 \\
\hline Mahli et al., 2009 & $\begin{array}{l}\mathrm{N} 2 \mathrm{O} \text { average over multiple } \mathrm{N} \\
\text { rates }\end{array}$ & SK, Canada & 2003-07 & & & & & & & & & & \\
\hline Pennock \& Corre, 2001 & Yield and grain $\mathrm{N}$ not reported & SK, Canada & 2006-07 & & & & & & & & & & \\
\hline Pittelkow et al., 2013 & Irrigated rice & CA, USA & 2010-12 & & & & & & & & & & \\
\hline $\begin{array}{l}\text { Adviento-Borbe et al., } \\
2013\end{array}$ & Irrigated rice & CA, USA & 2010-12 & & & & & & & & & & \\
\hline $\begin{array}{l}\text { Mosier \& Hutchinson, } \\
1981\end{array}$ & Yield not reported & CO, USA & 1978 & & & & & & & & & & \\
\hline $\begin{array}{l}\text { Hutchinson \& Mosier, } \\
1979\end{array}$ & Irrigated & CO, USA & 1978 & & & & & & & & & & \\
\hline Mosier et al., 1986 & Irrigated & CO, USA & $1982-83$ & & & & & & & & & & \\
\hline Bronson et al., 1992 & Irrigated & CO, USA & 1989-90 & & & & & & & & & & \\
\hline Delgado \& Mosier 1996 & Irrigated & CO, USA & 1993 & & & & & & & & & & \\
\hline Mosier et al., 2006 & Irrigated & CO, USA & 2002-04 & & & & & & & & & & \\
\hline Liu et al., 2005 & Data in Mosier et al., 2006 & CO, USA & 2003-04 & & & & & & & & & & \\
\hline Halvorson et al., 2008 & Irrigated & CO, USA & 2005-06 & & & & & & & & & & \\
\hline Halvorson et al., 2010 & Irrigated & CO, USA & 2007-08 & & & & & & & & & & \\
\hline Halvorson et al., 2010 & Irrigated & CO, USA & 2007-08 & & & & & & & & & & \\
\hline $\begin{array}{l}\text { Halvorson \& Del } \\
\text { Grosso, } 2012\end{array}$ & Irrigated & CO, USA & 2009-10 & & & & & & & & & & \\
\hline Halvorson et al., 2011 & Irrigated & CO, USA & 2009-10 & & & & & & & & & & \\
\hline $\begin{array}{l}\text { Halvorson \& Del } \\
\text { Grosso, } 2013\end{array}$ & Irrigated & CO, USA & 2010-11 & & & & & & & & & & \\
\hline
\end{tabular}




\begin{tabular}{|c|c|c|c|c|c|c|c|c|c|c|c|c|c|}
\hline Reference & Reason discarded & Location & Years & 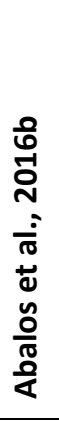 & 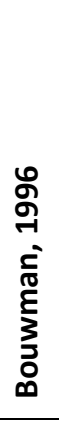 & 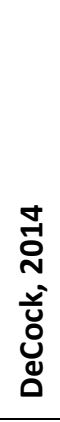 & 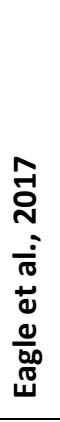 & 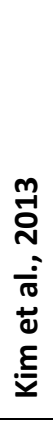 & 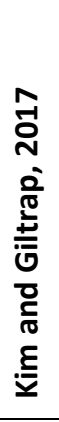 & 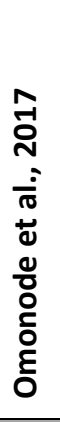 & 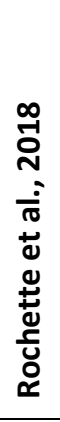 & 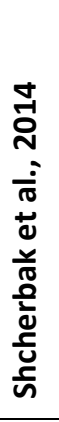 & 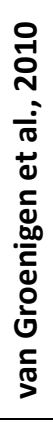 \\
\hline Halvorson et al., 2016 & Irrigated & CO, USA & 2012-14 & & & & & & & & & & \\
\hline Lowrance et al., 1998 & $\begin{array}{l}\mathrm{N} 2 \mathrm{O} \text { and } \mathrm{N} \text { uptake from diff. } \\
\text { years }\end{array}$ & GA, USA & 1990-93 & & & & & & & & & & \\
\hline $\begin{array}{l}\text { Breitenbeck \& } \\
\text { Bremner, } 1986\end{array}$ & No crop grown & IA, USA & 1979 & & & & & & & & & & \\
\hline Parkin \& Kaspar, 2006 & $\begin{array}{l}\text { Yield averaged across years, } \\
\text { and } \mathrm{N} \text { uptake not reported }\end{array}$ & IA, USA & 2003-04 & & & & & & & & & & \\
\hline Jarecki et al., 2009 & $\begin{array}{l}\text { Yield averaged over } 2006 \& \\
2007 \text { but } \mathrm{N} 20 \text { is only from } \\
2006\end{array}$ & IA, USA & 2006 & & & & & & & & & & \\
\hline Jarecki et al., 2008 & Yield not reported & IA, USA & 2006 & & & & & & & & & & \\
\hline Mitchell et al., 2013 & Same data as Iqbal et al., 2015 & IA, USA & 2011 & & & & & & & & & & \\
\hline Omonode \& Vyn, 2013 & Yield not reported & IN, USA & 2011-12 & & & & & & & & & & \\
\hline Sistani et al., 2010 & Yield not reported & KY, USA & 2007-08 & & & & & & & & & & \\
\hline Smith et al., 1982 & $\begin{array}{l}\text { Grain N not reported; } \\
\text { Irrigated }\end{array}$ & LA, USA & 1980 & & & & & & & & & & \\
\hline Venterea et al., 2003 & Forest & MA, USA & 2000-01 & & & & & & & & & & \\
\hline Grandy et al., 2006 & $\begin{array}{l}\text { Cumulative } \mathrm{N} 2 \mathrm{O} \text { averaged } \\
\text { across years; } \mathrm{N} \text { uptake not } \\
\text { reported }\end{array}$ & MI, USA & 1989-2002 & & & & & & & & & & \\
\hline $\begin{array}{l}\text { McSwiney \& } \\
\text { Robertson, } 2005\end{array}$ & $\begin{array}{l}\text { Irrigated in 2003; short } \mathrm{N} 2 \mathrm{O} \\
\text { measurement period in } 2001- \\
02\end{array}$ & MI, USA & 2001-2003 & & & & & & & & & & \\
\hline Venterea et al., 2005 & Yield not reported & MN, USA & 2003-04 & & & & & & & & & & \\
\hline
\end{tabular}




\begin{tabular}{|c|c|c|c|c|c|c|c|c|c|c|c|c|c|}
\hline Reference & Reason discarded & Location & Years & 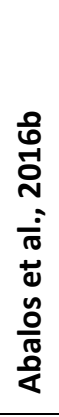 & 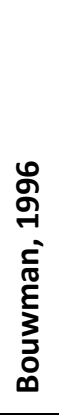 & 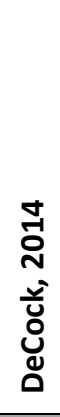 & 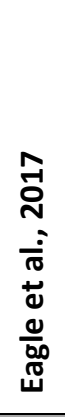 & 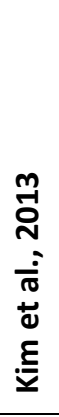 & 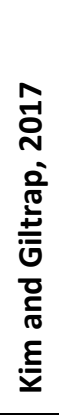 & 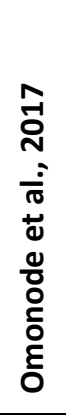 & 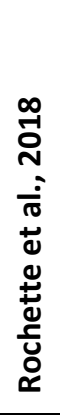 & 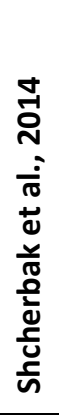 & 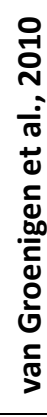 \\
\hline Johnson et al., 2010 & Yield not reported & MN, USA & 2004-06 & & & & & & & & & & \\
\hline Bavin et al., 2009 & Yield not reported & MN, USA & 2005 & & & & & & & & & & \\
\hline Fujinuma et al., 2011 & Irrigated & MN, USA & 2009-10 & & & & & & & & & & \\
\hline Maharjan et al., 2014 & $\begin{array}{l}\text { Some observations irrigated } \\
\text { and rainfed observations had } \\
\text { poor yields }\end{array}$ & MN, USA & 2009-10 & & & & & & & & & & \\
\hline Paniagua, 2006 & $\begin{array}{l}\text { Not peer-reviewed; N uptake } \\
\text { not reported; } \mathrm{N} 2 \mathrm{O} \text { for only } \\
\text { one } \mathrm{N} \text { rate }\end{array}$ & MO, USA & 2004-05 & & & & & & & & & & \\
\hline Nash et al., 2012 & Irrigated & MO, USA & $2009-10$ & & & & & & & & & & \\
\hline Dusenbury et al., 2008 & $\begin{array}{l}\mathrm{N} \text { harvested reported as total } \\
\text { of three cropping seasons }\end{array}$ & MT, USA & 2004-06 & & & & & & & & & & \\
\hline Qian et al., 1997 & Irrigated & NE, USA & 1991-92 & & & & & & & & & & \\
\hline $\begin{array}{l}\text { Adviento-Borbe et al., } \\
2007\end{array}$ & Irrigated & NE, USA & 2003-05 & & & & & & & & & & \\
\hline Jin et al., 2017 & Irrigated & NE, USA & 2011-15 & & & & & & & & & & \\
\hline $\begin{array}{l}\text { Duxbury \& } \\
\text { McConnaughey, } 1986\end{array}$ & Yield not reported & NY, USA & 1981 & & & & & & & & & & \\
\hline Duxbury et al., 1982 & Yield not reported & NY, USA & $1979-80$ & & & & & & & & & & \\
\hline Ussiri et al., 2009 & Yield not reported & $\mathrm{OH}$, USA & 2005 & & & & & & & & & & \\
\hline Jacinthe \& Dick, 1997 & Yield not reported & $\mathrm{OH}$, USA & 1993-94 & & & & & & & & & & \\
\hline Goodroad et al., 1984 & Yield not reported & WI, USA & 1979-81 & & & & & & & & & & \\
\hline
\end{tabular}




\begin{tabular}{|c|c|c|c|c|c|c|c|c|c|c|c|c|c|}
\hline Reference & Reason discarded & Location & Years & 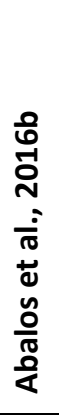 & 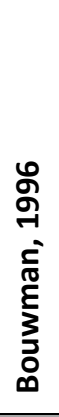 & 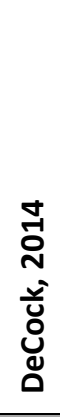 & 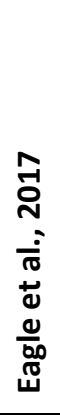 & 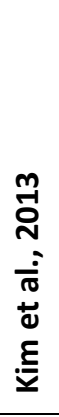 & 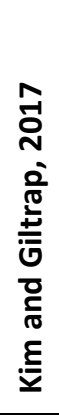 & 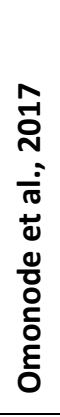 & 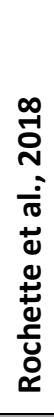 & 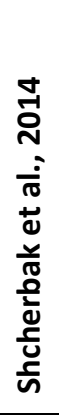 & 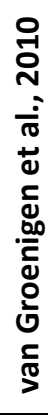 \\
\hline Cates \& Keeney, 1987 & $\begin{array}{l}\text { Yield not reported; location } \\
\text { not specified }\end{array}$ & WI, USA & 1981 & & & & & & & & & & \\
\hline Ciampitti et al., 2005 & $\begin{array}{l}\text { Bare soil and soybean } \\
\text { treatments }\end{array}$ & Argentina & 2004-05 & & & & & & & & & & \\
\hline Allen et al., 2010 & Sugarcane (perennial) & Australia & 2003-04 & & & & & & & & & & \\
\hline Signor et al., 2013 & $\begin{array}{l}\text { Sugarcane (perennial); N2O } \\
\text { only measured for } 16 \& 50 \\
\text { days }\end{array}$ & Brazil & 2009-10 & & & & & & & & & & \\
\hline Jankowski et al., 2018 & Tropical location & Brazil & 2015 & & & & & & & & & & \\
\hline Chiaradia et al., 2009 & $\begin{array}{l}\text { Sewage sludge study; N2O } \\
\text { only measured for } 21 \text { days }\end{array}$ & Brazil & Unk & & & & & & & & & & \\
\hline Bruemmer et al., 2008 & Tropical location & Burkina Faso & 2005-06 & & & & & & & & & & \\
\hline Cai et al., 1997 & Irrigated rice & China & 1994 & & & & & & & & & & \\
\hline Zou et al., 2005 & Irrigated rice & China & 2002-03 & & & & & & & & & & \\
\hline Huang et al., 2005 & Irrigated rice & China & 2003 & & & & & & & & & & \\
\hline Dong et al., 2005 & Yield not reported & China & 2003 & & & & & & & & & & \\
\hline Ma et al., 2007 & Irrigated rice & China & 2003-05 & & & & & & & & & & \\
\hline Zhao et al., 2009 & $\begin{array}{l}\text { Irrigated rice; Grain N not } \\
\text { reported }\end{array}$ & China & 2004 & & & & & & & & & & \\
\hline Ding et al., 2007 & Yield not reported & China & 2004-05 & & & & & & & & & & \\
\hline Zhou et al., 2013 & Yield not reported & China & 2004-07 & & & & & & & & & & \\
\hline Song \& Zhang, 2009 & Yield not reported & China & 2005 & & & & & & & & & & \\
\hline
\end{tabular}




\begin{tabular}{|c|c|c|c|c|c|c|c|c|c|c|c|c|c|}
\hline Reference & Reason discarded & Location & Years & 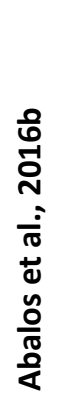 & 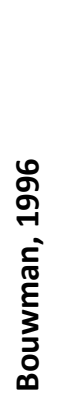 & 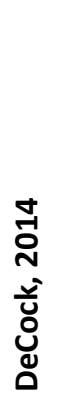 & 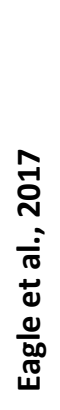 & 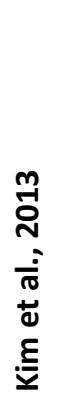 & 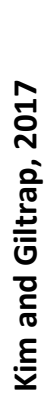 & 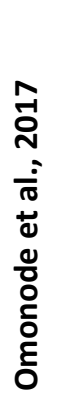 & 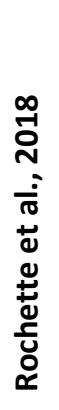 & 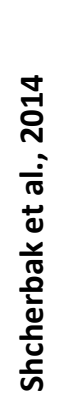 & 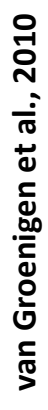 \\
\hline Zhang \& Han, 2008 & $\begin{array}{l}\text { Grassland and abandoned } \\
\text { farmland }\end{array}$ & China & 2005 & & & & & & & & & & \\
\hline $\begin{array}{l}\text { Zhang et al., } 2007 \\
\text { [Zhang and Han 2008] }\end{array}$ & $\begin{array}{l}\text { Grassland and abandoned } \\
\text { farmland }\end{array}$ & China & 2005-06 & & & & & & & & & & \\
\hline Yao et al., 2012 & Irrigated rice & China & 2005-07 & & & & & & & & & & \\
\hline Liang et al., 2013 & Irrigated rice & China & $2005-10$ & & & & & & & & & & \\
\hline Wang et al., 2011 & Irrigated rice & China & 2006 & & & & & & & & & & \\
\hline Lin et al., 2011 & Yield not reported & China & $2006-07$ & & & & & & & & & & \\
\hline Iqbal 2009 & Irrigated rice & China & 2007 & & & & & & & & & & \\
\hline Min et al., 2012 & Greenhouse experiment & China & $2007-08$ & & & & & & & & & & \\
\hline Qin et al., 2012 & Irrigated & China & 2007-09 & & & & & & & & & & \\
\hline Lou et al., 2012 & Greenhouse vegetables & China & 2008 & & & & & & & & & & \\
\hline Ji et al., 2012 & Grain N not reported & China & 2009-10 & & & & & & & & & & \\
\hline Ma et al., 2013 & Irrigated rice & China & 2009-11 & & & & & & & & & & \\
\hline Liu et al., 2012 & Irrigated & China & 2010 & & & & & & & & & & \\
\hline Xia et al., 2016 & Irrigated rice & China & 2013-14 & & & & & & & & & & \\
\hline Liu et al., 2004 & Could not obtain paper & China & Unk & & & & & & & & & & \\
\hline Xiang et al., 2007 & $\begin{array}{l}\text { Could not obtain paper } \\
\text { (Chinese with English } \\
\text { abstract) }\end{array}$ & China & Unk & & & & & & & & & & \\
\hline Henault et al., 1998 & Yield not reported & France & 1994-95 & & & & & & & & & & \\
\hline Augustin et al., 1998 & Not agriculture, peat fens & Germany & 1995 & & & & & & & & & & \\
\hline
\end{tabular}




\begin{tabular}{|c|c|c|c|c|c|c|c|c|c|c|c|c|c|}
\hline Reference & Reason discarded & Location & Years & 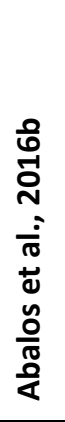 & 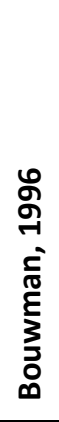 & 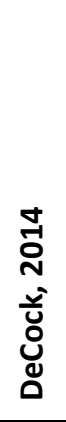 & 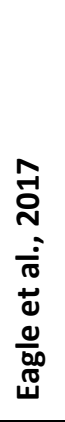 & 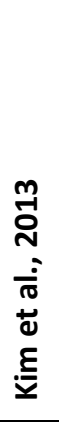 & 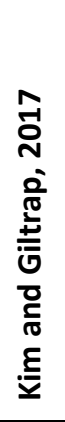 & 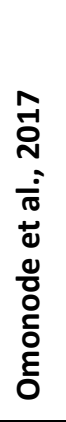 & 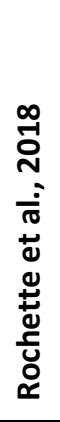 & 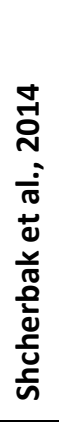 & 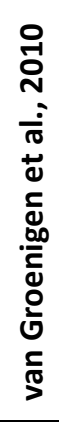 \\
\hline Ruser et al., 2001 & $\mathrm{~N} 2 \mathrm{O}$ averaged over 2 years & Germany & 1995-96 & & & & & & & & & & \\
\hline Hoffman et al., 2001 & Grassland & Germany & 1995-98 & & & & & & & & & & \\
\hline Kammann et al., 1998 & Grassland & Germany & 1996-97 & & & & & & & & & & \\
\hline Anger et al., 2003 & Grassland & Germany & $1997-98$ & & & & & & & & & & \\
\hline Kavdir et al., 2008 & Yield not reported & Germany & 2003-05 & & & & & & & & & & \\
\hline Kern et al., 2008 & $\begin{array}{l}\text { Not peer-reviewed; could not } \\
\text { obtain paper/report }\end{array}$ & Germany & Unk & & & & & & & & & & \\
\hline Lampe et al., 2008 & $\begin{array}{l}\text { Grassland; could not obtain } \\
\text { paper/report }\end{array}$ & Germany & Unk & & & & & & & & & & \\
\hline Suratno et al., 1998 & Tropical location & Indonesia & 1995 & & & & & & & & & & \\
\hline Hyde et al., 2006 & Grassland & Ireland & $2002-03$ & & & & & & & & & & \\
\hline Kim et al., 2010 & Grassland & Ireland & $\begin{array}{l}2003-05 \\
2007-08\end{array}$ & & & & & & & & & & \\
\hline Abdalla et al., 2010 & $\mathrm{~N}$ uptake not reported & Ireland & 2004-05 & & & & & & & & & & \\
\hline Kusa et al., 2002 & $\begin{array}{l}\text { Unclear if } \mathrm{N} \text { uptake is } \mathrm{N} \\
\text { harvested or total biomass }\end{array}$ & Japan & 1995-2000 & & & & & & & & & & \\
\hline Yan et al., 2001 & $\begin{array}{l}\text { Corn was transplanted; also, } \\
\text { yield and } \mathrm{N} \text { uptake values } \\
\text { unclear }\end{array}$ & Japan & 1999 & & & & & & & & & & \\
\hline Cheng et al., 2002 & $\mathrm{~N}$ uptake not reported & Japan & 2000 & & & & & & & & & & \\
\hline Li et al., 2002 & $\begin{array}{l}\text { Irrigated and yield not } \\
\text { reported }\end{array}$ & Japan & 2000 & & & & & & & & & & \\
\hline
\end{tabular}




\begin{tabular}{|c|c|c|c|c|c|c|c|c|c|c|c|c|c|}
\hline Reference & Reason discarded & Location & Years & 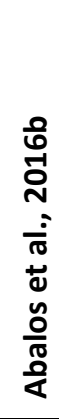 & 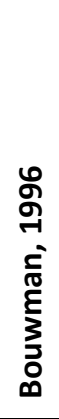 & 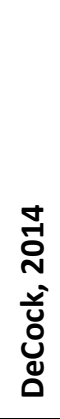 & 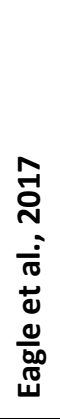 & 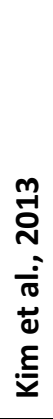 & 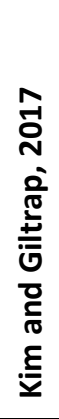 & 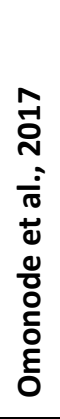 & 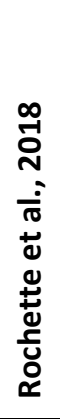 & 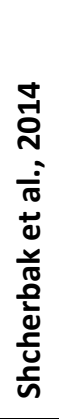 & 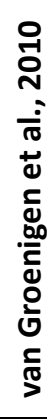 \\
\hline Mori \& Hojito, 2011 & Grassland; manure applied & Japan & 2006-08 & & & & & & & & & & \\
\hline $\begin{array}{l}\text { Balezentiene \& Kusta, } \\
2012\end{array}$ & Grassland & Lithuania & 2009 & & & & & & & & & & \\
\hline $\begin{array}{l}\text { Fernández-Luqueño et } \\
\text { al., } 2009\end{array}$ & Greenhouse experiment & Mexico & 2007-08 & & & & & & & & & & \\
\hline Velthof et al., 1996 & Perennial crop & Netherlands & $1992-94$ & & & & & & & & & & \\
\hline Velthof et al., 1996 & Grassland & Netherlands & 1993-94 & & & & & & & & & & \\
\hline Schils et al., 2008 & Perennial crop & Netherlands & $2001-02$ & & & & & & & & & & \\
\hline $\begin{array}{l}\text { van Groenigen et al., } \\
2005\end{array}$ & $\begin{array}{l}\text { Unclear if } \mathrm{N} \text { uptake is tubers } \\
\text { or total biomass }\end{array}$ & Netherlands & $2002-03$ & & & & & & & & & & \\
\hline Velthof et al., 2011 & $\begin{array}{l}\mathrm{N} \text { uptake not reported; } \\
\text { manure applied }\end{array}$ & Netherlands & 2007-09 & & & & & & & & & & \\
\hline Letica et al., 2010 & Grassland & New Zealand & 2006 & & & & & & & & & & \\
\hline van der Weerden 2000 & Irrigated & New Zealand & 1997-98 & & & & & & & & & & \\
\hline $\begin{array}{l}\text { Hoogendoorn et al., } \\
2008\end{array}$ & Grassland & New Zealand & 2005-06 & & & & & & & & & & \\
\hline Khan et al., 2010 & Grassland; not peer-reviewed & New Zealand & Unk & & & & & & & & & & \\
\hline Hansen et al., 1993 & Perennial crops & Norway & 1991 & & & & & & & & & & \\
\hline Sitaula et al., 1995 & Pine forest & Norway & 1992 & & & & & & & & & & \\
\hline Cardenas et al., 2010 & Grassland & UK & $2006-08$ & & & & & & & & & & \\
\hline Bell et al., 2015 & Grain N not reported & UK & $2011-12$ & & & & & & & & & & \\
\hline Hinton et al., 2015 & Grain N not reported & UK & 2011-12 & & & & & & & & & & \\
\hline Bell et al., 2016 & Grassland & UK & 2011-12 & & & & & & & & & & \\
\hline
\end{tabular}




\begin{tabular}{|c|c|c|c|c|c|c|c|c|c|c|c|c|c|}
\hline Reference & Reason discarded & Location & Years & 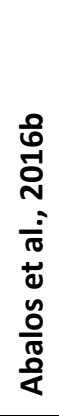 & 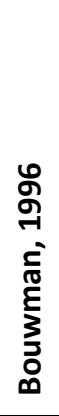 & 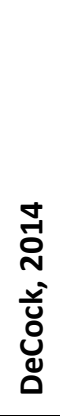 & 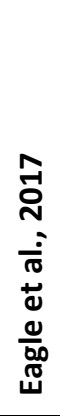 & 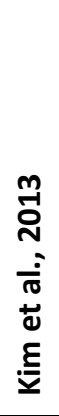 & 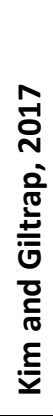 & 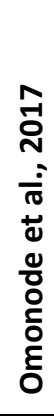 & 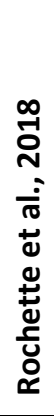 & 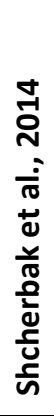 & 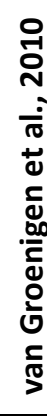 \\
\hline Bell et al., 2016 & $\mathrm{~N}$ uptake not reported & UK & $2012-13$ & & & & & & & & & & \\
\hline Ryden, 1983 & Grassland & UK & Unk & & & & & & & & & & \\
\hline Harrison et al., 1993 & $\begin{array}{l}\text { N2O only measured for } 25 \\
\text { days }\end{array}$ & UK & Unk & & & & & & & & & & \\
\hline
\end{tabular}

